\title{
e norden
}

\section{Europe and the Nordic Collective-Bargaining Model}

The Complex Interaction between Nordic and European Labour Law

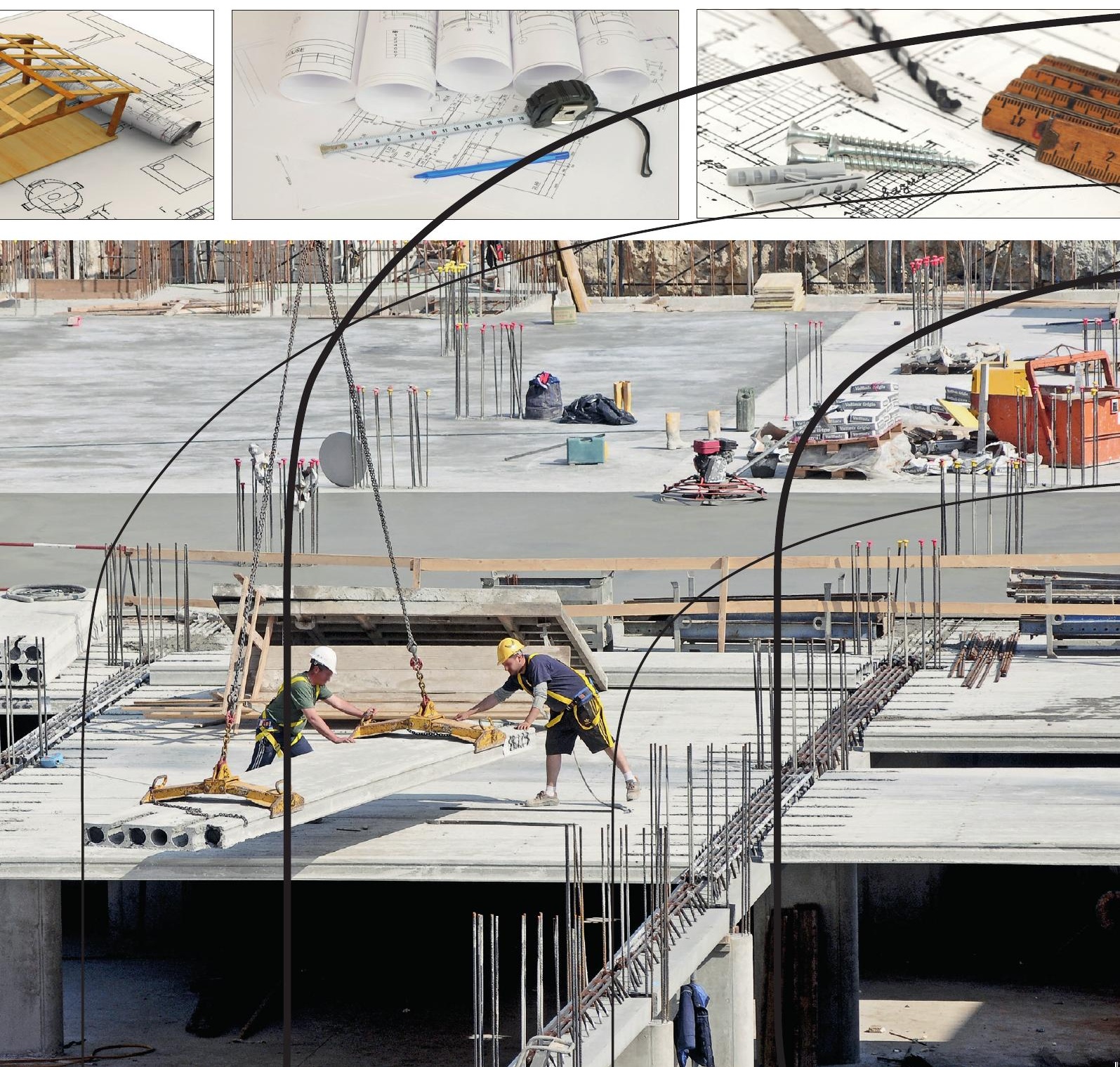



IIIIII norden 



\section{Europe and the Nordic Collective-Bargaining Model}

The Complex Interaction between Nordic and European Labour Law

Dr. Jur. Jens Kristiansen (ed.)

Contributions by:

Jens Kristiansen, Hans Tilly, Lena Maier Söderberg,

Flemming Dreesen, Magnús Norðdahl, Christen

Horn Johannessen, Hrafnhildur Stefánsdóttir,

Gabriella Sebardt, Ane Kristine Lorentzen, Jari Hellsten, Jens Kragh og Ella Sjödin

TemaNord 2015:541 
Europe and the Nordic Collective-Bargaining Model

The Complex Interaction between Nordic and European Labour Law

Dr. Jur. Jens Kristiansen (ed.)

Contributions by:

Jens Kristiansen, Hans Tilly, Lena Maier Söderberg, Flemming Dreesen, Magnús Norðdahl,

Christen Horn Johannessen, Hrafnhildur Stefánsdóttir, Gabriella Sebardt, Ane Kristine Lorentzen,

Jari Hellsten, Jens Kragh og Ella Sjödin

ISBN 978-92-893-4177-6 (PRINT)

ISBN 978-92-893-4179-0 (PDF)

ISBN 978-92-893-4178-3 (EPUB)

http://dx.doi.org/10.6027/TN2015-541

TemaNord 2015:541

ISSN 0908-6692

(C) Nordic Council of Ministers 2015

Layout: Hanne Lebech

Cover photo: ImageSelect

Print: Rosendahls-Schultz Grafisk

Copies: 1.000

Printed in Denmark

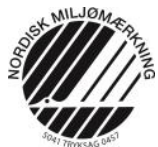

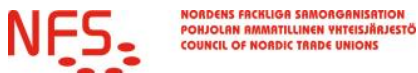

This publication has been published with financial support by the Nordic Council of Ministers. The authors of this publication are responsible for its content and conclusions, and they do not necessarily reflect the views, policies or recommendations of the Nordic Council of Ministers.

\section{www.norden.org/nordpub}

\section{Nordic co-operation}

Nordic co-operation is one of the world's most extensive forms of regional collaboration, involving Denmark, Finland, Iceland, Norway, Sweden, and the Faroe Islands, Greenland, and Åland.

Nordic co-operation has firm traditions in politics, the economy, and culture. It plays an important role in European and international collaboration, and aims at creating a strong Nordic community in a strong Europe.

Nordic co-operation seeks to safeguard Nordic and regional interests and principles in the global community. Common Nordic values help the region solidify its position as one of the world's most innovative and competitive.

\section{Nordic Council of Ministers}

Ved Stranden 18

DK-1061 Copenhagen $\mathrm{K}$

Phone (+45) 33960200

\section{www.norden.org}




\section{Content}

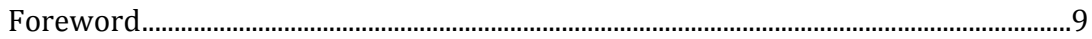

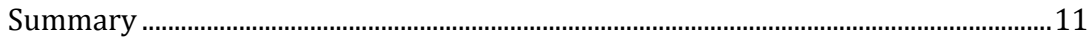

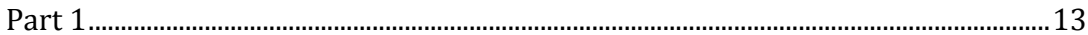

1. European Challenges of the Nordic Collective-Agreement Model

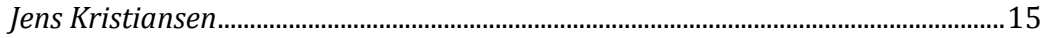

1.1 Introduction.......................................................................................................15

1.2 The Nordic collective-agreement model in a European

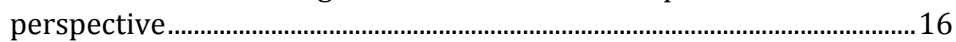

1.3 Free movement within the Internal Market.................................................22

$1.4 \quad$ Fundamental rights in working life ..................................................................

1.5 Harmonisation of wages and working conditions........................................47

$1.6 \quad$ Flexicurity as an employment policy guideline............................................63

1.7 General development trends in European influence....................................68

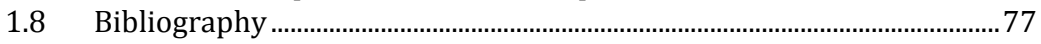

Part 2

1. Altered Labour Market after Vaxholm

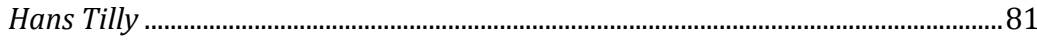

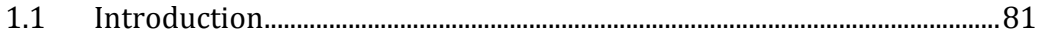

1.2 The LO (Swedish Trade Union Confederation) and the Social Democrats................................................................................................................. 82

$1.3 \quad$ The position of different parties ......................................................................84

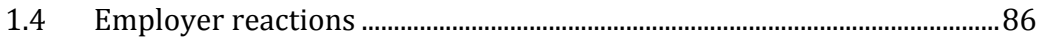

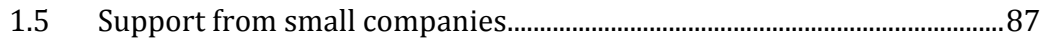

1.6 Europe, the trade union and Riksdagen........................................................... 88

$1.7 \quad$ Altered labour market..........................................................................................89

1.8 What could we have done differently? ..........................................................91

$1.9 \quad$ What is the current situation? ………………..............................................93 
2. Laval, the Swedish System of Collective Bargaining and Professionals

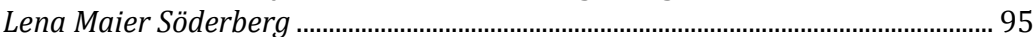

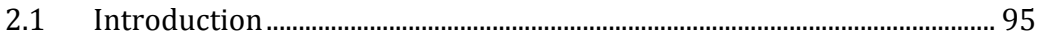

2.2 Does the Laval judgment really have an impact on Saco and

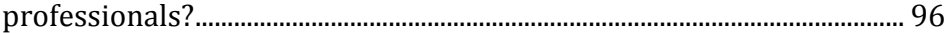

2.3 Decentralisation versus centralisation...................................................... 98

2.4 Which model for extending terms and conditions - a fourth way?....100

$2.5 \quad$ Which path did Sweden take? ...................................................................104

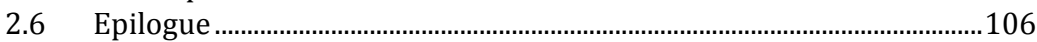

3. Danish RUT Register

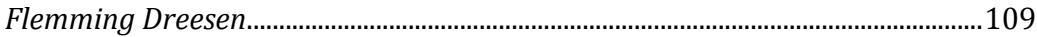

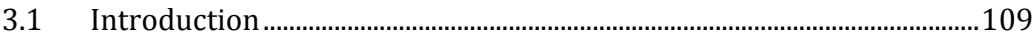

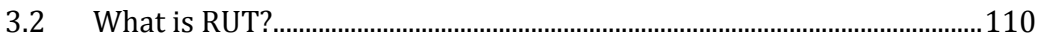

3.3 Outline of the development of RUT .........................................................113

3.4 The legal basis in European law for RUT …................................................114

3.5 The Enforcement Directive........................................................................117

3.6 Registration systems in other States, including Nordic countries ......119

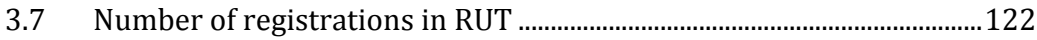

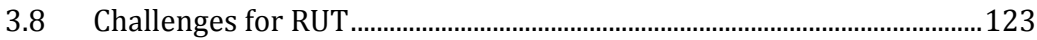

4. The Nordic Model and the EU: Implementation of Directive 96/71/EC the Icelandic Experience

Magnús Norðdahl ........................................................................................125

4.1 Is there such a thing as one Nordic model? ..........................................125

4.2 EEA law and national legislation.............................................................127

4.3 Implementation of Directive 96/71/EC in Iceland..................................130

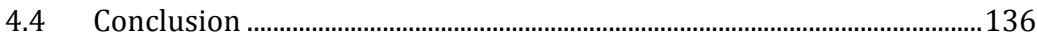

5. Does EU legislation Enable Airlines to Discard the Nordic LabourMarket Model?

Christen Horn Johannessen

5.1 The Nordic labour-market model is sustainable and defensible.........139

5.2 It is possible to use industrial action to preserve operations that are the basis for the collective agreement

5.3 The "Flying Dutchmen of labour law" - cause for deep concern .........146

5.4 EU law does not protect fair competition and fundamental rights ....151

6. Collective Bargaining, Freedom of Association and the Impact of the EEA Agreement on Icelandic Labour Law

Hrafnhildur Stefánsdóttir

6.1 Collective bargaining in Iceland and cooperation between the social partners.

6.2 Freedom of association and priority clauses in collective agreements

6.3 Influence of the EEA Agreement and the implementation of Labour Law Directives. 
7. Last in, First out? The Agency Work Directive and the Swedish Staffing Industry as Part of the Swedish Labour-Market Model

Gabriella Sebardt..

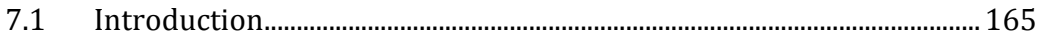

7.2 The Staffing Industry in the Swedish Model ............................................ 166

7.3 The Implementation of the Agency Work Directive in Sweden...........169

$7.4 \quad$ Threats and Opportunities ....................................................................177

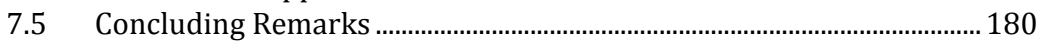

7.6 Bibliography ........................................................................................... 181

8. The Role of the Implementation Committee in Denmark with focus on the Temporary Agency Work Directive

Ane Kristine Lorentzen

8.1 Basis for the implementation of Directives in the field of labour law in Denmark

8.2 The Temporary Agency Work Directive as a concrete example of Directive implementation in Denmark

9. Finnish TSN-YTN Case with Some National, Nordic and European

Reflections

Jari Hellsten .

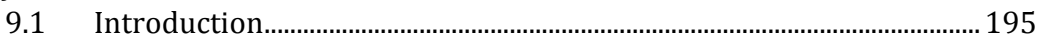

9.2 Essence of the collective agreements and national proceedings ........ 196

9.3 Question about the Parental Leave Directive: the Advocate-

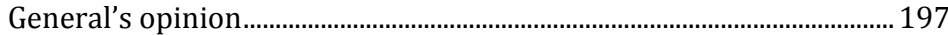

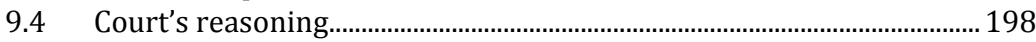

9.5 Some case-related assessment in context.................................................199

9.6 Epilogue in the Finnish Labour Court.........................................................202

9.7 Some national, Nordic and European reflections ....................................203

10. A European Minimum Wage

Jens Kragh

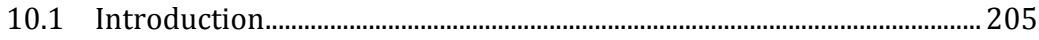

10.2 Does the EU have competences as regards wages? ................................205

10.3 The crisis changed the legal basis ...........................................................206

10.4 The Troika sets a new agenda.....................................................................208

10.5 Softer management through the European Semester.............................209

10.6 Minimum wages in European countries are highly diverse.................. 211

10.7 The ETUC is divided on the need for a European minimum-wage

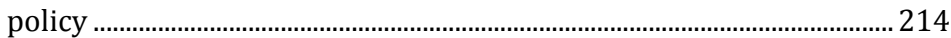

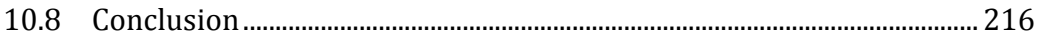

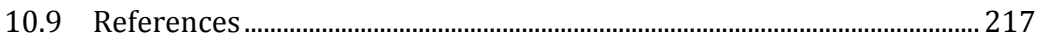


11. The EU's Attempt to Regulate Wages in the Financial Sector Ella Sjödin

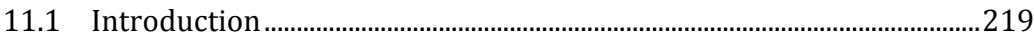

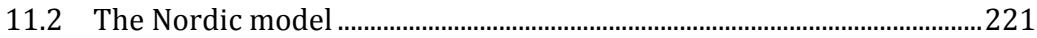

11.3 The financial crisis and the wish to regulate............................................222

11.4 How the EU approaches wage regulation..................................................223

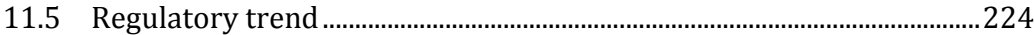

11.6 Guidelines issued by the European supervisory authorities................227

11.7 What can we expect? .............................................................................229

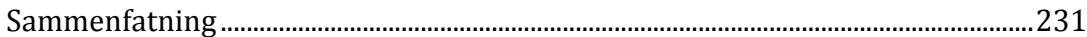




\section{Foreword}

The Nordic model is unique, with its strong independent social partners, high rates of trade-union membership and extensive labour-market regulation through collective agreements. It is above all unique from a broader European and international perspective. It is a flexible model that has developed depending on the preconditions of each Nordic country. In Iceland and Finland, the collective agreements concluded by the social partners have general applicability, in Denmark and Sweden, the labour market is characterised by the freedom and right to conclude collective agreements, while in Norway, a combination of the two systems prevails. The Nordic model is the fundamental basis for achieving the goals on economic, social and ecological development, growth and welfare. The combination of strong welfare systems, flexible collective bargaining models and increasingly green companies and operations promotes growth and reinforces Nordic competiveness.

The backbone of the Nordic model is its system of collective agreements. One of its strengths is how, through the responsibility taken by the social partners, it has developed and changed over time in keeping with the preconditions that have prevailed at any point in time. At the same time, the model and the agreements are facing huge challenges on many fronts. One such challenge is when the Nordic collective agreements and their regulatory framework clash with the generally detailed legislation of the EU. Conflicts often arise as to how the legislation is to be interpreted in a Nordic context. Another difficulty is that the Nordic countries implement EU Directives and legislation differently. The differences in implementation give rise to new border restrictions in the common Nordic labour market.

It is in this light that the Council of Nordic Trade Unions took the initiative to set up this project. The aim of the project is to highlight how the autonomy of the Nordic model is related to the legislative requirements of the EU and to analyse where and why problems emerge during implementation and application. The present anthology achieves this by describing 
different situations and conflicts that have arisen from labour-market regulation in the Nordic countries or that are linked to the Nordic Area.

The project aims to fill a knowledge and information gap regarding the problems that arise from EU legislation, international conventions, national legislation and collective agreements, as well as in relation to the practices that have been developed. The anthology is aimed at employees, employers, the social partners in the Nordic model, legislators at both national and EU level, states, researchers and organisations, as well as anyone wishing to learn more about the Nordic model. The project is cofunded by the Nordic Council of Ministers, which has enabled the publication of this anthology.

In late 2014, the Nordic labour-market ministers decided to commission a strategic review of the common labour market with the aim of intensifying Nordic cooperation. This will include looking into the preconditions for tripartite discussions at Nordic level and enhanced cooperation regarding EU/EEA issues and international matters. We hope that this anthology will contribute to broadening the perspectives and to the work on the strategic review.

Finally, I would like to thank our editor, Professor Jens Kristiansen, University of Copenhagen, for his professional diligence both in creating a sense of coherence in the anthology and in analysing the problems and challenges in a thought-provoking and stimulating manner. I would also like to thank all the co-authors for their involvement and interest. We are very grateful that you wished to share your knowledge and experience of problems and challenges facing the Nordic labour market in relation to EU regulations. Without your contributions and interest, we would not have been able to publish this anthology. Last but not least, I would like to thank our two project coordinators, Maria Karlman Noleryd and Alma Joensen, who have coordinated the work with exemplary dedication and have thus made the realisation of this project possible.

Stockholm, April 2015

\author{
Magnus Gissler \\ General Secretary \\ The Council of Nordic Trade Unions
}




\section{Summary}

This report illustrates a number of the challenges faced by the labour-law systems of the Nordic countries as these interact with the EU, the EEA and the European Human Rights Convention. The report focuses on the general influences of these European systems and the way that these are dealt with in the Nordic countries.

In a general analysis, Professor Jens Kristiansen, Dr. jur., University of Copenhagen, emphasises that European influences vary from one country to the next, but that the challenges faced by the Nordic labour law systems share a number of common features:

The ever-increasing complexity of the European law system: All Nordic labour law systems interact with a European law system which is becoming increasing unmanageable. European law develops in a complicated interaction of different types of sources of law, such as general principles of law (treaties) and specific rules (directives). European rules address conflicting considerations, e.g. promotion of free movement and securing basic trade union rights, and the three European courts do not necessarily take the same approach to these considerations. This complex formation of law often makes it difficult to precisely determine European obligations.

Shifting national balance between legislation and labour market contracts: Legislation has become more prominent in all Nordic countries as part of the implementation of European obligations. However, there has been no basic change in the division of work between the legislature and the social partners, and collective agreements still play an important role in determining wages and working conditions in all Nordic countries. However, the right to freely exchange services seems to present special challenges to the Nordic systems and continues to spur political debate as well as lawsuits on matters of principle.

The ever-increasing importance of the courts in the labour law system: The courts have gained a more prominent role in regard to both the social partners and the legislature. To the widest extent possible, the courts 
must interpret national law in accordance with European obligations, which includes the dynamic development of general, vague principles of law. The courts may also test whether national rules are compatible with European obligations, e.g. whether legislative intervention in a labour market conflict was "necessary". This is bound to continually narrow the political freedom of action and make it more difficult for employers and wage-earners to find common ground based on a specific understanding of national law.

In a number of specific contributions, practitioners from employer and wage-earner organisations address some of the challenges experienced by the social partners in the different Nordic countries as regards the interaction between European systems and national labour-law systems. These contributions focus on topics such as posting of workers, implementation of labour law directives and the increasing European interest in national wage policies. 
Part 1 



\section{European Challenges of the Nordic Collective-Agreement Model}

Jens Kristiansen ${ }^{1}$

\subsection{Introduction}

The purpose of this contribution is to shed light on a number of the general challenges faced by the Nordic labour-law systems in an increasingly well-developed European legal system. This analysis addresses both the European impact and the way in which the Nordic countries have handled the European challenges concerned.

The analysis focuses on the influence of the European Union, EEA cooperation and the European Human Rights Convention under the Council of Europe. These European institutions and conventions are characterised by having efficient judicial control in the form of the European Court of Justice, the EFTA Court and the European Court of Human Rights.

The basis for this analysis is the study of the impact of EU law on the Danish labour-market model: an analysis I published in "The Danish labour-market model and its European challenges" in 2013. To this must be added a number of other - some inter-Nordic - studies of the impact of EU law on the labour-law systems of the Nordic countries: these are stated in the literature list.

\footnotetext{
${ }_{1}^{1}$ Professor, Dr. jur., the Faculty of Law, University of Copenhagen.
} 
The analysis starts by highlighting some general differences and similarities of the labour-law systems in the Nordic countries and their connection with European institutions (section 2). This is followed by an analysis of the challenges imposed by free movement - and, in particular, the free exchange of services - on the labour-law systems in all the Nordic countries (section 3). Further, the analysis deals with the growing role of fundamental rights, including the new practice of the Court of Human Rights concerning the right to collective bargaining and industrial action as part of the freedom of association (section 4). This is followed by a review of the harmonisation of working conditions introduced via labourlaw Directives, the different ways Directives are implemented in the Nordic countries, and the interaction between the national courts and the European Court of Justice in the interpretation and application of the rules (section 5). The EU's harmonisation of working conditions has gradually been supplemented by the coordination of employment policies, expressed for example in the country-specific recommendations to carry out labour-market reforms (section 6). The analysis ends by emphasising some general, transverse development trends as regards European law and the impact on Nordic labour-law systems (section 7).

\subsection{The Nordic collective-agreement model in a European perspective}

\subsubsection{The Nordic labour-market model - similarities and differences}

In labour-law contexts, it is normal to talk about "a Nordic agreementbased model" vis-à-vis "a continental law-based model". The purpose of this distinction is to stress the fact that the Nordic countries share a number of common features compared with other European countries.

Common features of the Nordic countries are a high level of organisation for both wage-earners and employers; the fact that collective agreements play an important role in labour law systems; the fact that collective agreements normally stipulate wages and working conditions sys- 
tematically in the individual industry of trade; and the fact that labour law plays a limited role compared with most other European countries.

The striking feature of the Nordic collective-agreement systems compared with other European countries - is that these agreements bind both the parties themselves and their members. The peace obligation, which is linked to the collective agreements, applies to both the parties to the agreements (the organisations) and the wage-earners who are members of the trade unions concluding the agreements. However, this joint model is not entirely without exceptions, since Finnish wage-earners are not subject to any collective peace obligation.

For all intents and purposes, employers bound by these agreements must comply with the wages and working conditions of the agreements in regard to all wage-earners working in the industrial sector. Conversely, the Nordic countries use different mechanisms to broaden industry agreements to cover employers outside the employer organisations.

In Denmark and Sweden, it is up to the trade unions to conclude agreements ("accession agreements") with employers outside the employer organisations, which involves broad access to using industrial conflict, including sympathy conflicts. In Finland and Iceland, there is a system of generally applicable agreements, so that industry agreements are broadened either automatically or via a public body to apply to all employer and wage-earners in the given industry. Norway is somewhere in between in that trade unions are allowed to use industrial conflict as in Denmark and Sweden, but a mechanism has been introduced to make (selected parts of) collective agreements generally applicable with the aim of ensuring that the terms of foreign wage-earners equal Norwegian wage-earners in an effort to prevent social dumping on the Norwegian labour market.

There is no statutory minimum wage in the Nordic countries for all or parts of the labour market, apart from the wage that comes from generally applicable agreements in Finland, Iceland and Norway. There is a substantial difference in the role played by labour-market legislation in regard to other working conditions. While Denmark and Iceland are still largely characterised by collective agreements, employment legislation plays a bigger role in Sweden and a prominent role in Finland and Norway. There are also clear variations in the level of protection in a number of areas, e.g. 
as regards the right to terminate employees. Employers have freer access to terminating employees in Denmark and Iceland than in, especially, Norway and Sweden, where a terminated wage-earner may also remain on the job if the wage-earner questions the objectivity of the termination before the court.

A common feature of Nordic countries is that the social partners exert considerable influence on the contents of labour-market legislation. There is a long tradition of ensuring that labour-market legislation is designed in a collaborative effort involving the government and the social partners. Inclusion of the social partners materialises in different ways, e.g. in that they participate in expert committees and fact-finding work, or in a direct dialogue with the ministers in charge.

The organisations play a key role in settling industrial disputes in all the Nordic countries. The collective-agreement parties have ownership of the collective agreements and are able to admonish parties in case of a breach of the agreements affecting wage-earners outside the agreements.

Most disputes are settled before the Industrial Court. In Sweden, the Industrial Court has competence within all labour-law legislation, while in the other countries, the competence covers disputes concerning or arising from a collective agreement.

Both the dedicated industrial courts and the ordinary courts of law are characterised by considerable loyalty towards the political and labourmarket compromises expressed through collective agreements and labour-market legislation. The courts attach great importance to the common starting point of the parties to the agreements when it comes to interpreting collective agreements and the legislator's intentions (interpretative notes) in the interpretation of laws. The Nordic court tradition is not just an expression of loyalty to the social partners and the legislature, it also protects the right of the individual - in this case wage-earners and employers - to take an approach which is based on trusting agreed or adopted rules. 


\subsubsection{Council of Europe - the European Human Rights Convention}

The Council of Europe is the broadest European body of cooperation in terms of the number of member states, since 47 countries are now members. European is broadly defined, since the Council of Europe also includes Russia, Turkey and Ukraine as members.

The Council of Europe is a traditional international institution - focused on humanitarian cooperation - where adopted conventions are only binding on the member states which have ratified them. The European Convention of Human Rights of 1950 has been ratified by all member states and has the status of being the most important common European legal basis for the human rights of the people of Europe. The Convention lays down a number of individual rights and political rights, such as the freedoms of speech, assembly and association. It largely does not contain any rights of a social or labour-market nature (financial rights), though such rights have been laid down in the European Social Charter, which has not, however, become as widespread and has not achieved the same status as the Human Rights Convention.

The European Human Rights Convention is special in terms of international law, since individuals may complain to the European Court of Human Rights, claiming breach of the Convention by member states. The claimant must have exhausted all national legal remedies first, i.e. must have brought his or her claim before the national courts. The Court of Human Rights will first decide whether to process a case on its merits, or whether it should be refused as manifestly unfounded. The Court's decision is legally binding and may order a state to pay compensation to the claimant in case of a breach of the Convention.

The provisions of the Human Rights Convention are designed as general principles of law, which are then given more specific contents through the ongoing interpretation of the Convention by the Court of Human Rights. Thus, the wording of the Convention does not specify the special obligations undertaken by the member states. The Court of Human Rights has taken a dynamic approach to interpreting the general principles in light of societal developments ("present day conditions"). One of the prominent - and highly debated - development lines in the case law of the Court of Human Rights is that member states must not only refrain 
from infringing the actual rights of individuals, but must also protect individuals against infringements by other individuals. This may make it necessary for the state to introduce new legislation to meet this requirement in regard to the protection of individual rights.

The Nordic countries were among the first to ratify the convention, although Finland did not ratify it until 1990. On the other hand, Finland was the first Nordic country to integrate (incorporate) the Convention into national law, and the other Nordic countries followed suit in the 1990s. In all five countries, the Convention has been incorporated with the force of regular legislation, but it is likely that the Convention has varying legal status in the different countries.

In Norway, for example, Sect. $110 \mathrm{C}$ of the Constitution specifies that government authorities must respect human rights, but this provision is not directed specifically at the Convention. On the other hand, it follows from Norway's incorporating legislation that the Convention takes precedence over other conflicting legislation. In Sweden, the Form of Government Act (Chapter 2, Sect. 19) specifies that legislation infringing the Convention may not be adopted; this may mean that the courts can (must) disallow legislation infringing the Convention. In Denmark, the Constitution does not mention the Convention, and the interpretative notes for the incorporation Acts show that there was no intention to shift the balance between the courts and the legislature.

\subsubsection{The European Union and EEA cooperation}

The European Community was established in 1957, and Denmark was the first Nordic county to join in 1973. The other Nordic countries joined the EEA cooperation in 1994, and the year after Finland and Sweden joined the European Union. Thus, Denmark, Finland and Sweden are members of the EU today, while EFTA countries Iceland and Norway participate in the Single Market via EEA cooperation.

Denmark, Finland and Sweden are covered by the obligations specified in the EU Treaties - the Treaty on European Union (TEU) and the Treaty on the Functioning of the European Union (TFEU). However, only Finland is fully obliged by the treaties, since Denmark and Sweden have opt-outs, e.g. in regard to the single currency (the euro). 
Iceland and Norway are covered by the Agreement on the European Economic Area (the EEA Agreement). With the EEA Agreement, these two EFTA countries participate in the Internal Market and are also obliged to implement EU rules relating to the Internal Market. Consequently, Iceland and Norway are for all intents and purposes bound by the same EU rules on the labour market as Denmark, Finland and Sweden. However, they are not under an obligation to implement the Employment Directive (2000/78), which prohibits discrimination based on age, disablement, etc. This Directive was not adopted under the Treaty's rules on social policy (TFEU, Article 153), but under a specific Treaty provision on combating discrimination (now TFEU, Article 19), which was introduced with the Amsterdam Treaty after the EEA Agreement had been concluded.

The EU Commission and the European Court of Justice can control and enforce EU legislation (and the EEA Agreement) vis-à-vis the EU Member States, while they do not have competence vis-à-vis EFTA countries. However, by virtue of the EEA Agreement, the EFTA countries are subject to corresponding control and enforcement bodies in the form of the EFTA Surveillance Authority and the EFTA Court. Consequently, there are two parallel enforcement mechanisms, but the EFTA Court must wherever possible interpret the rules in accordance with the case law of the European Court of Justice.

By contrast with the European Human Rights Convention, an individual may not file a case against a Member State before the EU Court of Justice or the EFTA Court. Both the EU Commission and the EFTA Surveillance Authority may, however, admonish Member States in case of alleged Treaty infringement and may take them to the European Court of Justice and the EFTA Court, respectively if they do not rectify their legal situation in line with the criticism voiced. This enforcement mechanism plays an important role when it comes to having Directives (correctly) implemented in the national systems.

An individual may file a case before the national courts and in this way seek to obtain the legal position arising from EU and EEA law. The national courts may bring issues of ambiguities in the EU or EEA framework before the European Court of Justice or the EFTA Court. The direct cooperation of national courts with the two European courts is one of the main reasons for the effective compliance with EU and EEA law, seen in an in- 
ternational perspective. However, there is a formal difference between the two courts, in that the European Court of Justice issues binding, preliminary rulings, while the EFTA Court issues advisory opinions.

To the greatest extent possible, the national courts are obliged to interpret national law in accordance with EU law. If this is not possible, the courts may be bound to give EU law priority (direct effect) over conflicting national law. Directives do not have a direct effect as regards private employers, but may have so in regard to public-sector employers, provided the implementation deadline has been passed and the rule has an adequately precise and unconditional content. If it is not possible to interpret national law in accordance with EU law, or to apply EU law directly, the state may become liable to pay compensation if the national legal position violates EU law; the judgment of 24/1/2012 in C-282/10 (Dominguez) is a case in point.

To the greatest extent possible, the national courts are also under an obligation to apply national law in conformity with the EEA. Conversely, the courts are not bound to use EEA with priority over conflicting national law, but the EFTA countries are obliged to grant implemented EEA rules priority over other national legislation in their national court systems. In cases where an EEA rule has not been (correctly) implemented in national law, individuals may claim compensation from the state if they have suffered a financial loss due to the legal position at variance with EEA law; a case in point could be the judgment of 3/10/2007 in E-1/07.

\subsection{Free movement within the Internal Market}

\subsubsection{Free movement and low-wage competition}

The realisation of an Internal Market for wage-earners and enterprises is one of the important objectives of the European Union. With the EEA Agreement, this objective has been widened to include Iceland, Liechtenstein and Norway.

The EU rules on free movement do not aim to harmonise the legal systems, including the labour market systems, of the Member States. The primary purpose of the rules is to give wage-earners and employers free 
access to the (labour) market(s) of all Member States. The significance of free movement has grown steadily with the enlargement of the EU, particularly with the striking enlargement in 2004. These most recent enlargements have thus led to marked variations in living and working conditions. The Nordic countries are among the "high-wage countries" with a wage and cost level at the high end of the scale.

The relocation of workplaces by Nordic companies to other parts of the EU (and the world) has not given rise to any significant trade-union or political struggles. Nordic trade unions generally accept that companies relocate activities to other countries. The primary disagreements arising from such relocation have concerned situations in which - after relocation - companies carry on their activities in a Nordic country, but now using a foreign collective agreement. This was the issue which resulted in the European Court of Justice judgment of 11/12/2007 in C-438/05 (Viking) in a conflict between a Finnish trade union and a Finnish shipowner, which wanted to reflag a ship with the primary purpose of replacing a Finnish collective agreement with an Estonian agreement on a route between Finland and Estonia.

The use of foreign labour by Nordic companies has been more controversial than the relocation of (parts of) the company to "low-wage countries". This applies in particular to posted workers who are not comprised by the principle of equal treatment which applies according to the EU rules on the free movement of workers.

The concept of workers is not defined in Article 45 of TFEU or in the supplementary Regulation on the free movement of workers but, according to the preamble, the Regulation was also aimed at posted wageearners. However, the European Court of Justice - unlike the EU Commission and the Advocate-General - displayed a different understanding of the concept of workers in its judgment of 27/3/1990 in C-113/89 (Rush Portuguesa). According to the Court, posted workers are not covered by the wage-earner concept, but are part of the service provided by the undertaking. According to the judgment, however, the host country was entitled to instruct foreign service provides to comply with labour laws and collective agreements in regard to the posted employees.

The judgment showed that there was no unequivocal view of the conditions which apply to posted wage-earners. This ambiguity was rein- 
forced by the point of departure of the Rome Convention from 1980 which stated that, when working temporarily in another country, wage-earners would comply with the rules of the home country (Article 6(2)), although internationally prescriptive protection rules had to be met (Article 7). Correspondingly, the Regulation on the coordination of social security payments specified that posted wage-earners were comprised by the social security rules of their home country (then Article 14 of Regulation 1971/1408).

In 1991, the Commission put forward a draft Directive on the posting of workers as part of the exchange of services with the primary purpose of providing more clarity about the conditions which were to apply when employees were posted across EU national borders (COM (91) 230). In its introductory comments to the draft (p. 4), the Commission described the general challenge as follows:

\footnotetext{
"The question is therefore one of finding a balance between two principles which find themselves in contradiction. On the one hand, free competition between firms, including at the level of subcontracting across borders, so that the full benefits of the Internal Market can be realised, including by firms based in Member States whose main competitive advantage is a lower wage cost. On the other, Member States may decide to set and apply minimum pay levels applicable on their territory in order to ensure a minimum standard of living appropriate to the country concerned."
}

Following a long, complicated political process, the Posting of Workers Directive was adopted in 1996 (Directive 1996/71). The adopted Directive maintains the central provision in the Commission's draft, according to which Member States must ensure that posted workers are also covered by the rules of legislation and generally applicable collective agreements on a number of specified working conditions. Among the conditions listed was a "minimum wage", which was to be laid down in accordance with "national legislation and/or practice" (Article 3(1)). Furthermore the political process had resulted in a number of difficult-tograsp rules in Article 3(2)-(10). While one of the provisions made it possible to give posted workers better protection (Article 3(7)), another provision assumed that this could only be done in accordance with basic legal principles (Article 3(10). In addition, a provision was inserted which made it possible for the host country to rely on wage and working condi- 
tions in collective agreements which were not generally applicable in the normal sense (Article 3(8)).

The fact that the Posting of Workers Directive is both complicated and controversial became abundantly clear with the European Court of Justice judgments of 18/12/2007 in, C-341/05 (Laval), 3/4/2008 in C-346/06 (Rüffert) and 19/6/2008 in C-319/06 (the Commission v. Luxembourg). These judgments led to critical reactions, e.g. from the ETUC, which wanted a protocol to the Lisbon Treaty to specify that trade-union rights took precedence over free movement. No protocol to the Lisbon Treaty was prepared, but the European Council confirmed in a statement from the December 2008 summit that the EU attaches great importance to "social progress and workers' rights."

In the spring of 2012, the Commission presented a proposal for a Regulation on the exercise of industrial-conflict rights within the framework of free movement and a Directive on enforcement of the Posting of Workers Directive. The draft Regulation was presented with the "flexibility clause" in TFEU Article 352 as its legal basis. The Nordic countries used the new procedure of the Lisbon Treaty to give this proposal a "yellow card" for infringing the principle of subsidiarity (protocol 2 on the use of the principles of subsidiarity and proportionality). The Commission could have tried to give more detailed reasons for its proposal, but chose to withdraw it.

With its proposal for a separate Enforcement Directive, the Commission avoided opening up the politically sensitive debate about Article 3 in the Posting of Workers Directive. Slightly simplified, the Commission's proposal involves all the elements of the Posting of Workers Directive except the group of wage and working conditions which a host country may impose on foreign service providers (Article 3). The proposal was adopted in the spring; it includes in Article 12 a rule concerning the liability of a contractor for the wage and working conditions of a subcontractor (Directive 2014/67).

The new Commission has a "targeted review" of the Posting of Workers Directive on its work programme for 2015 in an overall package intended to strengthen the mobility of the labour force and counteract abuse of the rules. Until now however, Article 3 of the Directive and the case law of the European Court of Justice and the EEA Court are the pivot- 
al points when it comes to the requirements which the host country may impose on foreign service providers.

In the following, some of the challenges facing the Nordic countries in handling the minimum wage issue are addressed. It is striking that the countries have used rather different implementation models and that they have all been the subject of principal cases before the European Court of Justice and the EFTA Court.

\title{
1.3.2 Prevention of social dumping in the Nordic countries
}

\section{The right to industrial action as a pivotal force in Denmark and Sweden}

When implementing the Posting of Workers Directive, both Denmark and Sweden refrained from instructing foreign service providers to maintain a certain minimum wage. It was broadly agreed that it should be left up to the social partners to ensure that posted workers work under decent wage and working conditions. The largely identical implementation of the Directive in the two countries suffered a serious blow through the European Court of Justice judgment of 18/12/2007 in C-341/05 (Laval). Both countries chose to maintain the original starting point in a new statutory framework, but with the social partners in a somewhat different role.

\begin{abstract}
a) Sweden
The background for the Laval judgment was industrial action taken by Swedish trade unions (Svenska Byggnadsarbetareförbundet, Byggettan and Svenska Elektrikerförbundet) against a Latvian construction company (Laval un Partneri), which had posted a number of construction workers to its Swedish subsidiary as part of a construction project. The trade unions wanted Laval to accede to the normal construction agreement on the Swedish labour market and guarantee the posted workers an hourly wage of minimum SEK 145. Laval concluded an agreement with a trade union in Latvia and took the question of the legality of the industrial action to the Industrial Court in Sweden. The Industrial Court asked the European Court of Justice whether it was compatible with EU law, firstly, to take collective industrial action in support of an agreement with a foreign ser-
\end{abstract}


vice provider and, secondly, to allow Swedish legislation to give foreign service providers with a collective agreement in their home country poorer protection against industrial action than a domestic service provider with a Swedish collective agreement.

The European Court of Justice recognised that the right to take industrial action has the status of a fundamental right, also by virtue of Article 28 of the EU Charter, but could not apply such a right outside the area covered by the rules on free movement. The ban of the Treaty against restrictions to the free exchange of services also applied to trade unions, since - like the state - they have authority to regulate the exchange of services collectively. Even if a blockade could constitute a legitimate restriction of the free exchange of services, there were no compelling reasons in the specific case. The Court found it important that Laval was obliged to comply with the minimum protection in Sweden which was within the scope of Article 3(1) of the Directive and which at the same time constituted the level which the host country may instruct the foreign service provider to observe. A requirement concerning (local) wage negotiations could not be justified with compelling reasons either, since this would mean that the company could not know in advance which obligations it would have to meet as regards minimum wages. Summing up, the Court stated that the rule of the Treaty concerning free exchange of services and Article 3 of the Posting of Workers Directive meant that the industrial action taken by the Swedish trade unions was unwarranted. Furthermore, the ban of the Treaty on discrimination was also infringed in that the Swedish co-determination legislation did not offer Laval, with its Latvian agreement, the same protection as a Swedish company with a Swedish agreement.

With this judgment, the Court thus found the "hardcore" wage and working conditions in Article 3(1) to be the decisive political compromise. Any improvement of the level of protection may not be based on Article 3(7) - which assumes voluntary accession by the service provider - but must comply with the requirements in Article 3(10) on fundamental principles of law. The Court thus chose its standard approach, which is to interpret unclear Directive rules in favour of free movement.

The Posting of Workers Directive was of no direct significance for this issue, since it is aimed at the Member States. However, the European 
Court of Justice interpreted the Treaty-enshrined right to free exchange of services (now TFEU, Articles 56 and 57) to mean that it not only bans restrictions by states, but also restrictions by trade unions. This meant that the decisive point was whether the industrial action concerned compiled with the normal requirements concerning restrictions in the free exchange of services, which the Court found not to be the case.

The Swedish Industrial Court subsequently issued a judgment against the Swedish trade unions, ordering them to pay Laval compensation for having initiated illegal industrial action. In its judgment of 2/12/2009 (AD 2009/89), the Industrial Court disregarded the fact that the trade unions had taken industrial action in accordance with an unambiguous Swedish legal position. Swedish legal position had to give way to the Treaty-based ban on unjustified restrictions on free exchange of services; according to the EU judgment, this had a direct impact on the Swedish trade unions. The Industrial Court also found that private associations are liable to pay compensation in accordance with the same principles as Member States when they become liable for a legal position which violates an EU rule. Furthermore, the Industrial Court found that this was a case of infringement of an unambiguous rule of EU law, but the Court did not find that Laval had documented an alleged financial loss, so the trade unions were only ordered to pay a loss-independent compensation of SEK 550,000.

The EU judgment also led to a - controversial - amendment of the Swedish Posting of Workers Act on the basis of prior committee work (SOU 2008:123 on proposed measures resulting from the Laval judgment). Even if the report was submitted in December 2008, an amendment to the Act was not adopted until April 2010. The proposal put forward by the government gave rise to considerable political debate, and the question of compatibility with freedom of association in the Form of Government was asked. With the adopted amendment of the Posting of Workers Act, the access of Swedish trade unions to take industrial action towards foreign service providers was restricted to the question of minimum wage in accordance with nationwide collective agreements (Article 3(8), 2nd paragraph, 1st sentence). At the same time, the right to take industrial action was only granted if the foreign service provider cannot substantiate that it already complies with the minimum wage in accordance with the relevant nationwide collective agreement. 
The fact that the Swedish Laval solution is controversial can also be seen from the complaint filed by the big Swedish trade union organisations, $\mathrm{LO}$ and TCO, with the ILO about the restrictions imposed in regard to the right to take industrial action. In the spring of 2013, the ILO Committee of Experts criticised the amendment (Report of the Committee of Experts on the Application of Conventions and Recommendations, International Labour Conference, 102nd Session, 2013, p. 176ff). Following a complaint from the same associations, the Council of Europe's Social Rights Committee has also criticised the restriction of the right to take industrial action, citing that it is irreconcilable with the right to take industrial action without discrimination in Articles 6 and 19 of the European Social Charter (decision of 3/7/2013 in complaint case 85/2012). The criticism from the Council of Europe is particularly conspicuous, since the European Social Charter forms part of the fundamental values of the EU, since there is a reference to the Charter in the preamble to TEU and Article 151 of TFEU.

\section{b) Denmark}

The Laval judgment not only questioned Swedish industrial action practices, but also Denmark's- almost corresponding - practices. Unlike Sweden, the Danish social partners gave priority to finding a common solution to the challenge brought about by the Laval judgment.

The Minister for Employment established a working group under the auspices of the Implementation Committee with the participation of the social partners, with the purpose of designing a proposal which would both comply with the judgment and maintain Danish industrial action rules. A broad political majority stated in a European policy agreement already in February 2008 that they focused on "maintaining the right to take collective industrial action, since this right forms an important part of the Danish labour market model".

The Laval committee presented its report in June 2008 (report of 19th June 2008 from fact-finding work relating to the Laval decision). The committee proposed unanimously that a new rule on the right to take industrial action be entered into the Posting of Workers Act; this proposal was adopted, unamended, by a broad political majority of political parties in December 2008. The new provision is different from the Swedish provision because it links the minimum wage to collective agreements conclud- 
ed by the most representative parties on the Danish labour market (Article 3(8), 2nd paragraph, 2nd sentence). The biggest difference, however, lies in the fact that this rule - unlike the Swedish rule - does not eliminate the right to take industrial action even if the foreign service provider already pays wages that are in accordance with the minimum wage laid down in a collective agreement.

The willingness of the social partners to compromise was not - as had otherwise been assumed in the interpretative notes to the Act - great enough for them to design joint "Laval agreements" which would specify the minimum wage. The trade unions therefore designed their own paradigms for collective agreements for foreign service providers, focusing on calculating the minimum wage as clearly as possible. In a judgment of 20/2/2014 (2013.0828), the Industrial Court deemed industrial action towards a German service provider in support of accession to an "accession agreement for posted companies" to be within the realm of the law. The Industrial Court found that the wage rates corresponded to the rates in the industry agreement and that this agreement was freely accessible via the website of both the Danish Master Painters' Association and the Painters' Trade Union. The minimum wage included a number of converted social payments (such as holiday leave and pensions), although the company was able to set off any payments of corresponding social contributions for corresponding schemes in Germany.

DA, the Confederation of Danish Employers, and LO, the Confederation of Danish Trade Unions, agreed to avoid taking industrial action against foreign service providers to the greatest extent possible. When the collective agreements were renewed in 2010, arrangements were introduced in all areas covered by DA and LO obliging, to a varying extent, companies bound by the agreements to help clarify the wages and working conditions of subcontractors and to try to find an acceptable solution for all parties involved. In many cases, the negotiation procedure laid down has meant that foreign service providers have concluded an agreement with the Danish trade union. A number of industrial disputes are in progress, dealing with the compatibility of the concluded agreements with the Posting of Workers Directive and with the Treaty-based right to free exchange of services, cf. also the umpire verdict of $31 / 10 / 2014$ in the industrial arbitration case 2014.90 between the trade union 3F and Solesi, in which 
the umpire chose to refer to the Industrial Court the question of possible prejudicial submission to the European Court of Justice.

\section{Generally applicable collective agreements in Finland and Iceland}

\section{a) Finland}

As opposed to Denmark and Sweden, Finland has an arrangement which makes it possible to broaden the field of application of collective agreements to non-organised employers. According to the Work Agreement Act, all employers within a given industry must thus respect the wages and working conditions laid down in a nationwide agreement which is representative of the industry. It is up to a public committee to make an overall assessment of whether the agreement is representative of the industry. The Finnish Posting of Workers Act orders foreign service providers to accept the minimum wages laid down in the generally applicable agreements. The setting of the minimum wage thus depends on the specific, generally applicable agreement.

The Finnish model differs from the Danish and Swedish models in that the government - via a generally applicable agreement - orders foreign service providers to observe a specific minimum wage. Two claims against generally applicable Finnish agreements - with a relatively broad determination of minimum wage - have been filed with the Finnish courts by a Polish company. In the case, a Finnish trade union (Sähköalojen ammattiliitto) advanced a wage claim on behalf of 186 posted Polish workers against a Polish company (Elektrobudowa) based on two generally applicable agreements. The trade union found, among other things, that the employees should have been offered work on piece-rate terms and be placed in different wage brackets, and also that they were entitled to holiday pay, a fixed per diem and transport time compensation. The company found that these requirements infringed the Posting of Workers Directive and the rule of the Treaty on free exchange of services. The Finnish court submitted a number of questions to the European Court of Justice to clarify whether various collective-agreement terms were comprised by the minimum wage concept of EU law.

The Advocate-General questioned whether the Finnish system was compatible with EU law, since in some cases companies with a Finnish agreement are able to deviate from the generally applicable agreement. 
Since the court submitting the question to the European Court of Justice had not asked this question, however, the Advocate-General did not address the question specifically. Furthermore, it was the AdvocateGeneral's view - partially with reference to the Laval judgment - that in agreements with both hourly pay and piece-rate pay, the minimum wage would have to be the lower of the two wage rates (the hourly pay), that extra holidays (holiday allowance) may form part of a minimum wage, but not in relation to the normal wage, and that per diem and transport compensation are often not required for the social protection of the posted workers. For the last of these points, the Advocate-General did not rely on Article 3 of the Directive, but on the general rules on free exchange of services in Articles 56 and 57 of TFEU.

In its judgment of 12/2/2015 in C-396/13 ((Elektrobudowa), the European Court of Justice found that the host country's rules on minimum wages must be "binding" and "transparent" in order to be invoked against a foreign service provider. The Court left it up to the submitting Finnish court to assess whether these two requirements had been met; in practice, this question is primarily a matter about the access which the Work Agreement Act gives to replace a generally applicable agreement with (another) Finnish agreement. Furthermore, the Court found that the minimum wage may be based both on an hourly rate and a piece rate in an agreement, depending on the specific circumstances; that wage-earners may be placed in different wage brackets; and that holiday pay, per diem and transport compensation may form part of the minimum wage. With this judgment, the European Court of Justice emphasised that it is up to the host country to lay down the specific contents of the minimum wage in accordance with the wording of Article 3 (1), last paragraph, of the Directive. Unlike the Advocate-General, the Court did not assess whether the individual wage elements were also in accordance with the general principles of the free exchange of services in Articles 56 and 57 of TFEU. However, on the other hand, the Court did not explicitly rule out the possibility that the wage element may constitute an unjustified restriction in light of the Treaty-based right to the free exchange of services. 


\section{b) Iceland}

Like Finland, Iceland has a general arrangement with generally applicable collective agreements. Employers outside the agreement in a given industry must comply with the wage and working conditions of nationwide agreements. Iceland has also ordered foreign service providers to comply with minimum wages in generally applicable agreements.

On the basis of committee work with the participation of the social partners, 2007 saw a number of amendments to the Posting of Workers Act. Firstly foreign service providers were ordered to report various items of information to the Labour Directorate (Vinnumálastofnun), but the new Act also ordered foreign service providers to pay posted employees normal wages when they were absent due to illness and occupational accidents, and to take out various types of insurance covering the posted employees.

The new Act gave rise to criticism from the EFTA Surveillance Authority, one point being that the obligation to report was too extensive and had the nature of a system of prior approval for the provision of services in Iceland. The EFTA Surveillance Authority was also critical of the rule of the Act which specified full pay during illness and occupational accidents and the obligation to take out insurance, such as accident insurance. This criticism led to an amendment of the reporting obligation rule in the Act, but not to a change to the right to full pay in case of absence due to illness or an occupational accident.

A judgment of 28/6/2011 in E-12/10 went against the Icelandic state, quoting a breach of the EEA Agreement. According to the EFTA Court, full pay during illness and accident could not be deemed to form an element of minimum wages in the sense of the Posting of Workers Directive. According to the Court, the Directive assumes that the wages in case of illness and accident will reflect the minimum wage, not the usual (full) pay. Furthermore, the Court found that the provisions of the Act on compulsory accident insurance concerned working conditions which were outside the hard core of working conditions in Article 3(1). Iceland had not demonstrated that the additional rules were justified by fundamental principles of law in accordance with Article 3(10).

This judgment led to an amendment of the Posting of Workers Act. The provision on compulsory accident insurance was cancelled and it was 
specified that, in the case of absence due to illness or occupational accident, the labour market wage (instead of a full wage) is to be paid.

The new judgment from the European Court of Justice on 12/2/2015 in C-396/13 (Elektrobudowa) is not likely to change the assessment made by the EFTA Court in its judgment. Unlike the Finnish agreements, the Icelandic Act concerning working conditions was outside the hard core of wage and working conditions in Article 3(1) of the Posting of Workers Directive.

\section{Specific, generally applicable collective agreements in Norway}

Norway is in the middle ground between Denmark and Sweden on the one hand and Finland and Iceland on the other. Norway does not have a general arrangement with generally applicable collective agreements, but in 1993 Norway introduced an arrangement with the limited aim of ensuring that foreign wage-earners had equal wage and working conditions and of preventing social dumping from foreign labour.

According to the Act, a public board ("Tariffnemda") may decide that a nationwide collective agreement applies, in full or in part, to all wageearners performing work of the type concerned in an industry or part of an industry. The generally applicable wage and working conditions become mandatory minimum conditions for employment. The Act also allows trade unions extended access to use blockades ("boikott") against foreign service providers in keeping with the rules of the Boycott Act in relation to domestic employers.

According to the Working Environment Act, which implements the Posting of Workers Directive, a foreign service provider must comply with the wage and working conditions of the collective agreements which have become generally applicable pursuant to the 1993 Act. The social partners have not agreed on the need to make agreements generally applicable, and the first time the Act was used was in 2004. Today, generally applicable agreements exist in the construction industry, the shipbuilding and workshop industry including the oil industry, and in agriculture, horticulture and the cleaning services sector.

The arrangement of making selected parts of agreements generally applicable in specially exposed industries has been the subject of a principal court case, which ended before both the EFTA Court and the Norwegian Supreme Court. An employers' association (NI skipsverft) questioned the generalisation of the collective agreement, which ordered all employ- 
ers in the industry to respect the collective agreement rules on the minimum wage, a work week of 37.5 hours, overtime rates of $50 \%$ and $100 \%$, an out-of-town supplement of $20 \%$, as well as covering the costs of travel, board and lodging. The provisions that had been made generally applicable also covered foreign service providers who posted employees in Norway, but the employers' association felt that this violated EEA law, including the Posting of Workers Directive and Article 36 of the EEA Agreement, which corresponds to Articles 56 and 57 of TFEU on the free exchange of services. The Employers' Federation (NHO) and the Confederation of Norwegian Industries entered the case in support of NI skipsverft, while the Norwegian LO and the trade union Fellesforbundet entered the case in support of the government.

The City Court of Oslo found in favour of the state, while the Borgarting High Court chose to submit a preliminary request to the EFTA Court, which gave its opinion in a judgment of 23/1/2012 in E-2/11 (STX). The parties agreed that the out-of-town supplement which had been made generally applicable was in compliance with the conditions regarding "minimum wage" in the Posting of Workers Directive, but disagreed as to whether this was also compatible with Article 36 of the EEA Agreement. The EFTA Court found that the supplement would also have to be assessed on the basis of Article 36 of the EEA Agreement and asked indirect questions as to whether compliance with requirements was ensured, but left the question to the submitting court. A similar reasoning was used in regard to the provision on covering the costs of travel, board and lodging. The High Court used the opinion as a basis, but following a concrete assessment, the High Court agreed with the state that this provision did not violate EEA law.

In its judgment of $5 / 3 / 2013$, the Supreme Court questioned whether the elements formed a minimum wage in the sense of the Directive should also be tested in light of Article 36 of the EEA Agreement. The Supreme Court found it difficult to reconcile the view of the EFTA Court with the case law of the European Court of Justice and stressed that, if these were the same, nothing has been achieved with the Directive, since the aim of the Directive is to coordinate mandatory rules on minimum wages. The Supreme Court did not address this question, since the Court found that the out-of-town supplement was in any event compatible with Article 36, 
as it gives posted wage-earners an objective advantage. Furthermore, the Supreme Court found that a number of weighty reasons exist for demanding that the employer pays for the wage-earners cost of travel, board and lodging. If the wage-earner were to pay these costs himself or herself, this would in reality led to a markedly lower minimum wage. Consequently, in any event, these costs would reflect the fundamental principles of law in accordance with Article 3(10) of the Directive. The Supreme Court also attached importance to the fact that the Norwegian wage-bargaining model has long traditions and forms part of the fabric of the Norwegian society. Since the other conditions that had been made generally applicable were also in line with the Posting of Workers Directive, the Court found in favour of the state.

The Supreme Court judgment is controversial, since - unlike the High Court judgment - it counters the EFTA Court's interpretation of the Posting of Workers Directive. The Supreme Court thus chose - as opposed to the EFTA Court judgment - to question whether the out-of-town supplement and cost cover could be the subject of censorship under Article 36 of the EEA Agreement. This judgment has brought the Supreme Court into open battle with the EFTA Court, whose President, Carl Baudenbacher, strongly criticised the Supreme Court (published in the legal journal Lov og Rett no. 8/2013). NHO has filed a complaint against the judgment with the EFTA Surveillance Authority, which has chosen to review the case to see whether the complaint gives a basis to file a formal case against the Norwegian state. However, the Supreme Court would seem to be in line with the European Court of Justice, which in a judgment of 12/2/2015 in C-396/13 (Elektrobudowa) addressed the generalised Finnish agreements exclusively in accordance with Article 3(1) of the Directive, not supplementing this with Articles 56 and 57 of TFEU. 


\subsection{Fundamental rights in working life}

One of the characteristic features of European law is that it focuses on establishing a number of fundamental rights for individuals. These fundamental rights are predominantly in the form of general principles of law, leaving the detailed interpretation to the European courts. The increasing importance given to fundamental rights presents the Nordic countries with considerable challenges, since they do not have the same constitutional tradition as many other European countries for leaving such far-reaching authority to the courts as a result of vaguely formulated general principles of law.

\subsubsection{Charter of Fundamental Rights of the European Union}

For a long time, although the Treaties of the EU did not contain a catalogue of fundamental rights, the European Court of Justice itself developed a number of general EU principles for the Union to respect, such as the principle of equal treatment. However, with the Nice Treaty, the heads of state and government adopted a political statement concerning a charter on fundamental human rights; through the Lisbon Treaty, this Charter now has the "same legal value as the Treaties" (Article 6(1) of TEU).

The Charter specifies freedom of assembly and of association (Article 12) and prohibits discrimination (Article 21). However, in Chapter IV on "solidarity", the Charter also defines a number of fundamental rights in working life: the right to information and consultation at company level (Article 27); the right to collective bargaining and collective action (Article 28); the right of access to a free placement service (Article 29); protection in the event of unjustified dismissal (Article 30); fair and just working conditions (Article 31); prohibition of child labour and protection of young people at work (Article 32); the right to reconcile family and professional life (Article 33); and the right to social security and social assistance (Article 34).

According to Article 6 of TEU, the Union "recognises" the rights, freedoms and principles laid down in the Charter. This provision does not give the Union separate authority to shape these rights into subsequent political 
agreements. For example, the EU still does not have authority over the right to collective bargaining and industrial action (Article 153(5) of TFEU).

The Charter instructs the EU institutions to observe these fundamental rights when they exercise their authority in different fields. The Council and the Parliament must observe the rights in the Charter in connection with the adoption of labour law directives. If they disregard the Charter, this may invalidate a Directive fully or in part, cf. for example the judgment of 1/3/2011 in C-236/09 (Test-Achats), where the European Court of Justice disallowed a provision in a Directive on equal treatment of men and women in the provision of goods and services, since the provision concerned was not compatible with Article 21 of the Charter, which prohibits discrimination, and Article 23, which lays down equal treatment of men and women. The European Court of Justice itself must also respect the Charter, when it interprets EU rules, cf. for example the judgments of 11/12/2007 in C-438/05 (Viking) and 18/12/2007 in C-341/05 (Laval) on the right to take industrial action. In these two judgments, however, the provision in Article 28 of the Charter was not given decisive influence since, according to this provision, industrial action must be taken in accordance with EU law and national law.

As a derivative function of the Union's obligation to observe the Charter, the Member States must also observe the Charter "only when they are implementing Union law", cf. Article 51(1) of the Charter. It is unclear what is meant by "implementing Union law", but according to the explanatory comments to the Charter, this refers to the case law of the European Court of Justice according to which the fundamental rights "only rest upon the Member States when they act within the framework of EU law". It is thus a precondition if an individual wishes to invoke the Charter against a Member State that the case concerns EU law, cf. for example, the judgment of 5/2/2015 in C-117/14 (Poclava). In this case, the European Court of Justice said it was not competent to assess whether free access to terminating employees during a trial period of one year in a Spanish Act on support to entrepreneurs was compatible with Article 30 of the Charter on unjustified dismissal.

It has not been clarified whether the Charter can also impose obligations on private individuals. In practice, for example, the question is whether the Charter can indirectly give precedence to a Directive over 
conflicting national legislation in disputes with private employers. In its judgment of 15/1/2014 in C-176/12 (Médiation Sociale), the European Court of Justice seems to assume that Article 21 of the Charter on equal treatment may have direct effect in relation to private employers, while this is not the case with Article 27 of the Charter on information and consultation, which - by nature of its contents - assumes implementation via EU law and national law. On the same lines, the European Court of Justice assumes that the general, unwritten EU principle of equal treatment, as codified in Article 21 of the Charter, obliges private employers with an effect that precedes conflicting national legislation, cf. the judgment of $22 / 11 / 2005$ in C-144/04 (Mangold), and the judgment of 19/1/2010 in C-555/07 (Kücükdeveci).

The Charter does not form part of the EEA Agreement, but has an indirect impact on Iceland and Norway, since the European Court of Justice attaches importance to the Charter when interpreting labour-law directives, and since the EFTA Court itself has developed a number of fundamental rights pursuant to the EEA Agreement. In practice, the rights established in the Charter will thus also bind Iceland and Norway, when those two countries implement EEA law. In its judgment of 18/7/2013 in C-426/11 (Alemo-Herron), the European Court of Justice determined that Article 3 of the Transfer of Undertakings Directive on the obligation for the transferee to continue the wages and working conditions of the transferor, which must be interpreted in the light of Article 16 of the Charter on the right to establish and conduct a business. This meant that the UK could not oblige a transferee to respect collective agreements concluded after the take-over, since improved protection of wage-earners may not constitute an intervention in the very substance of the transferee's right to establish and run a business. In its judgment of 18/12/2014 in E-10/14 (Deveci), the EFTA Court failed to directly address the question of Article 16 of the Charter in a case on the interpretation of the Transfer of Undertakings Directive, but noted that the right to establish and conduct a business as self-employed is also recognised in EEA law. The judgment does not state whether the right to run a business played an independent role in the interpretation of Article 3 of the Transfer of Undertakings Directive in the case concerned. 


\subsubsection{European Convention on Human Rights}

Whereas the EU Charter of Fundamental Rights is directed primarily at the Union's own institutions, the European Convention on Human Rights is directed at the Council of Europe member states. The Convention thus obliges the member states not to act in violation of the rights laid down in it (Article 1).

The Convention contains several provisions which may be significant to the labour-law systems of the Nordic countries. This applies in particular to Article 6 on the right to a fair trial; Article 8 on respect for private and family life; Article 10 on the freedom of expression; and Article 11 on the freedom of association. The provision with the biggest principal and practical significance for the Nordic labour law systems is undoubtedly Article 11 on the freedom of association.

According to Article 11(1), all persons are entitled to establish and join associations, including trade unions, with the aim of defending their interests. This provision offers wage-earners and trade unions wide protection against hostile behaviour against their organisations from the state or employers, cf. for example the judgment of 2/7/2002 (The National Union of Journalists). However, the European Court of Human Rights has also stated that this provision also includes the right not to join a trade union, as well as the right to collective bargaining and the right to take industrial action. For the member states, this means that interventions against these rights may only be performed if this is "necessary in a democratic society", cf. Article 11(2).

\section{Prohibition against mandatory membership of an organisation}

When the Convention was adopted, a controversial question was whether its purpose was to protect both the right to establish and join an association (positive freedom association) and the right not to join an association (negative freedom of association). Following pressure, also from the Nordic countries, this provision focused only on positive freedom of association, and the interpretative notes stated clearly that this was no obstacle to closed shop arrangements.

Despite the clear wording and the explicit interpretative notes, the European Court of Human Rights in its judgment of 13/8/1981 (British Rail) decided against the UK, since it had not protected three employees against 
dismissal because they refused to join a trade union which had concluded an agreement with their employer. With this judgment, the Nordic countries also faced a potential challenge in the form of negative freedom of association, which was not a concept recognised in national law.

In a judgment of 30/6/1993 (Sigurjonsson), the Court held against Iceland, since Iceland had cancelled a taxicab owner's licence, because he left the association of which he had to be a member in order to get his licence, according to the law. The Icelandic Supreme Court had deemed the obligation to be a member of this association to be compatible with both the Icelandic Constitution and the European Convention on Human Rights. The judgment gave rise to much debate; however, Icelandic law was amended to match the judgment.

In a judgment from 11/1/2006 (Sørensen and Rasmussen), the Court held against Denmark for not granting two wage-earners necessary legal protection against mandatory membership of an organisation. Unlike the Icelandic case, the Danish breach of the Convention did not consist of membership of an organisation ordered by the state, but in Denmark having permitted overly extensive mandatory membership of organisations in connection with collective agreements. While a proposal to prohibit closed shop arrangements had just been rejected following a hectic political debate, the new judgment quickly led to an amendment of the Freedom of Association Act in the spring of 2006 without much political struggle. With the new Act, closed shop arrangement and preferential arrangements became invalid, and employers were ordered not to attach any weight to membership of a given organisation when engaging and dismissing employees. It was broadly agreed among politicians that the Act would not prevent employers from treating member and non-member wage-earners differently during their employment.

It is unclear whether the negative freedom of association in Article 11 of the Convention also means that employees who are not members of a trade union have the right to be treated equally with employees who are. In a judgment of 13/2/2007 (Ewaldsson), the Court failed consider this question in a case where a number of non-union wage-earners automatically had SEK 300 deducted from their wages to cover a wage check carried out by a Swedish trade union in accordance with a collective agreement in the construction industry. Even if the parties focused exclusively 
on Article 11 of the Convention, the Court did not mention this provision, but held against Sweden, stating that Sweden was in breach of Article 1 on property rights in addendum protocol 1 by allowing this automatic wage deduction without any consent from the individual wage-earner. The Swedish judge dissented, quoting that the majority did not find that the time had come to (possibly) take another step towards protecting negative freedom of association. There is an ongoing case before the Danish Supreme Court on whether a sick-pay arrangement specified in a collective agreement which only applies to union member wage-earners is compatible with negative freedom of association.

The question of mandatory membership of organisations has also given rise to cases involving industrial action against (non-organised) employers. In a judgment of 25/4/1996 (Gustafsson), however, the Court of Human Rights ruled in favour of the Swedish state, stating that it had not violated the negative freedom of association of a non-organised employer in that the Industrial Court had declared the action to be lawful in accordance with Swedish law. The Court deemed it important that this was a case of indirect mandatory organisational membership of limited intensity, since the employer could have chosen to enter into an accession agreement instead of joining the employer organisation. Furthermore, the Court emphasised that the right to take industrial action is recognised as a fundamental right and that the Swedish state should be granted a wide margin of judgment when balancing conflicting interests.

With this judgment, the Court actually accepted the Nordic tradition of giving trade unions wide-ranging access to take industrial action against individual employers as an element in broadening collective agreements. On the same lines, the Court rejected a complaint from a Danish company in its decision of $7 / 10 / 2005$; the company had been exposed to industrial action from an LO trade union, even if the company was already covered by an agreement via the Christian Employers' Association. The Industrial Court deemed the action to be lawful, since the two trade unions competed freely against each other; the Court thus refused the complaint as manifestly unfounded. 


\section{Government intervention into industrial action}

Article 11 of the European Convention on Human Rights gives everyone the right to establish and join a trade union "to protect their interests." The European Court of Human Rights continues to refuse to interpret independent rights for trade unions into this expression. This was also done in the judgment of 6/2/1976 (Schmidt and Dahlström, grounds 34 and 36) on one of the rare legislative interventions in Swedish industrial action.

Thus, the Court did not have the same wide-ranging understanding of the freedom of association as the Committee on the Freedom of Association under the International Labour Organisation (ILO) in relation to ILO Convention 87 on the right to organise. Even if the Convention does not include a provision on action rights, the Committee on the Freedom of Association has based these rights on the fact that wage-earner and employer organisations have the right "to formulate their own programmes" (Article 3(1)).

Particularly in Denmark and Norway, there is much political interest in the question of whether the freedom of association includes a right to negotiate agreements and take industrial action. In both countries, it is broadly accepted that the government may intervene in ongoing industrial action that threatens significant societal interests. Several government interventions in Danish and Norwegian industrial actions have prompted criticism from ILO committees.

In 1994, a Norwegian trade union brought a legislative intervention against industrial action concerning the working conditions on oil rigs before the Norwegian courts, claiming that this intervention violated Sections $110 \mathrm{C}$ and 112 of the Constitution on the protection of human rights and fundamental principles of law. Among other things, the trade union referred to the fact that, in three prior legislative interventions, the government had been criticised by the ILO's complaint bodies with reference to Article 3 of Convention 87. In NRT 1997/580, the Norwegian Supreme Court rejected this criticism, since "the partially far-reaching restrictions on intervention access favoured by the ILO bodies can (not) be based on the Convention texts as negotiated and adopted." In the view of the Court, it was uncertain what could be derived from the case law of the Court of Human Rights on Article 11 of the Convention, but in any event "the Convention (...) does not contain detailed standards for the access of states to 
restrict the right to strike." Consequently, the Supreme Court found unanimously in favour of the state.

The trade union appealed the judgment to the Court of Human Rights, which in a decision on 27/6/2002 (Federation of Offshore Workers' Trade Unions and others) deemed the case inadmissible. Even if the Court did not find that the right to take industrial action was protected by the freedom of association right, it still chose to assess whether the legislative intervention, if performed, would have been necessary in a democratic society in accordance with Article 11(2). Following a thorough review of the background for the legislative intervention, the Court found that it constituted a necessary intervention in a democratic society. Unlike the ILO control bodies, the Court thus accepted that legislative intervention in industrial action may be necessary for economic reasons.

In 2008, the Court of Human Rights made one of the most striking changes of paradigms in its history by recognising the right to negotiate a collective agreement as an independently protected right pursuant to Article 11. In its judgment of 12/11/2008 (Demir and Baykara), the Court thus held against Turkey, stating that Turkey had violated Article 11 of the Convention in that a Turkish court of appeal had ruled a collective agreement in the public sector invalid and ordered the public-sector employees to repay the wage increases they had received by virtue of the agreement. The Court realised that, for a long time, it had refused to consider the right to negotiate a collective agreement as part of the freedom of association right, but nevertheless it now considered this right to be included:

\footnotetext{
"154. Consequently, the Court considers that, having regard to the developments in labour law, both international and national, and to the practice of Contracting States in such matters, the right to bargain collectively with the employer has, in principle, become one of the essential elements of the 'right to form and to join trade unions for the protection of [one's] interests' set forth in Article 11 of the Convention, it being understood that States remain free to organise their system so as, if appropriate, to grant special status to representative trade unions. Like other workers, civil servants, except in very specific cases, should enjoy such rights, but without prejudice to the effects of any 'lawful restrictions' that may have to be imposed on 'members of the administration of the State' within the
} 
meaning of Article 11(2) - a category to which the applicants in the present case do not, however, belong (see paragraphs 106-107 above)."

With this judgment, it was formally only the right to negotiate collective agreements which the Court deemed part of the freedom of association right. In a judgment of 21/4/2009 (Yapi-Yol Sen), however, the Court also recognised the right to strike as an independently protected part of the freedom of association and ruled against Turkey, which had prohibited a general strike. In a judgment of $8 / 4 / 2014$, the Court has continued this line and specified that the right to sympathy action is also protected by the freedom of association right, even if the scope of this protection in the field is slightly more ambiguous.

Consequently, both the right to negotiate collective agreements and the right to take industrial action now enjoy the special protection which comes from being an integral part of the freedom of association in Article 11(1) of the Convention on Human Rights. Any state intervention against these two rights - e.g. legislative intervention in industrial action - thus has to be "necessary" in a democratic society and may be tested by the courts and, ultimately, by the Court of Human Rights.

\section{The right to take industrial action and free movement}

The European Convention on Human Rights is not only significant to the member states, but also to the EU. With the Lisbon Treaty, the Union undertakes to accede to the Convention (Article 6(2) of TEU). Following long, complicated negotiations, an agreement was reached by the Member States and the deciding bodies in the EU and the Council of Europe on the Union's accession to the Convention. However, the European Court of Justice has refused this agreement in a statement of 18/12/2014 (2/2013), arguing that it is incompatible with the autonomy of EU law and its special characteristics.

Even though the European Court of Justice has said that the Union cannot accede to the Convention, the basis of the existing agreement does not change the fact that the institutions of the Union must respect the Convention as part of EU law (Article 6(3) of TEU). The rights specified in the Convention are also at the base of many of the rules of the EU Charter, such as Article 12 on the freedom of association. According to the explanatory notes, this provision - and Article 53(3) of the Charter - offer at least 
the same protection as Article 11 of the Convention on Human Rights in terms of freedom of association.

It is striking that the European Court of Justice does not mention Article 11 of the Convention on Human Rights or the case law of the European Court of Human Rights in its judgments of 11/12/2007 in C-438/05 (Viking) and 18/12/2007 in C-341/05 (Laval). The Court refers to a number of other international conventions and, in particular, to Article 28 of the EU Charter on the right to take industrial action, but not its Article 12 on freedom of association. Unlike Article 28 on freedom to negotiate collective agreements, Article 12 on freedom of association does contain a caveat to the effect that the right must be exercised "in accordance with Community law and national law and practices."

The failure to refer to Article 11 of the Convention on Human Rights (and Article 12 of the Charter) may be due to the fact that the Court - perhaps rightfully so - has not taken the case of the Court of Human Rights to mean that an actual right to collective bargaining and collective industrial action is associated with the freedom of association in Article 11 of the Convention. Only the Court of Human Rights judgment of 12/11/2008 (Demir and Baykara) made it clear that the right to negotiate a collective agreement constituted an independently protected element in the freedom of association. And only with the judgment of 21/4/2009 (Yapi-Yol Sen) did it become clear that freedom of association also involves a right to labour-market organisations to take industrial action.

The change of practice of the Court of Human Rights may become significant when balancing the right to take industrial action against the right to free exchange of services. According to Article 11 of the Convention on Human Rights and the case law of the Court of Human Rights, the decisive question is whether the restriction which the free exchange of services imposes on the right to take industrial action is a necessary intervention in a democratic society. This test has a different starting point than the European Court of Justice test in the Laval judgment, where the question was whether the restriction which the industrial action imposed on the free exchange of services was justified by compelling general considerations for society. It is likely that Member States must enjoy the same "wide estimate" when balancing the conflicting considerations for the right to take industrial action and the free exchange of services as they enjoy in 
other situations, where they have to balance the fundamental rights of private individuals against each other, cf. for example the judgment of 12/6/2003 in C-112/00 (Schmidberger) on the free movement of goods vis-à-vis the freedom of association in connection with a demonstration which blocked the Brenner motorway between Germany and Austria for more than 30 hours.

\subsection{Harmonisation of wages and working conditions}

\subsubsection{EU harmonisation of working conditions}

\section{Directives}

Social and labour market policies are characterised by the fact that there are largely no Treaty obligations for Member States, compared with the rules on free movement. Apart from the equal pay obligation in Article 157 of TFEU, this Treaty contains only rules that give the EU authority to adopt Directives with minimum rules, e.g. on working conditions.

In 1989, there was a principal change in the role of the EU in social and labour market policies. Eleven of the twelve existing Member States at the time adopted the Community Charter of the Fundamental Social Rights of Workers. The Charter listed a wide range of collective and individual rights for wage-earners: fair remuneration (Article 5); public placement services free of charge (Article 6); improvement of living and working conditions, especially in regard to a written contract of employment; the organisation of working time and atypical types of employment (Articles 7-9); adequate social protection (Article 10); freedom of association, collective bargaining and the right to take industrial action (Articles 11-14); equal treatment for men and women (Article 16); as well as information and consultation of workers (Articles 17-18); and satisfactory health and safety conditions at the workplace (Article 19).

The Community Charter was adopted as a "solemn declaration" and was thus not legally binding on the Member States. The Community Charter thus did not impose new obligations on Member States in itself, but for 
the EU Commission it became a political benchmark for a number of new initiatives, including proposals for new Directives.

With the Treaty of Maastricht, the eleven Member States which had signed the Community Charter gave the Union authority to adopt Directives within the field of labour law with a qualified majority as a main rule. This made it easier for labour-law Directives to be adopted. Sensitive elements, such as protection against termination, collective handling of interests and social security still required unanimity, however. Furthermore, wage conditions, the right to organise and the right to take industrial action were entirely exempted from the Union's authority. In addition, the Union was only given authority to adopt Directives with minimum requirements and the Union had to bear in mind the competitiveness of enterprises and the national differences (cf. Articles 151 and 153 of TFEU).

Approximately 15-20 labour-law Directives have been adopted (not including the many individual Directives on the working environment). Most of these Directives were adopted in the 1990s, whereas new Directives after 2000 have been few and far between. Since the Temporary Workers Directive in 2008, the EU has not adopted any new labour-law Directives, and the Commission that has just taken office does not seem to have any new proposals on the drawing board at the moment.

Labour-law Directives do not systematically harmonise working conditions at European level. Hardly any Directives on collective agreements have been adopted, which also reflects the limited authority of the EU. Conversely, a number of Directives on conditions of employment have been adopted, in particular a prohibition against discrimination and Directives on special types of employment. The most systematic regulation occurs in the field of occupational health and safety in the form of a general framework directive and a great many individual Directives.

Employment-law Directives are characterised by having to strike a complex balance between determining fundamental principles and leaving the specific detailing of generally worded principles up to the individual Member States. While the Commission and the Parliament have focused intently on general principles of law, the Council has been much more focused on national adaptations.

A general feature of the draft Directives and the adopted Directives is the fact that their recitals refer explicitly to specific rights in the Commu- 
nity Charter. The tendency towards placing Directives within a fundamental law framework has been reinforced with the Charter of Fundamental Rights. Many of the more recent Directives thus also include a clear reference to specific rights in this Charter.

The Council has deemed it important to ensure that labour-law Directives "concentrate on basic, binding principles and leave the development and transposition to the Member States individually," and that they "are flexible enough and confine themselves to provisions which can be incorporated into the various national systems" (Council Resolution of $6 / 12 / 1994$ on certain aspects for a European Union social policy, chapter I, item 17). Many of the Directives thus leave it up to Member States to adapt the generally worded rules in the Directives to the special conditions on the labour market in the individual Member State.

The dilemma between general principles and national detailing is clear, for example in Article 7 of the Working Time Directive (now Directive 2003/88). On the one hand, Member States must ensure "that every worker is entitled to paid annual leave of at least four weeks," but on the other, this to be done "in accordance with the conditions for entitlement to, and granting of, such leave laid down by national legislation and/or practice."

\section{European agreements}

From a Nordic perspective, one important element of the Maastricht Treaty was that the Union's authority to adopt Directives was subjected to a special consultation and agreement system involving the social partners at European level. The Commission was now obliged to consult the social partners at European level before presenting proposals for Directives, and the social partners became entitled to take over the further processing with the aim of concluding an agreement. The social partners can decide if they want to carry out a possible agreement themselves or ask the Council to do it (cf. now Articles 154-155 of TFEU).

In its resolution of $6 / 12 / 1994$, the Council emphasised the importance of involving the social partners with a view to finding "pragmatic solutions". For example, the Council asked the social partners "to make use of the possibilities for making agreements, since they are as a rule closer to social reality and to social problems" (Chapter II, item 3). 
The European social partners concluded three general framework agreements in the 1990s, which were subsequently implemented via Directives on parental leave (Directive 96/34, subsequently replaced by Directive 2010/18), part-time work (Directive 97/81) and fixed-term employment (Directive 99/70). These agreements use a traditional rights terminology, but allow a flexible framework for national adaptations. The recitals for the agreements on part-time work and fixed-term employment state, for example, that it is up to the Member States and the social partners to implement the general principles "while taking account of conditions in the individual Member State and the special circumstances of specific sectors and industries".

The European social partners also concluded a number of general framework agreements in the '00s, but they are of a softer nature than the framework agreements in the preceding decade. These are framework agreements on telework (2002), stress prevention (2004), bullying and violence in the workplace (2007), and an inclusive labour market (2010). All these agreements have been implemented by the parties themselves and are characterised by focusing on "guidelines" rather than "rights and duties".

There is a major difference between the legal status of the agreements implemented through a Directive and the agreements implemented by the social partners themselves. An agreement implemented through a Directive has the same binding effects on Member States as other Directives. The Commission may raise concerns in the case of lacking or inadequate implementation, and the European Court of Justice may pass preliminary rulings on the interpretation of agreement-based Directives. The agreements implemented by the social partners themselves do not bind Member States, so the Commission is not able to raise concerns in the case of lacking or inadequate national implementation. By the same standard, the European Court of Justice does not have the authority to interpret independent framework agreements. 


\subsubsection{Implementation in the Nordic countries}

\section{Implementation requirements of EU law}

According to Article 288 of TFEU, an EU Directive is directed at the Member States, which are obliged to achieve the objective of the Directive, but are free to choose the form and means. The fact that this provision imposes the overall responsibility for implementation of directives on the state poses a principal challenge to the Nordic countries, since this may shift the general balance between the legislature and the social partners.

Back when the first labour-law Directive - the Equal Pay Directive from 1975 - was implemented, the European Court of Justice ruled against the Danish state, stating that Denmark had implemented the Directive inadequately, cf. the judgment of $30 / 1 / 1985$ in C-143/83 (the Commission versus Denmark). According to the Court, the Danish state was free to leave it up to the social partners to implement the Directive, but the state could not free itself from its obligation to ensure that all workers enjoyed the protection of the Directive. The fact that the Act restricted the equal pay obligation to "same work", even if collective agreements and industrial court case law specified that this expression also included "work of the same value", was incompatible with the Treaty.

The Danish and Swedish states attached great importance to the specific implementation rule for labour-law Directives which was introduced in the Maastricht Treaty (now Article 153(3) of TFEU). According to this provision, a Member State may leave it up to the social partners to carry out labour-law Directives if so requested. In such case, the Member State must ensure that the social partners have introduced the necessary provisions via an agreement no later than the date on which the Directive has to be implemented, "in that measures must be taken so as to ensure, at any given time, the results prescribed in the Directive concerned."

While the social partners in Sweden do not seem to have attached major significance to implementation by agreement, a (unilateral) implementation by agreement of the labour law provisions of the Working Time Directive (daily breaks, maximum weekly working hours, nighttime work) played a crucial role for the social partners in Denmark. The government chose - with broad backing from a majority of parties in the Danish Parliament (Folketinget) - not to put forward a subsequent Bill with the aim of covering the (modest) residual group of wage-earners 
who were not covered by collective agreements. The majority argued that the vast majority of all wage-earners were covered by collective implementation agreements and that the agreements would have a knock-on effect on the small residual group, and also that the social partners had pledged to seek a resolution to any dispute arising in relation to the Working Time Directive (report of 18/12/1996 from the Labour Market Committee of Folketinget).

After the Commission had raised concerns about the implementation in a letter of formal notice and in a reasoned opinion, the Danish government - with the support of the social partners - chose to implement an Act on implementation of parts of the Working Time Directive. The Danish social partners thus actually accepted that, as a minimum, implementation requires that supplementary legislation be introduced to cover wageearner groups not covered by the collective agreements.

\section{Implementation models of the Nordic countries}

\section{a) Finland and Norway}

In Finland and Norway, the implementation of EU Directives has not given rise to any major, principal discussions. Finland and Norway are different from the other Nordic countries in that they have more systematic legislation on employment conditions in their Acts on work agreements and on the working environment respectively. Most of the labour law Directives have been implemented via these general employment Acts.

The general arrangements with generally applicable collective agreements have not played a role in connection with the implementation of labour law Directives. The Norwegian arrangement does not have the general aim of broadening wages and working conditions from representative collective agreements to all employers and wage-earners within a given industry, but rather the aim of preventing social dumping by giving foreign wage-earners wages and working conditions equivalent to those of Norwegian wage-earners. The Finnish arrangement has the aim of extending collective agreement wages and working conditions to all employers and wage-earners within a given industry, but does not cover all parts of the labour market. Implementation of a labour-law Directive via generally applicable agreements will thus not cover all relevant wage- 
earners in the Finnish labour market and will thus not in itself comply with EU law requirements concerning correct implementation.

The implementation of labour law Directives has not given rise to thorough changes to the labour law systems of Finland and Norway. The balance between legislation and collective agreements has not shifted markedly in favour of (more) legislation. Primarily, implementation has given rise to a revision of existing legislation and collective agreements, e.g. so as to adapt the rules to the Directives on part-time work, fixed-term employment and temporary workers. Both countries seem to have taken the stance that the implementation of Directives should give rise to the smallest possible number of changes to existing rules.

In both countries, the political-administrative system seema to have played a dominant role, yet implementation generally occurred in close dialogue with the social partners. To a certain extent, this cooperation has unfolded within the framework of formalised tripartite bodies for EUrelated questions.

The Finnish and Norwegian employment legislation primarily lay down mandatory minimum rules. The rules of the laws cannot be derogated from to the detriment of wage-earners in individual contracts of employment or collective agreements. This basic principle has also been the predominant guideline for the implementation of labour-law Directives. Consequently, in both countries the legislation stipulates the minimum level which is to apply within the remit of the Directives.

To a varying extent, the social partners supplement statutory rules in both countries, depending on the relevance of the given Directive in relation to existing collective agreements. For example, the Directives on parttime work and fixed-term employment have prompted the adjustment of a number of collective agreements in light of the principle of equality on which the Directives are based.

\section{b) Denmark, Iceland and Sweden}

In Denmark, Iceland and Sweden, the implementation of labour-law Directives has been a bigger challenge than in Finland and Norway. It has not been possible to the same extent to implement the Directives in existing employment laws. As the predominant rule, the Directives have given rise to new, independent legislation. 
In both Denmark and Sweden, the ongoing implementation of Directives has led to a marked growth in the number of new employment laws. On the other hand it is striking that new employment laws are largely restricted to laws based on EU Directives in both countries. Furthermore, it is a characteristic feature of the implementation laws that they largely implement the minimum conditions of the Directive and that they are of a semi-dispositive nature. The collective agreement does not have to observe the minimum conditions of the legislation, but those of the Directives. This gives the social partners a (slightly) freer negotiating position than they have in accordance with Finnish and Norwegian implementation legislation. The legislative technique is common in Denmark in particular.

The social partners have played different roles in Denmark and Sweden in connection with the implementation of labour law Directives. In both countries, the legislature has involved the social partners in the implementation process on an ongoing basis, but the influence of the social partners has varied considerably.

In Sweden, employers in particular have not wished to implement Directives via collective agreements to any large extent. Implementation has thus been handled predominantly by expert committees and the ministries. The social partners have been given regular opportunities to present their views, but they have often taken a different view of the measures required. Consequently, the statutory rules implemented were controversial in many instances, and follow-up collective agreements have been few and far between.

In Denmark, the social partners have shared the wish to implement the Directives via agreements to the greatest extent possible. In an agreement from 1996, the employers in DA and the trade unions in LO encouraged the Minister for Employment to pass on Directives to the social partners' umbrella organisations and advised against any kind of competing Bills of Parliament or political statements while the social partners negotiated implementation through collective agreements. Another important element in DA's and LO's implementation agreement was to establish a committee to give ongoing advice to the Minister for Employment in the implementation process. The Ministry of Employment established an implementation committee in 1999 as a joint forum for the continual discussions between the government and the social partners on the implementa- 
tion of Directives. The committee has not only helped ensure that the social partners have been allowed to negotiate implementation through agreements without political interference. It also granted the social partners substantial influence on the Bill of Parliament subsequently prepared to cover jobs not covered by an implementation agreement.

The difference between the Danish and Swedish implementation practices should perhaps also be seen in light of the fact that the Danish social partners have had a stronger incentive to reach agreement on implementation through collective agreements. When a Directive is implemented through agreements, the social partners move the solving of conflicts from the ordinary courts (conflicts on legislation) to the industrial courts (conflicts on collective agreements) with the mutual advantages this entails. Implementation through collective agreements is not necessary in the same way in Sweden, since the Industrial Court - as the only one in the Nordic countries - has a general authority to deal with labour law disputes, no matter if they arise from a collective agreement or from legislation.

Unlike Denmark and Sweden, Iceland has a model which makes it possible to broaden collective agreement wages and working conditions to all employers and wage-earners in a given industry. However, like the Finnish model, this model has not played a prominent role in connection with the implementation of labour-law Directives. Only the Part-time Directive has been implemented using the model of generally applicable collective agreements. On the other hand, the social partners have played a prominent role in the implementation process and have had decisive influence on the contents of implementation laws. The general pattern thus resembles the pattern characterising implementation in Denmark and Sweden. The Icelandic social partners - like the Danish social partners - have shared a wish to handle Directives through their own collective agreements, so a great many supplementary collective implementation agreements have been concluded. 


\subsubsection{Interpretation and use of EU rules}

\section{The operative interpretation style of the European Court of Justice}

A special feature of the rules based on Directives is that their interpretation must continually take account of the interpretation of the Directives by the European Court of Justice (and the EFTA Court). The European Court of Justice is the ultimate interpreter of EU law and national courts are able to submit preliminary references on the interpretation of Directives to the European Court of Justice (Article 267 of TFEU). A striking feature of the case law developed by the European Court of Justice is that the Court has widely promoted a more uniform understanding and use of the Directives than can immediately be read from the wording of the Directives.

To an increasing extent, the European Court of Justice emphasises that the Directives have the general purpose of improving living and working conditions at an ever increasing level and that the Directives specify fundamental rights in the Community Charter of Fundamental Social Rights and the Charter of Fundamental Rights. Further to this, the European Court of Justice has classified a number of Directive rules as "particularly important principles in the EU's social legislation." The first time this was done was in the judgment of 26/6/2001 in C-173/99 (BECTU) on the right to four weeks' paid leave pursuant to Article 7 of the Working Time Directive. This approach to the provision led the Court to focus in particular on the right to four weeks' paid leave, while downplaying the reference stating that this should be done in accordance with national legislation and practices. On this basis, the Court has stated, among other things, that a Member State cannot let the wage-earner bear the risk of an illness occurring during holidays. In this case, too, the wage-earner is entitled to be granted compensatory holiday leave, cf. for example the judgment of 21/6/2012 in C-78/2011 (ANGED).

This case law would seem to go in the opposite direction of the European Court of Justice judgment of 12/2/2015 in C-396/13 (Elektrobudowa), which stressed that specification of the concept of minimum wages in Article 3(1) of the Posting of Workers Directive was left up to the host country in accordance with the wording of that provision. Contrary to the labourlaw Directives, however, the Posting of Workers Directive does not aim to harmonise, but only to coordinate national arrangements. 
The European Court of Justice has also taken an objectives-and-rightsoriented interpretation style as regards the labour-law Directives which implement framework agreements between the social partners at European level. By having an agreement implemented via a Directive, the social partners - including the employers - thus accept the Court's general interpretation paradigm, which focuses on interpreting main principles in a widening perspective, and exceptions and references to national practices in a narrowing perspective. When negotiated Directives are interpreted, it plays no role in this interpretation that the autonomy of the social partners has been laid down in Article 152 of TFEU and the right to negotiate collective agreements in Article 28 of the Charter. In its judgment of 16/9/2010 in C$149 / 10$ (Chatzi), the Court turned down detailed argumentation from the German government in favour of interpreting agreement-based Directives while respecting the autonomy of the social partners.

The Court has considered Article 4 on equal treatment of part-time workers and fixed-term workers in the agreements on part-time work and fixed-term employment as an expression of "social law principles at Community level, which cannot be interpreted restrictively," cf. the judgment of 15/4/2008 in C-268/06 (Impact) and the judgment of 10/6/2010 in C-395/08 (Bruno and Pettini). Similarly, the Court has deemed Article 2 (6) on wage-earners acquired rights during parental leave as an expression of "a particularly important principle in Community social legislation, which can thus not be interpreted restrictively" cf. the judgment of $22 / 10 / 2009$ in C-116/08 (Meerts). It is striking that the Court finds no support for the nature of the rules as "important social law principles" in the agreements between the social partners themselves, but exclusively or predominantly in the recitals of the Directives and the Treaty framework, on which the social partners have had no influence.

\section{Division of work between European and national courts}

Both European and national courts have an important role to play in ensuring that Member States comply with the rules of EU law.

The Commission and the EFTA Surveillance Authority may take a Member State to the European Court of Justice and the EEA Court, if the Member States does not comply with its obligations (Article 258 of TFEU). Prior to this, an administrative complaint procedure vis-à-vis the Member State must have been completed, so as to allow the Member State the op- 
portunity to explain and defend its legal position. The administrative procedure constitutes "an essential guarantee required by the EC Treaty in order to protect the rights of the Member State concerned," cf. the judgment of 5/6/2003 in C-145/01 (The Commission versus Italy).

As part of processing a court case, any national court may submit preliminary references about the interpretation of the Treaties and the validity and interpretation of legal acts issued by Union institutions. The task of the European Court of Justice and the EFTA Court in a preliminary ruling is to interpret EU and EEA rules, while the national court will decide the specific case on the basis of the interpreted rules. In practice, however, this division of work is blurred, since for example national courts often ask for an assessment of whether a specific national state of law is compatible with EU law or EEA law. The European Court of Justice has been very accommodating in replying to submissions of this nature and has also specified that a Member State has the same right to correct its national state of law to match a prejudicial judgment, as it has in case of a judgment for breach of a Treaty, cf. for example the judgment of 21/6/2007 in C-231/06 (Jonkman).

This development not only influences the division of work among the courts, but also makes it more difficult for the Member State to define its national legal position, because the preliminary reference procedure does not provide the procedural safeguards which are associated with a formal infringement procedure. A preliminary reference is a dialogue between a national and a European court and it is the national court making the reference which prepares the reference, including the questions to the European Court of Justice. The Member State can only cater for its interests through its pleadings in the case just like other Member States.

In Denmark, the courts were reluctant to make this type of reference for the first many years, but it has become more common to do so in recent years. The Danish Supreme Court, however, has made a number of recent decisions in which it has refused a request from a party to submit questions with the aim of having the European Court of Justice to verify whether a Danish legal position is compatible with EU law.

In a ruling of 16/3/2012 (U2012.2033H), the Danish Supreme Court thus refused to ask the European Court of Justice whether Article 6(1) of the Employment Equality Directive prevented a rule in the Discrimina- 
tion Act which makes it possible for the parties to a collective agreement to permit lower pay for young people under the age of 18 . The rejection was based on the principal reason that it is "up to" the Supreme Court to assess whether the disputed national legal position was compatible with the Employment Directive and the Supreme Court "will include the guidelines to be derived from the case law of the European Court of Ju stice." In a subsequent judgment of 14/11/2013 (U2014.470H), the Supreme Court found in favour of the claim by the private enterprise and the Ministry of Employment and against the claim of the HK trade union which was that the 18-year rule was incompatible with the Employment Equality Directive. This was done following a thorough review of the relevant criteria for legitimate differentiation on the basis of age in Article 6(1) of the Employment Directive.

In subsequent cases as well, the Supreme Court has refused to ask the European Court of Justice whether specific Danish rules are incompatible with EU law, stating that this assessment is a task for the Danish courts, and that these will involve the general guidelines to be derived from the case law of the European Court of Justice. For example, the Supreme Court refused to meet a request from LO, the Danish Confederation of Trade Unions, concerning a question of whether the free movement of workers prevented a rule in the Act on a Danish International Ships Register which gives DIS-registered ships the right to use foreign crews working under the wage and working conditions of their home country (ruling of 20/3/2012, U2012.2052H). The Eastern Division of the High Court had found in favour of the Ministry of Employment and against LO's claim; LO chose to withdraw its appeal after the Supreme Court had refused to submit a prejudicial question to the European Court of Justice.

This clear statement on the division of work is striking - also in a Nordic context - but is in line with the division of work laid down in Article 267 of TFEU, which only grants the European Court of Justice authority to "interpret" EU legal acts. Conversely, this new line puts the Supreme Court at odds with the European Court of Justice. In a judgment of 12/10/2010 in C-45/09 (Rosenbladt), the European Court of Justice thus disallowed an objection from the Irish government, stating that the Court did not have the authority to assess whether the Employment Directive prevented a 
German rule on automatic retirement at the age of 65 . According to the Irish government, this was a case of use - not interpretation - of EU law, but the European Court of Justice did not agree.

\section{Obligation of national courts to interpret in conformity with EU law}

According to the case law of the European Court of Justice and the EFTA Court, national courts are obliged to interpret national rules in conformity with underlying Directives (and other EU and EEA law). The European Court of Justice describes its obligation as meaning that "to the widest possible extent" the national courts must interpret national rules in accordance with EU law using "interpretation methods recognised" in national law. Interpretation in accordance with EU law is also restricted "by general principles of law" and "cannot serve as the basis for an interpretation of national law contra legem," cf. for examples grounds 25 and 27 in the judgment of 24/1/2012 in C-282/10 (Dominguez). The general principles of EU law comprise such items as the principle of legal certainty and the principle of the protection of legitimate expectations.

The obligation to interpret in conformity with EU and EEA law constitutes a challenge for Nordic courts, which have a long tradition of focusing on the wording of and interpretative notes to specific provisions. The courts deem the interpretative notes to an Act as a binding source of law, not just a possible supportive argument in favour of a result which they happen to consider correct. A political majority may thus rest assured that the courts will respect the statements concerning the understanding of the rules which are given in the political process. By the same token, the social partners can rest assured that the political compromises which they may have taken part in making in connection with the interpretative notes are respected by the courts.

The substantial importance attached to the interpretative notes is not only significant for the political decision-making process. It also helps make it easier for both wage-earners and employers to know their legal position in advance. While the statutory rules are often described in a general - and perhaps vague - wording, the interpretative notes usually give a more detailed, reliable guidance. The possibility of acquiring more reliable guidance on the contents and scope of an Act by reviewing the interpretative notes also plays an important role for trade unions and employer federations when they advise their members. 
The Nordic courts have generally used EU and EEA law loyally and endeavoured to interpret national rules in accordance with EU and EEA law. There are few examples of cases in which a Nordic court has refused to interpret a national rule in accordance with EU or EEA law, in cases where such interpretation has not been possible within the framework of recognised interpretation principles in national law. There are a number of clear examples, e.g. from Danish case law, of the courts having disregarded interpretative notes as an element in an interpretation according to EU law, cf. for example the Industrial Court judgment of 26/1/2011 (case 2009.469), which considered municipal civil servants to be covered by the Transfer of Undertakings Act, even if according to the interpretative notes and standard practices they were not covered by the remit of said Act.

For the first time, the Danish Supreme Court refused to make an interpretation in accordance with EU law in its judgment of 18/12/2013 (U2014.914H) on Section 13 of the Holiday with Pay Act regarding compensation holiday leave in case of illness, which turned out to violate the interpretation of the European Court of Justice of Article 7 of the Working Time Directive. This provision was amended by Folketinget with effect going forward; however, on behalf of a member, the trade union umbrella organisation CO-industri claimed compensation holiday leave for illness occurring during a holiday before the Act came into force. The Eastern Division of the High Court agreed that the wording of Section 13 did not exclude interpretation in accordance with EU law; however, the Supreme Court found in favour of the enterprise. The Supreme Court found it important that the legal position was clear (in particular in the form of clear interpretative notes and long-standing administrative practice); that it would not be possible using recognised interpretation principles in Danish law to interpret in accordance with EU law; and that the principle of legal certainty and principle of the protection of the legitimate expectations would suffer if the risk of illness occurring during a holiday were to be imposed on a private employer.

In a subsequent submission ruling of 22/9/2014 (C-114/14 - Ajos), the Supreme Court stated that it is also not possible to interpret Section 2 a (3) of the Danish Salaried Employees Act in accordance with EU law; this Section deprives a salaried employee of the right to severance pay in case the person "is going to receive" old-age pension from the employer. In a 
judgment of 12/10/2010 in C-499/08 (Ole Andersen), the European Court of Justice found that this provision was incompatible with the prohibition in the Employment Directive against age discrimination to the extent a salaried employee temporarily waives his right to an old-age pension in order to pursue a work career. The Advocate-General has emphasised that it was possible to interpret this provision in accordance with EU law, since the case law used a restrictive interpretation. However, in its submission ruling, the Supreme Court stated that it is not possible to interpret the provision in accordance with EU law because of a standard understanding in case law.

With this refusal to interpret in accordance with EU law, the Supreme Court faced the principal problem of whether the Court should apply the EU law prohibition against age discrimination with direct effect on a private employer in accordance with the controversial judgments of the European Court of Justice on 21/11/2005 in C-144/04 (Mangold) and 19/1/2010 in C-555/07 (Kücükdeveci). According to these EU judgments, the general EU principle, which prohibits discrimination due to age, and which has been specified in the Employment Directive, has a direct impact on disputes with private employers and takes precedence over any conflicting national legislation. The High Courts and the Maritime and Commercial High Court had applied this principle with direct effect in a number of judgments, but initially the Supreme Court chose to submit two questions to the European Court of Justice.

Firstly, the Supreme Court wanted to be certain that Section 2(a)(3) of the Salaried Employees Act is not just incompatible with the Employment Directive - as stated in the Ole Andersen judgment - but also with the general EU law principle of prohibiting age discrimination. Secondly, the Supreme Court wanted the European Court of Justice to explicitly address the question of balancing the equal treatment principle against the legal certainty principle and, in particular, the question of whether Danish courts are allowed to attach more importance to the legal certainty principle than the equal treatment principle, which would mean that the court would find for the private employer. The submission ruling states indirectly that the submission is to be seen in the light of extensive criticism directed at the judgments of the European Court of Justice, also from several of its own Advocate-Generals. 


\subsection{Flexicurity as an employment policy guideline}

\subsubsection{Reforms of the European labour market}

Along with the harmonisation of working conditions, the EU has increasingly been given the task of coordinating the employment policies of the Member States. Contrary to social policy, employment policy does not aim to lay down minimum rules, but wishes to encourage Member States to carry out reforms of their national labour markets.

Member States are obliged to work for a coordinated strategy for employment, one of the purposes being to promote "a skilled, trained and adaptable workforce and labour markets responsive to economic change" (TFEU, Article 145). The European Council lays down the overall guidelines for employment, which Member States are then to integrate into their own employment policies. Each year, the Council reviews a report from each member country on the most important employment policy measures and is able to give recommendations to the individual country by qualified majority (TFEU, Article 148).

The guidelines adopted by the Council must be in accordance with the overall economic-political guidelines (TFEU, Article 121(2), Articles 146(1) and 148(3)). The Union's economic policy rests on "close coordination of Member States' economic policies" (TFEU, Article 119). The Union promotes such coordination in that the Council - following prior discussions in the European Council - adopts a recommendation on the overall guidelines for the economic policy of the Union and its Member States. Furthermore, the Union must monitor whether the economic development in each Member State runs according to the overall guidelines. Following a proposal from the Commission, the Council may give individual Member States recommendations (TFEU, Article 121).

Since 2005, there has been close coordination of the economic and employment-related guidelines as part of a strengthened effort to promote growth and employment. Since 2011, reporting has been done within the framework of the European Semester with the aim of ensuring stricter European management of such monitoring.

The European Semester is held on a basis which includes the Council recommendation of $13 / 7 / 2010$ on overall guidelines for the economic 
policies of Member States and the Union, as well as the Council decision of $21 / 10 / 2010$ on guidelines for the employment policies of Member States. A number of the guidelines are directed at matters of interest to the labour-law systems of Member States.

Employment guideline no. 7 thus states that Member States should work to increase labour market participation, reduce unemployment and ensure better job quality. The explanatory comments on the guideline state, among other things, that Member States should "introduce a combination of flexible and reliable contractual arrangements, active labourmarket policies, effective lifelong learning, policies to promote labour mobility, and adequate social security systems to secure labour market transitions accompanied by clear rights and responsibilities for the unemployed to actively seek work." Member States should also "together with the social partners pay adequate attention to flexicurity at the workplace."

Several sets of rules are directed especially at the euro countries and EU countries which adopt the guidelines on a voluntary basis. This applies for example to the Euro Plus Pact - stronger coordination of economic policies with the aim of increasing competitiveness and convergence (the Competitiveness Pact). The participating Member States commit themselves to taking all the measures required to promote competitiveness and employment, contribute further to sustainable finances and strengthen financial stability. It is up to each country to decide the political measures to be taken, but the Pact indicates a number of areas of particular relevance. As regards the point concerning "promotion of competitiveness", special attention will be paid to "measures to ensure a cost development in line with productivity, while respecting national traditions of social partner dialogue and relations." As regards the point about "promotion of employment", the focus will be on "labour market reforms to promote flexicurity".

\subsubsection{Reform recommendations for the Nordic countries}

Employment-related guidelines and the pertaining monitoring procedure within the framework of the European Semester are only binding for Denmark, Finland and Sweden. Employment policies did not become part of European cooperation until the Amsterdam Treaty, so they are not 
comprised by the EEA Agreement. Only Finland, being a euro country, is directly committed by the strengthened cooperation with a framework that includes the Euro Plus Act. However, Denmark has chosen to join this strengthened cooperation.

As an element in the European Semester, the Council - following a proposal from the Commission - usually issues recommendations to Member States in accordance with Articles 121 and 148 of TFEU. Basically, the Council will support the Commission's proposal, but it may choose to disregard the proposal or design it differently. If the Commission disagrees with the proposed changes, the Council must explain its stance in an official note.

The recommendations received by the Member States from the Council are not legally binding (TFEU, Article 288). The individual Member State is thus at considerable liberty to choose how it will most appropriately address the recommendation.

A number of countries have received recommendations to make their wage systems more flexible, so as to create a better link between wage development and productivity development. The Council has also made recommendations to a number of countries to make their protection against termination of employees more flexible. These recommendations address such issues as relaxing protection against termination of permanent employees and making it easier to use flexible types of employment. The amendments of national law to which such recommendations may give rise probably do not resemble "implementation of EU law", which means that the European Court of Justice is able to verify whether there is compliance with the Charter of Fundamental Rights, cf. the judgment of 21/10/2014 in C-665/13 (Sindicato Nacional dos Profissionais de Seguros e Afins) on suspension of holiday and Christmas supplements for public sector employees in Portugal, as well as the judgment of 5/2/2015 in C117/14 (Poclava) on easing termination rules in Spain.

Denmark, Finland and Sweden have also received recommendations aimed at their employment policies, but these have been more modest than the recommendations received by many other European countries. In the spring of 2012, however, a more serious recommendation to the Swedish government was in the offing, but following objections from Sweden the end result was more moderate. 
On 30/5/2012, the Commission proposed that Sweden should make its wage system more flexible and ease its protection against termination in the form of more lenient access to probationary employment (COM (2012) 328). The proposal had the following wording:

\begin{abstract}
"Take further measures to improve the labour market participation of youth and vulnerable groups by focusing on effective active labour market policy measures, encouraging increased wage flexibility, notably at the lower end of the wage scale, and reviewing selected aspects of employment protection legislation like trial periods to ease the transition to permanent employment. Review the effectiveness of the current reduced VAT rate for restaurants and catering services in support of job creation."
\end{abstract}

The Swedish government spoke out strongly against this proposal, one of the reasons being that wage negotiations are a matter only for the social partners on the Swedish labour market. The Council went along way to accommodate the Swedish objections, resulting in a more modest recommendation of 10/7/2012 (OJ C 219/2012, p. 85):

\begin{abstract}
"Improve the labour market participation of youth and vulnerable groups, e.g. by improving the effectiveness of active labour market measures, facilitating the transition from school to work, promoting policies to increase demand for vulnerable groups and improving the functioning of the labour market. Review the effectiveness of the current reduced VAT rate for restaurants and catering services in support of job creation."
\end{abstract}

The Council thus removed its recommendations of more wage flexibility and less-restrictive protection against termination. However, the Commission did not agree with this change, so the Council had to make the following public statement giving its reasons for the change $\mathrm{O} O \mathrm{~J} \mathrm{C}$ 219/2012, p.101): 
"The Council agreed to adjust the text so as to better reflect the actual challenges of the Swedish labour market; i.e. improve the effectiveness of ALMPs, transition from school to work and government policies to increase the demand for vulnerable groups on the labour market.

In addition, the Council recognised that Sweden has a decentralised wage bargaining framework and concurred that social partners are responsible for wage bargaining and that government interference in the process would not be in line with the national system for wage formation. The reference to 'encouraging increased wage flexibility' was therefore considered inappropriate."

Also on 29/5/2013, the Commission made a proposal for a recommendation to Finland, urging Finland to adapt the development of real wages to productivity development in a dialogue with the social partners (COM (2013) 376). Despite objections from the Finnish government, the recommendation was included with the same wording in the Council recommendation of 9/7/2013 (OJ C 217/2013, p. 24). The Commission has not proposed a similar recommendation in 2014.

Even if these are only recommendations - and the framework is more flexible than in the case of a Directive - it is politically sensitive for Nordic governments to receive recommendations to make wage systems more productivity-oriented. In the Nordic systems, it is not a task for the state to order the social partners on the private labour market to introduce more productivity-oriented wage systems. The very fact that the Council designs country-specific recommendations while respecting the autonomy of the social partners, as specified in Article 152 of TFEU, as well as their right to negotiate collective agreements in Article 28 of the Charter is also an important factor in terms of the Nordic countries.

It will also become a politically sensitive question for the Nordic countries if employment policies are to be used to promote the ideas about a European minimum wage, which Commission President Jean-Claude Juncker mentioned when he took office. A coordinated effort to introduce general minimum wages in all EU countries may be compatible with the general employment-related objectives defined in Article 145 of TFEU, but it will be a challenge to the Nordic countries which give priority to free wage bargaining between the social partners. 


\subsection{General development trends in European influence}

\subsubsection{Increasing complexity of the European law system}

As can be seen in the preceding analyses, the European law system, epitomised by the EU and EEA, is complex. The Union has broad authority to adopt rules; it has adopted many rules aimed at the labour market, and there is a steady flow of rulings from the European Court of Justice and the EEA Court. At the same time, EU and EEA law interacts more and more intensively with the European Convention on Human Rights, which even has its own judicial control in the form of the European Court of Human Rights.

The Member States gave authority to the Union to adopt rules on working conditions and other work-related matters in connection with the Maastricht Treaty; however, one important element of the political compromise was to keep wage matters and the right to take industrial action outside the authority of the Union. Thus, the Union may not adopt labour-law Directives on minimum wages or the exercise of industrial action rights. However, it has subsequently become apparent that industrial action may constitute an unjustified restriction on the right to freely establish a business and exchange services. It has also become apparent that the Union is able to recommend that Member States carry out reforms of their wage systems within the framework of the coordinated economic and employment-related policy. The fact that the Union is incompetent in relation to one legal basis does thus not exclude it from acting in accordance with another legal basis.

The different bases for authority do not address the same issues. While social policy aims mainly to improve living and working conditions by designing joint minimum conditions, employment policy aims predominantly to improve employment through the introduction of national labour market reforms. These two different objectives may give the impression that, on the one hand, the EU orders Member States to introduce ever higher (joint) minimum conditions for working conditions across the Member States, while, on the other hand, the EU also endeavours to get Member States to ease existing protections in their national labour-law systems. 
The Union not only adopts rules pursuant to different bases of authority, these rules also form part of a complex hierarchy of laws in the individual areas. The right to free exchange of services has been established both in the EU Treaties and the EEA Agreement, but has also been detailed in a number of Directives, including the Posting of Workers Directive, which also applies to Iceland and Norway. This Directive went through a complicated political process and appears to be a compromise between conflicting interests - promotion of the free exchange of services, protection of posted wage-earners, and prevention of social dumping in host countries. According to Article 3 of the Directive, determination of a minimum wage is left up to the legislation and practices of the host country. The duality of the legal basis - Treaty rules and Directives - has, however, given rise to uncertainty as to who actually determines the level of minimum wages. Is this - as stated in the Directive - left up to the Member States or can the EU and EEA Courts subject national minimum wage arrangements to censorship in pursuance of the general principles of free exchange of services in the EU Treaty and the EEA Agreement?

This question has not become less complicated by the fact that two theoretically independent - European Courts have taken different approaches to the question. In its judgment of 23/1/2012 in E-2/11 (STX), the EFTA Court stated that the minimum wage must be compatible both with Article 3 of the Directive and Article 36 of the EEA Agreement. A national minimum wage which is compatible with Article 3 of the Directive may - according to the judgment - very well constitute an unjustified restriction of the Treaty-based right to the free exchange of services. However, in its judgment of 12/2/2015 (Elektrobudowa), the European Court of Justice only addressed a number of wage elements in accordance with Article 3 of the Directive, not including Articles 56 and 57 of TFEU, even if the Advocate General had taken a critical stance on some of these wage elements on the basis of Treaty law principles. With this judgment, the European Court of Justice sent a clear signal, stating that determination of minimum wages is a matter for the host country, but on the other hand it did not explicitly rule out the possibility that elements of a nationally determined minimum wage may constitute an unjustified restriction on the free exchange of services. 
Even more complicated is the question of the right of trade unions to take industrial action in order to achieve (better) wages and working conditions for posted wage-earners. In its judgment of 18/12/2007 in C341/05 (Laval), the European Court of Justice considered trade-union action to constitute an unjustified restriction of the free exchange of services. However, subsequent Swedish legislation has been criticised by complaint bodies under the ILO and the Council of Europe for violating the right to take industrial action. It is uncertain how the European Court of Human Rights will view this issue, but in its judgment of 12/11/2008 (Demir and Baykara), it established a new human rights framework for the right to negotiate collectively and take industrial action. Even if the EU Treaties, the Convention on Human Rights and the Social Charter constitute different legal frameworks, each with separate monitoring bodies, they are entering into ever closer interaction. According to the EU Treaties, the Union respects both the Convention on Human Rights and the Social Charter (cf. for example the preamble to and Article 6 of TEU).

Labour-law Directives do not give rise to the same immediate, complicated interaction with Treaty rules as is the case of the Posting of Workers Directive. The EU Treaties only oblige Member States to introduce the principle of equal pay for men and women, but heads of state and government have established that a number of working conditions are fundamental rights in the Charter declared as part of the Nice Treaty and subsequently given the same legal value as the Treaties of the Lisbon Treaty. A number of the labour-law Directives reflect this development in the form of explicit references to the Community Charter on the fundamental rights of wage-earners and the Charter of Fundamental Rights.

The interaction of the labour-law Directives notably with the Charter makes it more difficult to predict the scope of the obligations resulting from each Directive. It has been important for a growing number of Member States with increasingly varied labour-market systems to ensure wide access to adapting the general principles of the Directives to the conditions of the individual Member State. This is clearly reflected, for example, in the Directives on the organisation of working hours, as well as on parttime work, fixed-term employment and temporary work. However, the European Court of Justice has interpreted a number of the rules of the 
Directives as detailing the fundamental rights, e.g. in the Charter of Fundamental Rights.

Article 7 of the Working Time Directive on four weeks' paid leave has been interpreted in light of Article 8 of the Community Charter and Article 31(2) of the Charter of Fundamental Rights. This provision has been classified as a "particularly important principle of the EU's social legislation," which means that the European Court of Justice has largely disregarded the fact that the four weeks' leave should be detailed in accordance with "the criteria for achieving and allocating such leave as are laid down in national legislation and/or practices." Consequently, the specific detailing of the rule of the Directive becomes less of a matter for the individual Member State and more of a matter for the European Court of Justice and the EFTA Court. This also makes it more difficult for Member States to predict the obligations resulting from Article 7 of the Working Time Directive.

The European Court of Justice has taken a corresponding, rightsoriented interpretation approach to the Directives which launch framework agreements between the social partners at European level. By having an agreement implemented via a Directive, the social partners thus accept that the main principles of the agreements will be interpreted more broadly and that exceptions and reference to national practices will have a narrowing interpretation. The wide-ranging national flexibility encouraged in particular by the Directives on part-time work and fixed-term employment has thus not been reflected in the European Court of Justice's interpretation of the Directives. It is natural to assume that this approach to the interpretation of social-partner agreements will not strengthen the incentive of the social partners (particularly as regards the employers) to enter into framework agreements with the aim of subsequent launching through Directives.

\subsubsection{Changed balance between legislation and collective agreements}

A striking feature of the impact of European rules is the fact that the legislature has gained a more prominent role in relation to social partners concluding collective agreements. Member States have primary responsibility for complying with the EU Treaties, the EEA Agreement and the European 
Convention on Human Rights. This calls for some kind of legislative framework when Directives are to be implemented. Consequently, the ongoing implementation of EU and EEA law undoubtedly shifts the balance between legislation and collective agreements in favour of legislation.

The impact of EU and EEA law has not resulted in any basic changes to the division of work between the social partners and the legislature in the Nordic countries. The reasons why the changes have not been more profound are probably found in two aspects:

Firstly, Member States have transferred limited regulatory labour-law authority to the EU. In reality, it is not possible for the EU to adopt Directives concerning a number of working conditions which are sensitive to labour-market parties, including the right to unionise and take industrial action, as well as wage conditions, protection against termination and social schemes, such as labour-market pension schemes.

Secondly, the social partners and the legislature in all Nordic countries seem to have agreed to implement EU and EEA law obligations in such a way as to minimise clashes with the existing national division of work. Generally speaking, the EU and EEA law obligations appear to have been implemented to such a neutral extent that the Directives have not paved the way for further legislation regarding the working conditions concerned.

Labour-law Directives have led to more employment-law legislation in all Nordic countries, but not to systematic legislation on wages and working conditions. Legislation in particular has been given a more prominent role in Denmark, Iceland and Sweden, while in Finland and Norway the Directives have largely been integrated into the Work Agreement Act and the Working Environment Act, which already regulated a broad range of working conditions.

A number of Directives have been difficult to handle in the national implementation process. This applies, for example, to the Temporary Workers Directive from 2008, which gave rise to major problems in most of the countries. In Denmark, the social partners had to abandon implementation of the Directive, and it only became possible to adopt an implementation Act of Parliament after the Commission had taken steps to take legal action against the Danish state before the European Court of Justice. In Sweden, too, it was difficult to implement the Directive, also because the Directive focuses on putting temporary workers on an equal 
basis with the own employees of changing user enterprises, while the Swedish model focuses more on establishing a regular relationship between the agency and the temporary worker. In Finland and Norway, there has been a political discussion about whether the Temporary Workers Directive prevents existing restrictions on the use of temporary workers. The Finnish implementation has been challenged by an employer for not bringing an end to unjustified, collective-agreement-regulated restrictions on temporary work, and the Finnish court has submitted a number of questions to the European Court of Justice on the interpretation of the Temporary Workers Directive (C-533/13). In January 2015, the EFTA Surveillance Authority asked the Norwegian government to explain and justify the restrictions on the use of temporary workers which still exist in the Working Environment Act and collective agreements.

Labour-law Directives have largely not been aimed at harmonising collective agreement systems per se, as the only Directives adopted concern the information and consultation of wage-earners. Conversely, striking developments have taken place within the framework of the Council of Europe. This is not because the political bodies have adopted new rules on the freedom to conclude collective agreements and to take industrial action, but because in recent years the European Court of Human Rights has entertained an increasingly dynamic interpretation of the existing provision on freedom of assembly in Article 11 of the Convention on Human Rights, which gives wage-earners the right to establish and join trade unions "in order to protect their interests." In this development, the rights to negotiate a collective agreement and take industrial action have today become pan-European human rights, and it is now possible, for example, to have the frequent government intervention in industrial action on the Danish and Norwegian labour markets legally reviewed by national courts and the Court of Human Rights.

There is no doubt that the item which has given rise to the greatest political discussion across the Nordic countries in recent years is the Posting of Workers Directive. This is a complicated area with a number of intersecting considerations, so it is difficult to reach a broad consensus across the social partners and the political parties. It is striking that the national implementations of the Posting of Workers Directive in all the Nordic countries have been challenged by either the EU Commission and the EF- 
TA Surveillance Authority or by decisions from the European Court of Justice or the EFTA Court as part of prejudicial submissions from national courts. The judgment of greatest principal and practical significance is undoubtedly the Laval judgment. In both Denmark and Sweden, it led to a principally new structure in the form of a statutory framework for the exercise of industrial action rights towards service providers from other EU countries. In Denmark, the social partners chose to design a joint solution themselves, whereas this was not possible in Sweden. The Swedish solution is still controversial and, following complaints from the LO and the TCO, it has been criticised by both the ILO and the Council of Europe for infringing on the right to take industrial action.

\subsubsection{Changed role of courts in the labour-law system}

One of the most striking features of the European impact on Nordic labour-law systems is the fact that the courts have gained a more prominent role in relation to the social partners and the legislature. The courts have gained more of a law-making function resulting from their duty to interpret the conformity of national rules with the EU, EEA and ECHR. At the same time, they have gained a more rights-verifying role arising from their duty to check whether a challenged legal position is compatible with obligations under EU, EEA and ECHR law.

The more prominent role of the courts will restrict the wide (political) latitude which the legislature and social partners have normally had in the labour-law systems of the Nordic countries. Both the national and the European courts have already addressed a large number of questions which, in a Nordic tradition, have largely been considered to be purely political issues. This applies, for example, to the question of whether government intervention in industrial action is an unjustified intervention into the freedom of association; whether industrial action is compatible with the right to the free exchange of services; and whether a statutory age limit for automatic cessation of employment constitutes age discrimination. In all three cases, the political estimate exercised by the legislator is subject to judicial review on the basis of general, vaguely formulated European principles of law. 
The more prominent role of the courts is not only significant in terms of the political sphere of action, but also for the possibilities of wageearners and employers, when it comes to acting on the basis of trust in applicable national law. The national law rules and collective agreement rules must as far as possible be interpreted in accordance with European obligations. The interpretation made by the Nordic courts must thus as far as possible reflect the dynamic development of the law which is carried out by the European courts. If it is not possible to interpret national law in conformity with EU law, the courts may be obliged to give EU law precedence over national law. If an EU rule has direct effect (precedence), this may mean that private individuals are left with the risk of a national legal position which infringes on EU law.

One striking example is Sweden's trade unions, when the Industrial Court held against them and ordered them to pay compensation to the Latvian enterprise, Laval, for having taken industrial action which was lawful under Swedish law, but - as it turned out - in contravention of Treaty-based EU law principles of the free exchange of services. The striking point is that the majority of the judges on the Industrial Court did not seem to have any real doubts when it came to ordering private associations to pay compensation for a behaviour which was in accordance with Swedish legislation.

Another striking example is Danish companies which have been ordered by the court to pay compensation for terminating employees, where such termination was made in accordance with the Salaried Employees Act, but not in line with the EU principle of equal treatment, which prohibits discrimination on account of age, disability, etc. Until now, the Supreme Court has stated that it is not possible to interpret one of the rules in the Salaried Employees Act in accordance with EU law and has furthermore submitted questions to the European Court of Justice on balancing the EU principle of equal treatment with the principle of legal certainty. The Supreme Court thus seems to indicate that the European Court of Justice should attach more importance to the principle of legal certainty and the principle of the protection of legitimate expectations in its case law.

The national courts find themselves in a special dilemma in cases where the European courts (perhaps) take a different view of the same legal questions. This was the dilemma in which the Norwegian Supreme 
Court found itself when deciding whether a generally applicable collective agreement was compatible with the Posting of Workers Directive and Article 36 of the EEA Agreement. The Supreme Court was not convinced that the EFTA Court was right in stating that a number of wage-related elements were to be assessed not only in accordance with Article 3(1) of the Posting of Workers Directive, but also in accordance with Article 36 of the EEA Agreement on the free exchange of services. The reason the Supreme Court was hesitant about the opinion stated in the EFTA Court judgment of 23/1/2012 in E-2/11 (STX) was not only that the Supreme Court itself had a different understanding of EEA law, but also that it found its own understanding to be in accordance with the case law of the European Court of Justice. With its judgment, the Supreme Court landed in an open conflict with the EFTA Court; however, the Supreme Court's understanding of EEA law seems to be in line with the understanding (subsequently) expressed by the European Court of Justice in its judgment of 12/2/2015 in C-396/13 (Elektrobudowa) in the case concerning the Finnish collective agreements which had been made generally applicable.

The Danish and the Norwegian Supreme Court have addressed the shared challenge which arises in situations where national courts are not convinced of the correctness of decisions made by European courts. The Norwegian Supreme Court chose the slightly daring approach of openly disagreeing with the understanding presented by the EFTA Court, while the Danish Supreme Court chose a more cautious approach by submitting - formally neutral, but actually critical - questions to the European Court of Justice regarding its case law. Regardless of these differences in approaches, these two decisions would seem to indicate that the Supreme Courts expect to be able to have an open, critical dialogue with the European courts on important principal questions. 


\subsection{Bibliography}

Ahlberg, K. \& Bruun, N. (1996) Kollektivavtal i EU. Om allmängiltiga avtal och social dumping. Juristförlaget, Stockholm.

Ahlberg, K. \& Bruun, N. (2010). Upphandling och arbete i EU. Svenska institutet för europapolitiska studier, Stockholm (Sieps 2010:3).

Andersen, S. K. (2003). EU og det nordiske spil om lov og aftale. The National Institute for Working Life in Sweden, Stockholm (SALTSA Report 2:2003).

Andersen, S. K., Dølvik, J. E. \& Ibsen, C. L. (2014). De nordiske aftalemodeller i åbne markeder - udfordringer og perspektiver. Fafo, Oslo (Fafo report 2014.08).

Bruun, N. et al. (1990). Den nordiska modellen. Liber, Lund.

Bruun, N. et al. (1992). The Nordic Labour Relations Model. Darmouth, Aldershot.

Bruun, N. \& Malmberg, J. (2005). Finska og svenska domstolar som arbetsrättsliga gemenskapsdomstolar. In: Nyström, N., Liber Amicorum Reinhold Fahlbeck, Juristförlaget, Lund, pp. 65-90.

Bruun, N. and Malmberg, J. (2005). Arbetsrätten i Sverige och Finland efter EUinträdet. In: Kerstin Ahlberg (ed.), Tio år med EU - effekter på arbetsrätt, partsrelationer, arbetsmarknad och social trygghet. Arbetslivsinstituttet, Stockholm, pp. 7.

Dølvik, J. E. (2005). De nordiske arbeidslivspartene i EU: Europeisering, påvirkning og forsvar av de nasjonale avtaleregimene, in Ahlberg K. (ed.), Tio år med EU effekter på arbetsrätt, partsrelationer, arbetsmarknad och social trygghet, Arbetslivsinstituttet, Stockholm, pp. 51.

Eldring, L. \& Alsos, K. (2014). European Minimum Wage: A Nordic Outlook - an update. Fafo, Oslo (Fafo-paper 2014:21).

Evju, S. (2010). Kollektiv autonomi, "den nordiske modell”, og dens fremtid. Arbeidsrett, Volume VII, pp. 1-29.

Evju, S. (red.). (2013). Cross-Border Services, Posting of Workers and Multilevel Governance, Institutt for privatrett. Oslo 2013 (Skriftserie 193).

Evju, S. (red.). (2014). Regulating Transnational Labour in Europe: The quandries of multilevel governance. Institutt for privatrett, Oslo 2014 (Skriftserie 196).

Kristiansen, J. (2013). Aftalemodellen og dens europæiske udfordringer. Jurist- og Økonomforbundets forlag, København.

Källström, K. \& Sigemann, T. (1990). Komparativ nordisk arbetsrätt i huvuddrag. Nordisk Ministerråd, København (NORD 1990:93).

Malmberg, J. (ed.). (2000). Laglönekonkurrens och arbetstagares integritet. Arbetslivsinstituttet, Stockholm (Arbetsliv i omvandling 2000:2).

Malmberg, J. \& Sigemann, T. (2008). Industrial actions and EU economic freedoms: The autonomous collective bargaining model curtailed by the European Court of Justice. Common Market Law Review, pp. 1115-46.

Malmberg; J. (2011): Arbetsrätten efter EU-inträdet. Svensk Juristtidning, pp. 430-39. Nergaard, K. (2010). Fagorganisering i Norden, Status og utviklingstrekk. Fafo, Oslo. (Fafo-report 2010:25). 
Nielsen, R. (2002). Europeanization of Nordic Labour Law. Scandinavian Studies in Law, Volume 43, pp. 37-75.

Nielsen, R. (2013). EU labour law (2nd edition). Jurist- og Økonomforbundets Forlag, København 2013.

Nyström, B. (2010). The internal market and the future of labour law in Europe: Insights from the Nordic countries. European Labour Law Journal, pp. 7-18.

EU och arbetsrätten (2011). Nordstedts Juridik (4th edition). Stockholm.

Sigemann, T. et al. (1990). Arbetsrätten i Norden. Nordisk Ministerråd, København (NORD 1990:42).

Stokke, T. Aa. (2010). Allmenngjøring i EU og Norge. Fafo, Oslo (Fafo-report 2010:14).

Wahlgren, P. (ed.). (2002). Stability and change in Nordic labour law. Scandinavian Studies in law, Volume 43. 
Part 2 



\section{Altered Labour Market after Vaxholm}

Hans Tilly ${ }^{2}$

\subsection{Introduction}

I was sitting at home one evening, reading the newspapers and magazines I had brought home with me in my briefcase. One of them was a newspaper called Nyliberalen (The Neo-Liberal). There I saw an article about Byggnads (The Swedish Building Workers' Union) with a picture of our logo - a logo which shows a person wearing a hardhat in profile. What I saw was something that would make any calm man's blood boil. What they had done was to put a Nazi SS symbol on our logo. It was just one of many attacks from debaters and journalists, mostly in right-wing newspapers.

Dagens Nyheter or "DN" (the biggest daily morning newspaper in Sweden) was the worst example with the journalist Marcej Zaremba at the forefront taking it upon himself to smear Byggnads. One example was a series of articles in which he included a photograph of a banner, or a table flag, that we often have in the trade-union movement. The photograph had been manipulated so instead of "Workers in all countries unite", the flag bore the slogan "Workers in all countries stay put". Peter Wolodarski (editor of DN) wrote in an editorial "Let us hope that Byggnads' shameless stance never becomes that of Sweden."

The Young Conservatives in Sweden (MUF) email-bombed me on a daily basis for a period of time, and on their website my face was superim-

\footnotetext{
2 President of Byggnads, the Swedish Building Workers' Union, 2002-2012.
} 
posed on the body of Don Corleone (the Godfather) with the caption "Two peas in a pod". One day, a package arrived at work containing a horse's head, i.e. the same type of warning that the mafia sends to its enemies. Thankfully, it was only the cut off head of a rocking horse bought in a toyshop. But just think of how much trouble they went to at the Young Conservatives. I have saved the horse's head and often produce it when I speak about Laval and Vaxholm. I actually see it as a rather creative humorous whim of an opponent during this period of time, and the list of attacks and caricatures is as long as your arm.

This was how things were right in the midst of the events that started in the summer of 2004, which eventually evolved into a long chapter in the history of Sweden's labour movement: the Vaxholm Conflict, an issue that impacted all of Europe and led to a political conflict between Sweden and Latvia.

What type of labour market would it lead to in the future? What can we expect regarding our strong collective agreements? Was there support for the Swedish model or was it all a game exploited by forces wanting to change the balance of power on the labour market?

In the following, I describe some of the events that have been affecting the labour market for a number of years. It by no means covers everything, but I include a number of examples from everyday life.

\subsection{The LO (Swedish Trade Union Confederation) and the Social Democrats}

When the Vaxholm issue arose, it was no bolt from the blue. For years, Byggnads had been involved in different conflicts with rogue employers, such as Polenkonsulten (a company calling itself the Polish Consultant), which set up operations in Skåne in 2002. They inserted bold newspaper ads advertising cheap labour paid well below the levels in collective agreements. So low in fact that it was easy to understand that it would be impossible for them to pay taxes and social security contributions for companies and workers.

Another notable case was when 92 Slovakian furnace masons went to install new furnaces at SSAB in Luleå in the summer of 2003. As usual, the 
Byggnads section was quickly ready to conclude a collective agreement and agree a wage which was in line with normal wages in the region. An agreement was concluded and an hourly wage was set at SEK 137 per hour.

During their work, there was a tragic accident and one of the masons died. Afterwards the company in question tried to cover it up, but the accident was so serious that it was difficult to cover up and the section eventually heard about it. When the section looked into the situation at the workplace, it emerged that the workers had been working under awful conditions. There was a total lack of personal protection gear, e.g., face masks to protect the workers from asbestos in the furnaces to enable them to take the heat. Gloves were another example: when this type of work is being done, the bricks are still hot. In both cases the Slovakian masons retrieved the used masks and gloves of their Swedish colleagues from the bin.

After looking into the actual wages of the masons, it emerged that they had been paid SEK 13-18 per hour. They had signed that agreement on the bus trip from Slovakia to Luleå. They knew nothing about the wage agreement that Byggnads had concluded with the company. The masons were ultimately paid SEK 149 per hour after successful negotiations by Byggnads.

At this time, I started working hard to bring up the issue with politicians and LO colleagues. I particularly remember a conversation I had with Göran Persson, who was Prime Minister at the time. I told him about what was about to happen in the construction labour market with regard to rogue employers. Göran Persson was angered by what I told him and felt that it was important to continue safeguarding collective agreements.

During the autumn of 2003, Berit Rollén led an Inquiry into the enlargement of the EU. She wrote in her report that there should be a requirement stipulating the number of hours worked per week to be able to receive Swedish social benefits. In a comment to this, Göran Persson said: "We want free movement but not social tourism." Naturally, this was a rather unfortunate statement for which he received many comments and which I believe made him shy away from supporting our campaign more strongly. This was unfortunate, because I think that we would have otherwise been in a much stronger position to counter all the false accusations we received. As regards other Social Democratic politicians, support 
was strong, particularly from politicians with links to the LO. But there were also those who regarded us with scepticism.

It was important to gain support from the big trade unions that had not been dragged into similar conflicts; IF Metall and the Municipal Workers' Union were good examples. I was invited to different trade unions on several occasions to tell them about our work and talk about how we could work together on this issue. A couple of years later, more and more were affected by the "new labour market". A new actor, Farmartjänst, had set up operations in the collective-agreement area of the Municipal Workers' Union offering services in agriculture. In 2005, Byggnads and the Municipal Workers' Union started a joint project in Skåne with the aim of monitoring the labour market.

\subsection{The position of different parties}

There was a great deal of support for us in the Social Democratic Party and many were very supportive and encouraging when I met with them during my visits to Riksdag (the Swedish Parliament) or at party meetings. It was also at these meetings that I gained an inkling of other politicians' views and position on this matter, both those from my own party, but mostly from other parties.

Certain people were interested in airing their views on our actions in the media or newspaper articles. There were those who wanted people to believe that high construction costs were caused by Byggnads' collective agreements. We had national agreements with local wage negotiations which meant that the construction workers received good wages. I often had to explain that wage costs represented about $17 \%$ of total construction costs. But foreign construction workers working for lower wages and under worse conditions believed in those that criticised us and thought that construction costs would decrease.

Fredrik Federley, Chairman of the Centre Party's youth organisation, asked: "Why does Tilly believe it's ok to buy a T-shirt that has been produced cheaply, while a flat has to be expensive?" Fredrik Reinfeldt, Chairman of the Moderate Party, claimed that "Byggnads is a disgrace to the whole of the LO." Moreover, he said that construction workers earned too 
much. The worst were the MUF, who, apart from the horse's head they sent me, constantly compared our actions to those of the mafia. The MUF were actively writing articles in local newspapers all over Sweden saying that we had a nasty view of humanity and encouraged construction workers not to join the union.

The Moderate Party's Party Secretary, Sven Otto Littorin, wrote on their website that he supported the MUF when they compared us to the mafia and had sent me a horse's head. Littorin later became the Minister for Employment and helped to undermine the ability of trade unions to monitor the labour market.

One of those who repeatedly expressed himself aggressively was Carl B Hamilton, MP for the Liberal Party. He must really hate trade unions in general and Byggnads in particular, as he said the following about wages: "Swedish wages and jobs must be secured partly through new conditions," i.e. lower wages and deteriorating working conditions for ordinary wageearners. It is impossible to interpret what he meant in any other way.

On 17th December 2004, the Riksdag held a special debate on collective agreements. The debate had been requested by Anders Karlsson, a Social Democrat MP and member of Byggnads. During the debate, the Left Party and the Green Party supported safeguarding collective agreements and the Swedish model. In right-wing newspapers, politicians and opponents were given a great deal of space to express their views on Byggnads' actions as being nationalistic.

It was difficult to get newspapers to accept articles in response to unsubstantiated accusations, mostly in editorials. I won one victory over DN and Peter Wolodarski who had refused to accept a rejoinder from me. The news ombudsman at DN criticised the newspaper for refusing to publish my rejoinder. This resulted in big headlines and gave more readers, since parts of the rejoinder were reproduced in the paper.

During this time I did get the opportunity to meet many of our detractors, including Peter Wolodarski, who is now editor-in-chief of DN. At the time an aggressive opponent, today I sense that he understands that we actually supported the equal value of all human beings.

I absorbed all the support I was given like a sponge because it reinforced my self-confidence when I ended up in different discussions. Support from the white-collar workers' unions HTF and SKTF was valuable, 
for example. But the best was the honorary award I received from Artister mot nazister (a foundation of artists against Nazism) for the drawing up of a policy on and training elected representatives with the aim of stopping racism and right-wing extremist groups. Prominent in this were two great musicians, Mikael Weihe and Tomas Ledin. We were often accused of being xenophobic when we were actually working for equal conditions for everyone in the Swedish labour market, which is why the honorary award felt particularly good.

To top it all off, the later world-renowned author Stieg Larsson (cofounder of the non-profit foundation EXPO which monitors right-wing groups and xenophobia in Sweden) was the one who wrote our policy. My work on these issues later led to my having the honour of becoming a member of the board of EXPO.

\subsection{Employer reactions}

Employers spoke with forked tongues. Every time I met the CEO of Sveriges Byggindustrier, BI (The Swedish Construction Federation), I brought up the issue about who was bankrolling and pressing the issue against us in Vaxholm. He responded by saying that they supported the Swedish model and did not know who was paying for Laval's two lawyers. I also asked whether we could write a joint article, since they actually claimed to support the Swedish model with collective agreements. This would also be a clear signal to all the small companies which were members of the employer organisation and who risked becoming competed out of existence by the companies which did not comply with our laws and rules. The answer was always the same: they did not want to get involved at this time.

It was eventually revealed that the Confederation of Swedish Enterprise was paying Laval's legal fees. They must have known this at the Construction Federation, since their CEO is always a member of the executive committee of the Confederation of Swedish Enterprise.

Certain employer organisations were more aggressive than others and organised seminars about the contents of collective agreements, but at the same time took the opportunity to question Swedish labour law in its entirety. My priority was to participate in everything I was invited to. This 
gave me the opportunity to put our views across and repudiate the worst of the false accusations and myths about Byggnads.

On one occasion, I sat listening as a member of the audience at a seminar to the moderator spewing bile about Byggnads and incorrectly describing how we had acted and what we had demanded during our negotiations with Laval. In the break, I angrily went up to the moderator and told him that either he was not sufficiently knowledgeable about the issue to be able to make a comment or he was giving a false picture of what had happened on purpose. His comment: "I didn't know you were here."

These examples illustrate how important it was for us to be active at all levels. At the same time we saw that the market was starting to change. Many purchasers and rogue companies took this as a pretext to evade both agreements and laws.

\subsection{Support from small companies}

If wage-dumping is allowed, small Swedish companies are forced to cheat to survive in the rogue competition. I was surprised that the employer organisations did not discuss this issue. Their conclusion was that the collective agreements should be revamped or completely scrapped.

On the website of the Confederation of Swedish Enterprise you could read: "Foreign companies should be under no obligation to pay average Swedish wage levels." Many small businesses called or contacted me during this period and described how they were losing calls for tenders because it was becoming more acceptable to employ illicit workers, which of course happened when foreign companies took on assignments for SEK 100-150 per hour. Every time I asked whether we should join forces and write an article or similar, they would decline because they said they could lose contracts if they did.

In one survey, eight out of ten said that Swedish collective agreements should apply to foreign workers working in Sweden. Seven out of ten said that we had the right to take industrial action to ensure that the agreements apply.

Several years later, in 2010, I co-authored an article with Mats Paulsson, $\mathrm{CEO}$ of PEAB, about the constantly deteriorating conditions. The arti- 
cle was primarily based on the Act on Public Procurement. We brought up issues like taxes and social security contributions being withheld, working hours far longer than permitted and that a change in the approach to health and safety meant that the route we had taken towards a better working environment risked becoming a race to the bottom instead.

That article proved to be a great success for me, whereas Mats Paulsson was heavily criticised by his employer organisation. "I stand by what I wrote," Mats told me. For that alone he should be greatly applauded.

\subsection{Europe, the trade union and Riksdagen}

As President of our Nordic federation, the NFBWW, it was important to provide information about what had happened and to obtain support for our trade union demands which, after all, concerned our right to conclude agreements.

We received strong support initially but it became more irresolute because the situation was different in our neighbouring countries. The situation for the Danish union organising construction workers was very similar to ours in Sweden. We pressed the issue jointly too, not least vis-à-vis our European federation, the EFBWW, during the first few years. The Danes subsequently chose to resolve the issue between the social partners and thus were against a solution which did not involve the Lisbon Treaty.

In the EFBWW, I perceived that several countries were uncertain about the issues that were linked to the Laval case. I think this was due to the fact that our agreements and our organisations in the Nordic Area play a much stronger role and exert greater influence than the trade unions in many other European countries.

There was one issue where we had completely opposite views: minimum wages with state interference. We were completely against this, while the rest of Europe, except for the Nordic countries, believed this to be a good solution and that it would resolve some of the problems the unions encountered when they tried to raise wages and the level of affiliation.

The severity of the problem with regard to rogue companies or exploited workers largely depended on the construction cycle in the different countries. At this time, various trade unions started many projects in 
the Nordic Area and Germany with the aim of providing information about wages and working conditions, but also trying to encourage workers to join a trade union.

\subsection{Altered labour market}

There was much toing and froing, and lots of water can flow under the bridge in just a few years. Conflicts arose in many parts of Sweden, not least concerning major infrastructure projects. One of these was the major tunnel project in Malmö. This was a construction project that ran for three years at an estimated cost of SEK 10 billion. Workers from Poland were the dominant group of employees doing the heavy dirty work. There might have been 60 construction workers or perhaps 100, but it is difficult to say without full transparency. They were employed by the Irish company Rimec and were registered as living in Ireland, often as many as 40-odd workers at the same address according to information obtained by journalists visiting the workplace. They were recruited in Poland, flown to London to sign documents and then transported on to Sweden. In this way they belonged to the UK, which made it possible to lower their social security contributions from $32 \%$ to $10 \%$. This also meant that millions of tax revenues were withheld.

The workers' wages were in line with the agreements, but they worked 220-260 hours a month instead of 178 , which is the norm. In addition, they worked underground, which, according to the collective agreement, meant that they should have worked fewer hours per week or month.

Joining the union entailed a huge risk for these workers, as it could have led to their immediate dismissal. This meant that almost no one chose to become a member. And it meant that our sections had huge problems trying to follow up on what were the prevailing wages and other conditions at the company.

An example of how difficult it is to follow up collective agreements, working-time laws, and OHS laws is a case brought before the Swedish Labour Court. The lawsuit concerned the Irish company Rimec regarding work carried out over a long period of time. Byggnads had been involved in both local and central negotiations without result. When the case was 
brought before the Labour Court, the employer organisation notified the Court that Byggnads had been negotiating with the wrong party. Byggnads had been negotiating with Rimec Ltd instead of Rimec Group where the workers were employed by a subsidiary, Rimec Construction. This was a deliberate way to make it difficult for the trade union to follow up on a breach of agreement.

\subsubsection{The Laval Act}

The government decided to appoint a commission of inquiry aimed at assessing possible amendments to Swedish legislation required by the ruling of the European Court of Justice. The different interpretations of the Directive and proposals put forward by the Inquiry are not discussed here, as they are described in other documents.

The Inquiry dealt with whether a Swedish trade union could demand that an agreement be concluded if there is already an agreement in force in the home country of the company employing the posted workers. In short, the company should know about the minimum wages that can be paid to posted workers. Byggnads' agreements were criticised because wage negotiations are only conducted after an agreement has been concluded.

The conditions required by a collective agreement should be clear and predictable for employers employing posted workers in Sweden. In order to help foreign companies find information about the rules that apply, a liaison office was set up. The Swedish Work Environment Authority was given the task of running this liaison office. After several rounds of referrals and certain adjustments, the Swedish Parliament (Riksdag) made its decision and the Act entered into force on 15th April 2010.

The Act was criticised from several directions, by trade unions and employers alike. The Confederation of Swedish Enterprise was in favour of a ban on supplanting foreign collective agreements. Byggnads claimed that it was easy for the employer to provide false wage information, which was difficult to check since the workers were threatened with dismissal if they revealed their real wages. Byggnads claimed that the burden of proof lay with the union as to whether the wrong wages were paid. There is an ongoing discussion regarding the need to amend the Act, and it was discussed during the national election campaign in 2014. 


\subsubsection{Importance of the role of the Labour Court and the European Court of Justice}

In my view, the decision made by the Labour Court in the Laval case is questionable from start to finish. In December 2004, the Court ruled that the conflict was legal and did not need to be stopped. The decision meant that Laval was unable to invoke an embargo on strikes and lockouts by referring to the EU Treaty concerning the discrimination of foreign employers

In March 2005, the main hearing was held on the Laval case in the Labour Court. The Court based its ruling on the wage demands that in the negotiations Byggnads had put forward the demand that a Swedish collective agreement should supplant a foreign agreement.

Public pressure was great regarding what was right and wrong in this issue. The Labour Court relented and decided that it could not make a decision until the Court of Justice had issued its preliminary ruling. The Labour Court decided to stay the proceedings. This is where I believe the Labour Court caved to media pressure mostly from the right-wing press. Moreover, I find it incomprehensible that the Labour Court ordered Byggnads and the Electricians' Union to pay huge damages five years later.

Reactions to the Court of Justice's treatment and preparatory work with statements issued by different people went from hope to disappointment. The opinion of Paolo Mengozzi, Italy, in the spring of 2007 was positive for us and gave us hope that we would win in the Court of Justice. Six months later the Court issued its ruling. It was a loss for Byggnads, trade unions, the Swedish model and the workers who come to Sweden to work.

\subsection{What could we have done differently?}

This is the question many of us have asked ourselves over the years and, naturally we have occasionally had internal discussions about it. We should have been clearer regarding the fact that concluding an agreement was one aspect of the process and did not take place at the same time as wage negotiations. Contact with purchasers, in this case the municipality of Vaxholm, could have clarified the municipality's requirements imposed on companies with regard to construction assignments. One requirement of Vaxholm municipality was that companies must have a collective agreement. One route 
could have been for the question to have been transferred to the central level to start discussions before it became such a huge issue where neither party was able to back down from their demands.

The question is naturally whether the conflict would have occurred sooner or later as, in my view, there were strong forces wishing to press this issue.

One important aspect was that we felt secure in our agreements and that it was natural for us to conclude collective agreements. Certainly, there were companies which refused but, after discussions and threats of blockades, order was restored. Normally, employees supported us and knew the importance of an agreement, as it provided them with a sense of security and insurance if a company were to go bankrupt. In the construction sector it happens all too often that companies do go bankrupt, and normally small newly started companies were not in favour of concluding an agreement.

The main problem with the workers at foreign companies was that they were scared of the unions in two ways: firstly, due to a total lack of trust in unions in their home countries and the view that a union is an extension of the authorities and, as such, is corrupt; secondly, because they had been threatened that joining or making any contact with a union would lead to immediate dismissal and being sent home straight away.

Unfortunately we have met many threatened workers over the years. Therefore we developed and intensified the information we provided to foreign labour by organising big meetings or individual contacts to explain who the unions work for.

Byggnads employed its own interpreters to cope with the language barrier. This helped enormously and trust increased. Many got in touch with our sections when problems arose such as unpaid wages, etc. Naturally, this was something we should have started doing earlier, but hindsight is always $20-20$. 


\subsection{What is the current situation?}

Public opinion swung and people started to sympathise with our demands regarding collective agreements and having a labour market in good order when the plight of berry pickers and tree planters in the forestry sector was revealed in several TV programmes. Workers had been conned into coming to Sweden with the promise of being able to earn a great deal of money. Many had sold property or borrowed money to travel to Sweden. When their wages were not paid and there was no money left to pay for the journey home, the general public saw how heartless certain employers could be.

There are many foreign companies and workers today: in major infrastructure projects, the private housing market and also in companies recruiting a lot of foreign labour. To a large extent they work under conditions that correspond with the agreements that have been concluded between the social partners.

It is difficult to get an overview of the private housing market now that Byggnads has stopped monitoring it. The general view, however, is that there are problems with occupational health and safety and some illicit workers, even if the tax deduction scheme ROT (for repairs, conversions, extensions) has done away with some of that problem. Health and safety issues are still important for the whole sector and particularly for foreign workers who do not dare demand a safe working environment.

It is satisfying to note that the view on how the labour market should be organised has shifted for the better. The most positive aspect is that no one asserts that unions are xenophobic or racist. But there are still problems that need to be resolved so that workers are not exploited. You have to work proactively and keep one step ahead of all the rogue employers who constantly find new ways of evading rules, agreements and laws.

\subsubsection{Has this had an impact on the relationship between the social partners?}

No, I do not think it has. As I have written before, different events in the labour market changed the views of many Swedes, for example, when it emerged in the media how Thai berry pickers and African tree planters 
were treated. At different seminars that I participated in together with the CEO of the Construction Federation after the Laval ruling, we agreed on how important it is to have conditions that are in accordance with collective agreements, even though we did not agree on what the collective agreements should regulate.

\subsubsection{New report}

The question of labour immigration linked to the events in Vaxholm lives on. On 27th January 2015, a new report by Fredrik Segerfeldt was published by Migro, a liberal public opinion institute. The report was titled "The LO is crying wolf - trade union scaremongering about migration after EU enlargement".

Despite the fact that ten years have passed, the report attacks unions. The report includes many of the statements that have been made on the issue and several of them are taken out of context, which, in my view, is a way for the author to bias the report as he wishes and not to the advantage of the unions.

The report says nothing about what it was actually all about: everyone's right to equal conditions regardless of whether they come from Latvia or Linköping. Segerfeldt only describes examples of workers who have worked under conditions akin to the collective agreement in the sector. On the other hand, there is no mention of the awful examples from Lulea and SSAB, Thai berry pickers or African forestry workers cited here.

I am convinced that the crux of the matter is the very scope of the collective agreements. Many who believe in collective agreements would like them to be wafer thin and do not wish to regulate issues in detail. This would unfortunately open up to interpretation, which would primarily benefit employers. 


\section{Laval, the Swedish System of Collective Bargaining and Professionals}

Lena Maier Söderberg ${ }^{3}$

\subsection{Introduction}

The autonomy of the social partners and the impact of EU law on the national systems of collective bargaining and national wage formation became the focus of the whole of Europe when the European Court of Justice (ECJ) notified its judgment in the Laval case in December 2007 (C-341/05 Laval, ECLI:EU:C:2007:809). The case was about the collective-agreement demands that can be made for workers temporarily posted by their employer to another Member State outside their home country. It concentrated primarily on the interpretation of the Posting of Workers Directive (Directive 96/71/EC concerning the posting of workers in the framework of the provision of services), but also the provisions in the Treaty on the free movement of services.

Reams have been written about the Vaxholm conflict and the Laval case. Few legal rulings have been highlighted from as many angles. At the same time, ten years on, we still see the repercussions of the conflict. At the time of writing, there are two public Commissions of Inquiry reviewing the Swedish Posting of Workers Act and Lex Laval, which were adopted in order to adjust to the ECJ judgment in the Laval case.

${ }^{3}$ Chief Legal Advisor at Saco, the Swedish Confederation of Professional Associations. 
Despite the fact that the conflict only concerned a limited segment of the Swedish labour market, it struck the very heart of the Swedish collective bargaining model and its values. The ECJ judgment in the Laval case has also upset the balance between the social and the economic dimensions in the EU, where freedom of movement takes precedence again over fundamental trade-union rights.

My contribution is to highlight Laval from the perspective of Saco (the Swedish Confederation of Professional Associations), and professionals, i.e. university graduates and professionals with a college degree. As this is my perspective, I will not bring up all the issues dealing with Laval and the Swedish system of collective bargaining. Instead, I will concentrate on some of the issues and problems that were specific to Saco and university graduates and professionals at the time of the Laval judgment.

\subsection{Does the Laval judgment really have an impact on Saco and professionals?}

Since the notification of the Laval judgment by the European Court of Justice and when the Commission of Inquiry (SOU 2008:123 Proposed measures further to the Laval judgment) subsequently started its work, Saco has often been asked whether this really has any impact on Saco, its member associations and their members.

Laval is about the free movement of services and posted workers, in other words, a limited part of the labour market. Until now it has been basically true that the members of the Saco associations, all of whom are university graduates and professionals with a college degree, have not been affected to any large extent. Even though we now see that posted workers are becoming increasingly common in certain sectors where the members of the Saco associations operate, for example, within IT. Since Sweden became a member of the EU, Saco has embraced the freedom of movement which creates new possibilities for university graduates who wish to work in Europe. Similarly, Saco has welcomed workers and companies to Sweden.

Before the Laval judgment was issued, however, it was self-evident for Saco that a system of collective bargaining like Sweden's must be respect- 
ed, in the same way that other national labour-market models must be allowed to exist in the EU. We believed that with the diversity which prevails throughout the $\mathrm{EU}$, it would be difficult to achieve total predictability regarding employment and working conditions that should be applied to posted workers. Nor is it entirely easy for a foreign company not wellversed in Swedish law to understand the legislation that must be complied with, such as in the area of health and safety. Within the framework of systems with a general applicability of collective agreements, as in Finland and Norway, it is not, moreover, entirely clear how to determine the hard core that shall apply to posted workers.

However, when the Laval judgment was issued, we realised that an adjustment to Laval could have both a direct and indirect impact on the Swedish system of collective bargaining and its values, e.g. the freedom and right to collective bargaining, flexibility, reciprocity and accountable partners. If these values are not safeguarded, there is a risk that the system as such will lose some of its legitimacy.

A further consequence of Laval, which contrasts starkly with the Swedish system of collective bargaining, is the ECJ's strict interpretation of the "hard core". In Sweden, we view collective agreements as a whole: they are a package of conditions where different interests have been weighed against each other. With Laval, it became clear that a trade union could not, in relation to a company posting workers to Sweden, demand collective-agreement conditions outside the hard core. This means that the demands are taken out of their balanced holistic context, which is what a collective agreement constitutes.

It also became clear to us that our groups and collective-agreement areas might be affected in the future. If the legislature decided to put forward and include criteria for the collective agreements that qualify in the context of posted workers, it might have an impact on the possibility to enforce the agreements of the Saco associations. That type of state interference is outlandish for our model.

Hence, Saco claimed from the start that all adjustments to legislation arising from Laval must take all social partners and sectoral agreements into consideration. Since even if we speak about the Swedish collectivebargaining model as comprehensive, it is far from homogenous. In Sweden, we have over 115 central parties, about 55 employer organisations 
and 60 trade unions which conclude a total of around 670 collective agreements on pay and general conditions (Avtalsrörelsen och Lönebildningen 2013/Collective bargaining and wage formation in 2013, p. 21, the Annual Report of the Swedish National Mediation Office). Moreover, it is not uncommon for several parties to conclude collective agreements within the same sector. For example, there may be different agreements for blue-collar workers and white-collar workers. And as regards white-collar workers, there may be collective agreements within one and the same sector concluded by both Saco associations and the TCO (the Confederation of Professional Employees) trade unions.

\subsection{Decentralisation versus centralisation}

The autonomy of the social partners in wage formation is a cornerstone of the Swedish collective-bargaining model. In Sweden, the responsibility for wage formation lies with the social partners, without state interference. This freedom and the right to collective bargaining also include different wage formation models within the framework of the Swedish system of collective bargaining. It is only in Sweden, Denmark and Italy that wage formation is a matter for the social partners alone. The Italian government, however, put forward a proposal for minimum wage legislation in the autumn of 2014.

According to Article 153(5) TFEU, the EU lacks legislative competence in the area of pay, at least when legislative initiatives are taken in the area of social policy. The idea behind this exemption is that wage formation is a national matter. This has, however, not prevented the EU from intruding into the pay area in different ways. The rules in EU law on the freedom of movement operate independently of the legislative competence of the EU. In Laval, the ECJ examined the wage demands that shall and may be issued for posted workers. According to the judgment, it is not possible for a trade union to demand anything other than a minimum wage. Sweden lacks minimum wage legislation so the minimum wage that can be demanded must comply with the collective agreement.

The trend in the Swedish labour market is clearly moving towards increasingly decentralised, individual and differentiated wage determina- 
tion at the same time as the importance of tariff agreements is decreasing. Wages are set at the workplace by taking account of the skills and performance of the employee. The collective agreements that cover the members of the Saco associations all dictate individual wage determination and do not include any minimum wages either.

It is not easy to link the Court of Justice's view on wage setting to individual wage setting. The point of departure is centrally determined minimum wage rates. The ECJ also expressly states that, pursuant to the Directive, a Member State is not entitled to impose conditions on undertakings established in other Member States, in the framework of the transnational provision of services, negotiation at the place of work, on a case-by-case basis, having regard to the qualifications and tasks of the employees, so that the undertakings concerned may ascertain the wages which they are to pay their posted workers (Case C-341/05 Laval un Partneri $\mathrm{p}$ 77). A consequence of this should be that negotiated or individual wage setting is not sufficiently transparent; on the contrary, it constitutes an undue hindrance to the freedom of movement. When the Laval judgment was issued, Saco lamented the paradox that the Internal Market, which is based on free competition, hampers wage setting in a free market based on the freedom and right to collective bargaining.

This problem only becomes a problem in practice if a trade union wishes to conclude a collective agreement that stipulates individual wage setting with a company with posted workers. The freedom and right to collective bargaining should prevail in this situation. Laval does not require the introduction of a minimum-wage rate in collective agreements. If a Saco association wishes to conclude a collective agreement including terms of pay with a company with posted workers in the future, ultimately through industrial action, a minimum wage must be negotiated and determined. Such a minimum-wage rate must subsequently also apply in relation to Swedish employers. 


\subsection{Which model for extending terms and conditions - a fourth way?}

One of the most important issues that the Swedish legislature had to consider after the Laval judgment and which was closely linked to the Swedish collective bargaining model, was which method would be used to set pay and other terms and conditions within the hard core.

The Posting of Workers Directive points at three methods to extend employment and working conditions to posted workers: minimum wage legislation, the universal applicability of collective agreements and collective agreements that apply in general alternatively collective agreements that have been concluded by the most representative partners (Article 3.8 Posting of Workers Directive).

When the Posting of Workers Directive was implemented in Sweden, the legislature chose quite simply to maintain the system of collective bargaining we already had, with autonomous collective agreements that can ultimately be enforced through industrial action (SOU 1998:52 Utstationering av arbetstagare/Posted workers). The transposition has been discussed both in Sweden and the EU (see more in, e.g., Maier, Lena, Utstationering av arbetstagare och det svenska kollektivavtalssystemet/Posted workers and the Swedish system of collective bargaining, Saco, 2005, p. 20). The main question has above all been about whether Sweden has complied with the commitment to guarantee a minimum wage for posted workers because we lack a statutory minimum wage, also considering the fact that we do not have a system for the universal applicability of collective agreements. In addition, many saw that the fact that Sweden chose not to apply any of the methods designated in the Posting of Workers Directive as just a pretext to only apply statutory employment and working conditions to posted workers (see, e.g., COM (2003) 458 final, the Commission Communication on the implementation of Directive 96/71/EC in the Member States). Also the Swedish Labour Court brought up the latter issue in its request for a preliminary ruling to the ECJ (AD beslut/Labour Court Decision 2005 no. 49).

When the question about extending pay and employment conditions in the hard core came to the fore again in conjunction with the adjustment made to the Laval judgment, Saco saw a risk in the legislature in practice 
singling out the collective agreement(s) within a sector which would qualify and whose conditions would apply to posted workers. This would have meant that the legislature intervened in the boundaries between collective-agreement areas that the social partners today determine and, at the same time, would have jeopardised the freedom and right to collective bargaining. In other words, it was important for Saco to safeguard the diversity and well-functioning competitiveness between collective agreements that exist in the Swedish labour market and which are founded on the freedom and right to collective bargaining.

In Saco's view, the main threat to the values of the collectivebargaining system was minimum-wage legislation or the universal applicability of collective agreements. Wage formation in Sweden is a matter purely for the social partners. Minimum-wage legislation would entail clear state interference in wage formation. Moreover, it is difficult to reconcile minimum legislation with wage formation that is individual and differentiated. The wage agreements of the Saco associations do not include any minimum wages at all. A system of universal applicability of collective agreements also entails a deviation from the Swedish system of collective bargaining with autonomous collective agreements. For Saco, the freedom and right to collective bargaining, reciprocity and accountable social partners are cornerstones of the Swedish model. If a collective agreement applies within a certain sector through universal applicability regardless of whether an employer is a party to the agreement or not, these values are jeopardised. In Sweden, there are, moreover, competing trade unions within the same sectors which might create a demarcation problem and the right to collective bargaining would be particularly jeopardised in these instances.

At the time of the Laval Inquiry, there was a relatively strong consensus regarding the fact that minimum-wage legislation and universal applicability were two models that were not compatible with the Swedish collective-bargaining model and that it was therefore not possible to introduce them in Sweden. But the other methods included in Article 3.8 of the Posting of Workers Directive were not, in Saco's view, without their difficulties either.

The first alternative in Article 3.8 is the use of collective agreements that are generally applicable to all similar undertakings in the geograph- 
ical area concerned. This alternative came about to cater for systems of collective bargaining similar to those in Sweden and Denmark. One ambiguous aspect of this model was when a collective agreement is regarded as "generally applicable" and to "all similar undertakings". These necessary conditions suggest a fairly large coverage ratio. The question was whether all Swedish sectoral agreements would qualify, also when there are several collective agreements within one and the same sector. And what applies if several collective agreements within one and the same sector only lead to a high coverage ratio together?

The second alternative in Article 3.8 is the use of collective agreements which have been concluded by the most representative employers' and labour organisations at national level and which apply throughout the national territory. This alternative came about primarily to cater for the Italian system of collective bargaining, but could be applicable in Sweden too. The decisive issue here is how to determine which parties are the most representative and in relation to what: sector, industry, work, whitecollar/blue-collar, profession, etc. This alternative seems to presume that the legislature must stipulate where the boundaries should be drawn between organisations, which is currently an aspect reserved for the social partners themselves.

If not all sectoral agreements qualify for the application of the two alternatives offered by Article 3.8, this would naturally entail an intrusion into the autonomy of the social partners and would upset the balance in the labour market. Apart from these problems, Saco also points at the fact that it was not clear whether an application of the methods described in Article 3.8 presumed a form of extension or whether it would be possible to continue to use our Swedish autonomous collective agreements, which can ultimately be enforced through industrial action.

The Court of Justice, however, clarifies in Laval that the aim of the Posting of Workers Directive is not to harmonise the systems for establishing working and employment conditions in the Member States. On the contrary, at national level, Member States are free to choose a different system to those expressly designated in the Directive (C-341/05 Laval un Partneri $\mathrm{p}$ 68). This room for manoeuvre is limited in that the system may not hinder the supply of services between Member States. 
This means that the ECJ did not really reject the Swedish system of collective bargaining - nor the Swedish transposition of the Posting of Workers Directive. What was rejected in Laval were the collective-agreement demands together with the industrial action that was taken to ensure that the demands were accepted. A highly probable guess is therefore that if the collective agreement demands had been clear and predictable minimum requirements within the framework of the hard core of the Posting of Workers Directive, the Court of Justice would not have found the demands and the industrial action incompatible with EU law (with the exception of Lex Britannia, however, which was rejected because it conflicted with the prohibition of discrimination on the grounds of nationality because it was possible to displace foreign collective agreements).

In conjunction with the Laval Inquiry, Saco recommended as little intervention in the Swedish system of collective bargaining as possible. Against the background of the problems and ambiguities that Saco perceived regarding the choice of method to establish pay and other conditions within the hard core, Saco was in favour of considering a fourth method, which lay outside the Posting of Workers Directive. The point of departure would have been the order that applied before Laval, albeit with the requirements that are included in the EU Treaty's provisions on the free movement of services, which, with the Laval judgment, includes the Posting of Workers Directive. In this situation, the social partners would have to ensure that agreement demands in conjunction with industrial action are compatible with EU law.

Saco saw that this possibility would in many respects lead to as little intervention as possible into the autonomy of the social partners and the balance between competing parties in the labour market. Such a model would place a great deal of responsibility on the social partners and on a trade union wishing to demand that a collective agreement be ultimately concluded through industrial action. Not least the Court of Justice's Laval judgment and the Labour Court's final judgment in the Laval case (AD beslut/Labour Court Decision $2009 \mathrm{nr}$. 89) show that it is difficult for a trade union to predict how the ECJ will interpret EU law in an individual case when industrial action has been taken.

The ECJ's interpretation of EU law in the Laval case was far from given and therefore hardly predictable. If nothing else, this is illustrated by the 
relatively large divide between the Court of Justice's judgment and the Advocate-General's proposed ruling in the case. The trade unions complied with Swedish legislation. The interim decision of the Labour Court (AD beslut/Labour Court Decision 2004 nr. 111) also supported their industrial action where the Court of Justice ruled that it was unlawful. Nevertheless, the final judgment of Labour Court ruled that the trade unions were liable to pay damages and ordered them to pay substantial damages. The trade unions also had to pay for the opponent's extensive court costs. The question is, however, whether a similar denouement would be possible today, not least bearing in mind that the ILO's Committee of Experts later found that the trade unions' freedom of association had been strongly violated through the damages (Report of the Committee of Experts on the Application of Conventions and Recommendations Report III (Part 1A)).

\subsection{Which path did Sweden take?}

Lex Laval came into force on 15th April 2010. This led to several amendments to the Swedish Posting of Workers Act as well as the CoDetermination Act. I will not go through all of them here; instead, I will only bring up the amendments relating to the issues I have discussed in this article.

Due to Lex Laval, provisions that affect conditions of pay have been introduced into the Swedish Posting of Workers Act. The conditions that can be demanded through industrial action shall concern a clearly defined minimum wage. However, the solution the legislature chose did not include an obligation for the social partners to introduce a minimum wage or the lowest wages. This is still an issue to be resolved by the social partners.

As regards the choice of method for the establishment of wages and other conditions within the hard core, the Laval Inquiry chose to propose a solution within the framework of Article 3.8 in the Posting of Workers Directive. It was the first alternative that the Inquiry opted for, in other words collective agreements that are generally applicable to all similar undertakings in the geographical area and in the profession and trade concerned. 
According to the new legal rule, the conditions that may be demanded through industrial action shall correspond to the conditions in a central collective agreement that is applied throughout Sweden for corresponding employers within the sector in question. The preparatory work on the law makes it clear that all central nationwide sectoral agreements are regarded as applying "in general" to the industry concerned. The sectoral agreement(s), which in each given situation form(s) a reference for demands vis-à-vis companies posting workers to Sweden, is/are to be determined with the guidance of the principle area of application of the agreement.

Saco was satisfied with this solution and believed that the chosen method fits in with the Swedish collective agreement model. It enables the social partners to negotiate the conditions in the collective agreements within the framework of the hard core. Saco pointed out at the same time that in order for the method to be compatible with the Swedish system of collective bargaining, it is also important that the proposal not only departs from the sector in question but also from the category of workers concerned, i.e. "corresponding workers". It might be a question of professional categories, blue-collar workers and white-collar workers, but also university graduates within one sector.

Practical experience of Lex Laval has in principle failed to materialise. Until now, no trade union has taken industrial action supported by the legislation. Therefore, it is difficult to know whether the application of the legislation and the model that was introduced might lead to problems and whether the assessment that all Swedish sectoral agreements fit into the model chosen in accordance with Article 3.8 in the Posting of Workers Directive holds. Instead, the impact of Lex Laval has been indirect as the legislation together with the judgment of the Labour Court have probably checked the fighting spirit of the trade unions. 


\subsection{Epilogue}

Today, early spring 2015, two different Commissions of Inquiry are reviewing the rules on the posting of workers. One Inquiry that was appointed in the autumn of 2012 following an announcement from the Riksdag (the Swedish parliament) is the Parliamentary Posting of Workers Committee, which consists of representatives from the political parties represented in the Riksdag (kommittédirektiv/Terms of Reference 2012:92). The Committee was given additional terms of reference (kommittédirektiv/Terms of Reference 2014:92) by the new government that came to power in the autumn of 2014 . The overall task is to evaluate Lex Laval. In accordance with the additional terms of reference, the Committee must also consider what amendments to the law and any other further measures are required to reinforce the status of collective agreements in situations where workers are posted. The report must be submitted no later than 31st May 2015.

The Social Democrats, who are currently in power with the Green Party, went to the polls promising to tear up Lex Laval and saying that Swedish collective agreements apply fully to everyone working in Sweden. If the government is able to gain support for its proposals, we can expect amendments to Lex Laval and that at least some of the limitations to the Swedish system of collective bargaining which were a consequence of the Laval judgment will be removed.

The task of the second Inquiry, which was appointed in the summer of 2014 (kommittédirektiv/Terms of Reference 2014:81 and additional Terms of Reference 2014:50), is to review the implementation of the EU Directive on the implementation of the Posting of Workers Directive (Directive 2014/67/EU on the application of Directive 96/71/EC concerning the posting of workers in the framework of the provision of services). The report of the Inquiry shall be submitted no later than 31st March 2015.

The future of Lex Laval should also be seen in the light of the criticism put forward by both the ILO's Committee of Experts and the European Committee on Social Rights (the Council of Europe) against the legislation. If the criticism is heeded, the Swedish government must amend Lex Laval.

At the same time there is a lively debate going on in Sweden and the EU on minimum wage legislation. More and more Swedish actors, trade 
unions and researchers believe that Sweden should consider the possibility of introducing a system which includes the universal applicability of collective agreements. So, even if Lex Laval to a large extent found solutions within the framework of the Swedish collective bargaining model and even if we in the future may see further adjustments of our model, the pressure to change has increased. We can only speculate whether we would have seen such a development in the debate without the judgment of the Court of Justice in the Laval case. 



\section{Danish RUT Register}

Flemming Dreesen ${ }^{4}$

\subsection{Introduction $^{5}$}

Foreign enterprises providing services in Denmark and posting workers to Denmark in that connection have had a duty since 2008 to report various items of information to the Register of Foreign Service Providers, the socalled RUT Register. The RUT Register is seen in Denmark as a key tool for authorities and the social partners when it comes to checking foreign enterprises and their employees, when these employees are posted to Denmark.

The requirement for foreign enterprises to pre-register information is also known in other Nordic countries.

The Enforcement Directive from 2014 allows a Member State to require that a service provider established in another Member State "makes a simple declaration to the responsible national competent authorities".

The Posting of Workers Directive was transposed into the Danish Posting of Workers Act of 1999. The Posting of Workers Act includes the solution which is the Danish reaction in particular to the decision of the European Court of Justice in the Laval case and the rules on RUT. The implementation performed is a minimum implementation including in the sense that Denmark has not laid down provisions on minimum wages in accordance with Article 3(1)a of the Directive. At the time of implementation, the social partners agreed that the Directive should not lead to the introduction of a Danish statutory minimum wage or generalised collec-

\footnotetext{
${ }^{4}$ Head of Employment Law at DA, the Danish Employers' Federation.

5 I am not going to use the term "social dumping", since this is an imprecise, value-based concept.
} 
tive agreements; this has also been the case whenever a revision of the Act or the Laval solution has been discussed subsequently.

\subsection{What is RUT?}

\subsubsection{The official register of the Danish state}

Foreign service providers (enterprises) posting wage-earners to Denmark, and foreign self-employed persons are under an obligation to register various items of information with RUT. Reporting is electronic. The rules are specified in particular in Chapter 3a (Section 7(a)-(e)) of the Danish Posting of Workers Act.

Registration with RUT does not release enterprises or employees from any other required registration, e.g. taxes, duties or social security.

The Register's own website states that "the Register of Foreign Service Providers (RUT) is the Danish government's official register for reporting a foreign service". Registration may be done in Danish, German, English and Polish. There are different ways to access the Register: www.virk.dk: The Danish Working Environment Authority, www.posting.dk and the website of the Ministry of Employment.

A number of special services are exempt from registration with RUT. ${ }^{6}$

${ }^{6}$ Participation in seminars and conferences, professional artists and professional athletes and coaches for individual events, business travel, accounting and audits for up to eight days, cabotage runs, as well as company-internal posting for up to eight days which is not in building and construction, farming, forestry and horticulture, cleaning including window cleaning, as well as hotels and catering. 


\subsubsection{Information to be registered}

The foreign enterprise posting workers to Denmark must report the following to the Register:

- The company's name, address, etc.

- The date of provision of the service.

- Workplaces.

- Contact person.

- Sector code and any VAT number abroad.

- The identity of posted employees and the length of the posting period (name, citizenship, identity numbers, etc., date of birth, as well as starting and ending date of the posting period).

As regards its posted employees, the enterprise may also register A1 certificate information on social security and vocational qualifications in accordance with the Qualification Directive.

Anyone performing work in Denmark must - upon request from the Danish Working Environment Authority - state his/her own name and the name of the enterprise for which he/she is working, for use in verifying that the obligation to register with RUT has been met.

A foreign enterprise which for the provision of services in Denmark does not post wage-earners to Denmark (self-employed persons) must also report to the Register.

The information must have been submitted at the same time as the work in Denmark starts. Changes to such information must be submitted no later than first working day after the change was made.

\subsubsection{The contractor's liability}

If the service concerns building and construction, cleaning services or farming, forestry or horticulture, the contracting entity/contractor shares liability for registration with RUT.

The contractor's liability also applies to private individuals (not business operators). The foreign enterprise must submit a receipt of registration with RUT to the contractor. If the contractor approaches the Danish 
Working Environment Authority within three days about failure to register, the contractor shall not be punished.

\subsubsection{Penalties}

Failure to comply with the duty to register, including the contractor's liability, results in a fine. The Danish Working Environment Authority may issue an administrative fine. ${ }^{7}$ In regular cases, the level of the fine is DKK $10,000 .^{8}$

\subsubsection{Use of the information provided}

The Danish Working Environment Authority has principal responsibility for monitoring foreign labour. For example, the Authority will be able to draw on information in the RUT Register in connection with the organisation and performance of its inspection directed at foreign enterprises. The tax authorities draw on the information in the Register to ensure that tax rules are complied with. Other authorities have similar access. In addition, the information provided forms part of statistics.

Some information in the Register is available to the general public. All public authorities have access to all registered information about the enterprise. Others, including private individuals, also have access to information, e.g. about the workplace, but not access to the identity of the employees.

Trade unions thus have insight into the information in RUT. They can use this information to contact the foreign enterprise with a view to entering into a collective agreement, which also includes the possibility of giving notice of intended industrial action.

\footnotetext{
7 The Danish Working Environment Authority may propose a fine to foreign enterprises (penalty notice). If the enterprise will not accept this administratively recommended fine, the case will go to court. The penalty notice is not used towards contractors. Incidentally, the police are responsible for investigations and sanctions on the basis of the information from the Danish Working Environment Authority.

${ }^{8}$ As a result of the fiscal bill for 2015 between the Danish government and parties supporting it, the fine for violating the obligation to register with RUT increases by $100 \%$ the second time the rules are violated.
} 


\subsection{Outline of the development of RUT}

\subsubsection{Enlargement to include eastern and central European Member States}

The establishment of the Register was prompted by the expiry of the transitional scheme from 2004, when the EU was enlarged, following which a work permit and residence permit were required and by Danish conditions when workers from the new eastern and central European Member States came to Denmark to work. The Register was to ensure that an overview could be kept - as a "management tool" - of the number of foreign workers/service providers in Denmark. ${ }^{9}$

The Register replaced corresponding registration according to the tax rules in building and construction. Here, the duty to register was only incumbent on the Danish user company/contractor. ${ }^{10}$

\subsubsection{Balance between foreign and Danish companies}

According to the Parliamentary Bill of 2008 (L 70, Folketinget 2007-08), the purpose of the Register is to ensure a balance between Danish and foreign enterprises, since enterprises which have been established in or have a permanent business address in Denmark are obliged to register. Information about the enterprise and the number of employees is thus available via public registers. The Central Business Register (CVR) includes information about the enterprise, its address and number of employees, and this information is also available to the general public. Corresponding information was not available as regards foreign enterprises posting employees to Denmark.

\footnotetext{
${ }_{9}$ Danish discussions of foreign labour are organised into three elements: A political compromise group, a monitoring group with the participation of civil servants and the social partners, and regular contact meetings, nationally and regionally, between authorities and the social partners on inspection measures. ${ }^{10}$ Sect. $7 \mathrm{E}$ of the Danish Tax Control Act was introduced in 1995, also on the basis of experience with the construction of the Great Belt Link.
} 
The Register gave the authorities improved basic data for a more efficient and targeted inspection to ensure that foreign enterprises and their temporary employees in Denmark also comply with Danish rules, such as working environment legislation and tax and excise legislation.

Furthermore, a number of additional informational items were made available to the general public. According to the Parliamentary Bill, this was directed mainly at trade unions to "also provide the social partners with the possibility of ensuring that posted wage-earners have wage and working conditions that correspond to the level in Denmark."

Later on in 2008, a new provision was entered in Sect. 6 a of the Danish Posting of Workers Directive; this is the Danish follow-up on the decision made by the European Court of Justice, mainly in the Laval case. This provision ensures that trade unions are able to take industrial action, also via information from RUT.

The Register has been modified a number of times.

\subsubsection{Other measures in Denmark relating to foreign workers}

RUT is only one of a series of measures introduced, mainly within the last ten years in Denmark, relating to foreign enterprises and foreign workers. The topics of foreign workers and stricter rules in RUT have been a regular feature on the agenda in Fiscal Bill negotiations in recent years.

\subsection{The legal basis in European law for RUT}

The Parliamentary Bill from 2008 refers to Article 3 of the Posting of Workers Directive, according to which Member States must ensure that posted wage-earners are given the same working conditions and conditions of employment as those which apply in the host Member State. Furthermore, according to Article 5 of the Directive, Member States must ensure compliance with the Directive. The underlying legal basis comes from Articles 56 and 57 of the TFEU on free movement. However, the Enforcement Directive provides a framework in the form of a Directive, see below under 3.5. 


\title{
3.4.1 Simple prior declaration
}

The Parliamentary Bill from 2008 is based mainly on the European Commission communication from 2006 "Guidance on the posting of workers in the framework of the provision of services" $\operatorname{COM}(2006) 159$. On the basis of case law from the European Court of Justice, etc., the Commission reviews the administrative procedures, which host Member States may require in accordance with Community law in order to verify compliance with the provisions of the Posting of Workers Directive concerning working conditions during their posting period.

In its communication, the Commission reaches the following conclusion:

\begin{abstract}
"On the basis of existing case law, the Commission considers that the host Member State, in order to be able to monitor compliance with the conditions of employment laid down in the Directive, should be able to demand, in accordance with the principle of proportionality, that the service provider submits a declaration by the time the work starts, at the latest, which contains information on the workers who have been posted, the type of service they will provide, where it will take place and how long the work will take."
\end{abstract}

In its communication, the Commission also states:

\begin{abstract}
"The purpose of such declarations would appear to be, on the one hand, to enable the national authorities to verify the information on the posting of workers obtained during in situ checks and, on the other, to help the labour inspectorates to conduct risk assessments in order to target their checks on high-risk situations or companies."
\end{abstract}

In its communication, the Commission refers to the European Court of Justice decisions in C-43/93, Vander Elst, C-244/04, the Commission v. Germany, and C- 445/03, the Commission v. Luxembourg. Cases such as C168/04, the European Commission v. Austria, and subsequently C-219/08, the Commission v. Belgium, C- 515/08, Santos Palhota, and C-319/06, the Commission v. Luxembourg, could also be mentioned.

In case C-91/13, Essent, the European Court of Justice in September 2014 referred in an art obiter dictum in grounds 57 and 58 to "a simple prior declaration" as an alternative to other control measures in regard to the posting of workers. In case C-315/13, de Clerq, on Belgian LIMOSA, the 
European Court of Justice stated in December 2014 that liability for the contractor may form part of such a system and also confirmed its own case law, cf. ground 71,11 which includes the possibility of requesting a prior declaration.

The ongoing case C-56/14, De Beukeleer, also concerns liability for the contractor in Belgian LIMOSA. The court submitting the case also addresses recipient rights in the Services Directive. ${ }^{12}$

\subsubsection{Only justified measures}

The European Court of Justice framework for prior registration is "a simple prior declaration," which is not used or obtained for prior control, but for the necessary control to be carried out in connection with performance of the service.

Furthermore, it follows from other case law in the European Court of Justice that control measures required to ensure compliance with requirements which in themselves are based on the common good are justified. However, this control may not exceed the limits of Community law, including the requirement for proportionality, and must not make the free exchange of services an illusion or less attractive.

The decision by the European Court of Justice in C-577/10, the EU Commission v. Belgium, concerned requirements in Belgian LIMOSA of prior registration of self-employed persons, which the European Court of Justice found to be unjustified. The decision from December 2014 in C-513/13, de Clerq, can also be used to illustrate the fact that the Member State must

\footnotetext{
11 ... "that the Court has already held that an obligation imposed on an employer established in another Member State to report beforehand to the host Member State authorities on the presence of one or more deployed workers would be an effective and proportionate measure which would enable those authorities, first, to monitor compliance with the social welfare and wages legislation of the host Member State during the deployment while at the same time taking account of the obligations by which that employer is already bound under the social welfare legislation applicable in the Member State of origin and, secondly, to combat fraud."

12 "Article 19. Prohibited restrictions. Member States may not impose on a recipient requirements which restrict the use of a service supplied by a provider established in another Member State, in particular the following requirements: (a) an obligation to obtain authorisation from or to make a declaration to their competent authorities..."
} 
be able to justify its administration. Belgium was able to do so in this case, and was also able to justify a liability for the contractor in a national arrangement with prior notification (and not, as in RUT, at the time when the service provision begins, at the latest). Conversely, this does not mean that Denmark will be able to introduce this arrangement without documenting that a requirement for prior registration is justified in Denmark.

\title{
3.5 The Enforcement Directive
}

\subsubsection{Article 9 of the Enforcement Directive}

Article 9 (1) gives the following specification:

\begin{abstract}
"Member States may only impose administrative requirements and control measures necessary in order to ensure effective monitoring of compliance with the obligations set out in this Directive and Directive 96/71/EC, provided that these are justified and proportionate in accordance with Union law."
\end{abstract}

In accordance with Article 9(1)(a) of the Enforcement Directive, Member States may introduce:
"an obligation for a service provider established in another Member State to make a simple declaration to the responsible national competent authorities at the latest at the commencement of the service provision, into (one of) the official language(s) of the host Member State, or into (an)other language(s) accepted by the host Member State, containing the relevant information nec- essary in order to allow factual controls at the workplace, including:
(i) The identity of the service provider.
(ii) The anticipated number of clearly identifiable posted workers.
(iii) The persons referred to under points (e) and (f).
(iv) The anticipated duration, envisaged beginning and end date of the posting.
(v) The address(es) of the workplace.
(vi) The nature of the services justifying the posting."

In accordance with Article 9(1)(b)-(f), a Member State may insist that the foreign enterprise appoints a contact person and stores, hands over and 
translates the following documents and makes the following available: employment documents, pay slips, work slips, including information about daily working hours and documentation of wages paid.

As regards requirements other than those mentioned in the Directive, Article 9(2) specifies that Member States may (only) act as follows:

\begin{abstract}
"Member States may impose other administrative requirements and control measures, in the event that situations or new developments arise from which it appears that existing administrative requirements and control measures are not sufficient or efficient to ensure effective monitoring of compliance with the obligations set out in Directive 96/71/EC and this Directive, provided that these are justified and proportionate."
\end{abstract}

\title{
3.5.2 Stricter monitoring by the European Commission
}

In accordance with Article 9, cf. Articles 2-5, the Commission will closely monitor Member States' use of Article 9(1), and, in particular, any additional measures in accordance with Article 9(2), so as to verify compliance with EU legislation.

\subsubsection{The new anchoring in the Enforcement Directive}

The right of Member States to require prior information from foreign service providers was anchored in Articles 56 and 57 of the TFEU, until the coming into force of the Enforcement Directive (most recently confirmed by the European Court of Justice in its decision in C-315/13 de Clerq); however, Article 9 of the Enforcement Directive now provides a legal framework to be complied with. Incidentally, the Enforcement Directive requires additional cooperation among authorities and better enforcement.

The Enforcement Directive only concerns the Posting of Workers Directive, e.g. not prior registration for other reasons. The Directive is based on common EU law, cf. also the introduction to Article 9(1). This must mean that both the requirements which a Member State may make in accordance with Article 9(1)(a), but in particular the requirements introduced by a Member State in accordance with Article 9(2), need to be demonstrated to be justified and proportionate in relation to EU law, including Articles 56 and 57 of the TFEU on free mobility. 
The question is whether, in the view of the European Court of Justice, the Enforcement Directive widens or narrows the right of Member States to request prior information from foreign service providers. It can probably be assumed that, on the one hand, the Enforcement Directive gives Member States firm ground to stand on when they refer to a duty to give information as mentioned in Article 9(1). On the other hand, as regards measures not explicitly mentioned in the Directive, Member States will still be able to refer to common EU law and Article 9(2) of the Directive. In any event there will be more systematic verification of all measures by the European Commission. A case in point in relation to RUT could be the possibility of players other than Danish authorities having access to the information contained in the Register.

\subsection{Registration systems in other States, including Nordic countries}

The duty of foreign service providers to make prior registration is known from other EU Member States. A Commission report from June 2012 said that 18 Member States already had such systems. ${ }^{13}$

\subsubsection{Difficult comparisons ${ }^{14}$}

It can be difficult to distinguish registration done for tax and duty reasons from registration done for labour market reasons.

To this must be added that there may be other documentation requirements, etc., which jointly contribute towards providing the same

\footnotetext{
${ }^{13}$ Study on the protection of workers' rights in subcontracting processes in the European Union Project DG EMPL/B2 - VC/2011/0015.

$14 \mathrm{My}$ basis for comparisons comes from the Internet only. Basically, information could in all cases be submitted in different languages, and always in English. It is important that information about registrations is immediately available on the Internet, cf. also Article 9(4) of the Enforcement Directive: "Member States shall ensure that the procedures and formalities relating to the posting of workers pursuant to this Article can be completed in a user-friendly way by undertakings, at a distance and by electronic means as far as possible."
} 
level of information as prior registration. The information systems of the different countries are thus closely linked to, and can only be justified by, the interaction of the State's overall labour market system, collective law system, tax system, authorities and social partners.

\subsubsection{Sweden}

In 2013, the Swedish Posting of Workers Act introduced a registration system similar to RUT. The foreign enterprise must submit information prior to commencement to the Swedish labour inspectorate about the workplace, workers and a contact person. Foreign enterprises may be penalised in the form of a fine for failure to comply with the rules; the fine is SEK 20,000. Posting up to five days does not require registration. There is public access to information about employer, workplace, contractor and line of industry. Registration is electronic.

\subsubsection{Iceland}

Iceland has a registration system regulated in the Icelandic Posting of Workers Act. This system also seems to correspond to RUT. The foreign enterprise must provide information about the enterprise and the workers. The Department of Labour may ask for additional information. If the posting lasts more than six working days, there is a separate duty for the enterprise to appoint a contact person. Furthermore, liability exists for the contractor. In case of infringement, a per diem fine of up to ISK 100,000 may be imposed.

\subsubsection{Norway}

Norway has a registration system which seems primarily to have a tax objective. In Norway, both the foreign enterprise and the Norwegian contractor must submit information about the use of a foreign enterprise and foreign workers in construction tasks. This information is submitted to the Norwegian tax authorities on the basis of Norwegian tax legislation. The information must be submitted as soon as possible after the contract has been signed and no later than 14 days after performance of the work 
has commenced. The duty to report applies to enterprises and public authorities, but not private individuals. The minimum fine for failing to submit information is NOK 10,000.

\subsubsection{Finland}

Finland has a registration system which seems primarily to have a tax purpose. For example, the tax authorities must be informed if construction workers are posted. Finland also seems to be a case in point demonstrating that interactivity of the different sources of information, etc., may provide the same information as is contained in the RUT Register in Denmark.

In accordance with the Finnish Posting of Workers Act, the enterprise must appoint an enterprise representative, who does not have to be in Finland. This person must have detailed data available at all times on workers and their conditions of employment. The Finnish liability arrangement in regard to public procurement includes a due diligence procedure, which involves an obligation for the foreign enterprise to state and document wages and working conditions before a contract is awarded.

\subsubsection{Other EU States}

As mentioned, registers such as RUT are also known in other Member States. The Danish government has intervened in support of Belgian LIMOSA. This applies to C-577/10, the European Commission against Belgium, and C-315/13, De Clerq, as well as C-56/14, De Beukeleer, on liability for the contractor. 


\subsection{Number of registrations in RUT}

\subsubsection{Number of entries}

This information is available at www.jobindsats.dk, where a monthly update is provided.

There is no doubt that there still is - and particularly in the first years after the establishment of RUT there was - under-registration in RUT.

Information in the RUT Register goes back only three years. Selfemployed persons are totalled together with wage-earners.

\begin{tabular}{llrl} 
Number of enterprises in RUT & & \\
& & Enterprises & Average number of persons per enterprise \\
\hline & & 2,839 & 5.2 \\
The whole & 2011 & 4,033 & 5.1 \\
country & 2012 & 3,960 & 4.9 \\
& 2013 & 3,964 & 4.0 \\
\hline
\end{tabular}

Source: RUT.

Number of wage-earners and self-employed persons in RUT

\begin{tabular}{llll} 
& & Persons & FTEs \\
The whole country & 2011 & 14,823 & 3,543 \\
& 2012 & 20,606 & 4,954 \\
& 2013 & 19,374 & 4,522 \\
& Q1-Q2 2014 & 16,052 & 7,271 \\
\hline
\end{tabular}

Source: RUT.

The majority of enterprises and posted persons come from Poland, Germany and Lithuania. Among the Nordic countries, Sweden ranks highest.

The average posting period is twelve weeks. The largest group works in building and construction. Another large group works in farming and forestry. There are practically no registrations in the hotel and catering sector. 


\subsubsection{Number of violation cases}

Registration check is an item for tax authorities, the police and the Working Environment Authority.

There is no complete picture of sanctions. There is an overlap between figures from the police and public prosecutor and the Working Environment Authority.

From 2011 until mid-2014, 847 cases were addressed by the police. Most cases concern service providers.

From 1st July 2013, when the Working Environment Authority were given the possibility of settling cases by means of a penalty notice, until 1st April 2014, a total of 177 administrative penalty notices were issued. Of these, 28 were accepted by the foreign enterprise, which thus admitted to the issue. Another 88 cases were turned over to the police due to a failure to accept or objections. During the same period, the Working Environment Authority passed on 330 cases to the police, which were cases not suitable for a penalty notice. In the period from 2012 to Q1 2014, the Authority passed on 760 cases to the police for charges to be made.

In its memo of 24th November 2014, the Working Environment Authority stresses - in regard to the result of authority cooperation on foreign labour - that according to their general impression, foreign companies registered with RUT comply with working environment legislation to a higher extent than foreign enterprises which fail to comply with their duty to register with RUT.

\subsection{Challenges for RUT}

During the negotiations in the Council of Ministers on the Enforcement Directive, the Danish government worked to ensure that registers such as RUT would be anchored in the Directive. Following a joint wish from DA ( the Confederation of Danish Employers), and LO (the Danish Confederation of Trade Unions), the Danish government also worked to ensure that 
RUT could be used as an element in the due diligence procedure which Member States may introduce in regard to responsibilities in accordance with Article 12(2) of the Directive, cf. Consideration 37. This is now to be integrated into the Danish implementation process. ${ }^{15}$

In this provision, the Enforcement Directive does not address the question of registration of self-employed persons, cf. also C-577/10, the European Commission against Belgium. ${ }^{16}$ Furthermore, the Enforcement Directive does not include liability for the contractor. See above in 3.4. on C315/13, De Clerq.

In its contribution in C-56/14, on Belgian LIMOSA, the Danish government has referred to the interpretation of European Court of Justice case law, stating that this is supported also by Article 9 of the Enforcement Directive. ${ }^{17}$

The Danish press has reported that the Polish government has approached the European Commission with regard to RUT. According to the information available, this also concerned access of the general public to information in RUT, including access for competitors and the trade union movement. Public access to information in the RUT Register is thus one of the special Danish elements which cannot be read from Article 9 of the Enforcement Directive.

In September 2013, the Ministry of Employment informed Folketinget that there is an ongoing informal dialogue with the Commission regarding the duty to register self-employed persons with RUT.

\footnotetext{
15 The intention is that if the Danish enterprise or contractor in an arrangement with contractor liability in accordance with Article 12 of the Directive is able to substantiate that the foreign service provider has been registered with RUT, the Danish contractor is free from liability, since both authorities and the trade union movement have access to either the necessary control measures or labour law cover.

${ }^{16}$ In regard to the decision by the European Court of Justice in C-577/10, the Danish government has stated that the Court: “... recognises in principle the possibility of requiring prior declaration from selfemployed persons without employees. However, the judgment specifies that Belgium has not argued well enough to substantiate that the arrangement is proportionate" (memo of 9th May 2013, BEU (Employment Committee), 2012-13, appendix 195).

17 Ministry of Foreign Affairs memo of 19th May 2104, EUU (European Affairs Committee) 2013-2014, general part, appendix 457.
} 


\section{The Nordic Model and the EU: Implementation of Directive 96/71/EC - the Icelandic Experience}

Magnús Norðdahl ${ }^{18}$

\subsection{Is there such a thing as one Nordic model?}

A common characteristic of the Nordic countries is what is referred to as the Nordic labour-market model. It is characterised by relatively strong trade unions, which organise between $55 \%$ and $86 \%$ of all wage-earners. Other shared characteristics include a mixture of centralised and local rounds of bargaining; a joint wage policy based on solidarity; wellestablished tripartite councils; a strong, respected obligation to keep the peace; the prominent role of a public conciliation board; incorporation of wage-earners' general rights and legal protection into legislation and labour-market agreements; and, finally, the absence of a statutory minimum wage. In spite of these shared main features, the Nordic countries are different. Iceland is different in a number of ways: there is a high level of organisation membership on the private labour market, where $86 \%$ of wage-earners are members of a trade union and $70 \%$ of employers belong to an employers' organisation; the scope of labour law is relatively small; labour-market agreements become law and automatically become gener-

${ }^{18}$ Chief legal advisor at ASÍ, the Icelandic Trade Union Congress. 
ally applicable (automatic extension, erga omnes) as regards minimum conditions which the Icelandic trade unions see as a tool in the fight against "social dumping"; wage formation is flexible; and, finally, there is relatively low job protection.

To this must be added that Iceland is a small country, remotely located, without any shared physical borders with other countries. Iceland is not a member of the European Union (EU), but does form part of the joint economic area through the agreement on the European Economic Area (EEA), so the country has relatively limited influence on developments in the EU. This poses other challenges for the Icelandic labour market, but also other opportunities on the labour market than in EU Member States, including the Nordic countries that are members of the EU.

The deviations mentioned here do not mean that the other Nordic are more or less identical. For example, both Norway and Finland have ways of implementing the erga omnes principle of labour-market agreements, while the social partners in Denmark play a more extensive role in the implementation of EU law than is the case in the other Nordic countries, except Iceland.

Therefore, even if the labour-market models of the Nordic countries are not identical, researchers find that they are sufficiently similar to be defined as one model with strong shared features. The labour-market model is closely connected to what is called the Nordic welfare system and actually forms an integral part of that system. These two systems supplement each other and together make up the Nordic model. This model gives a fine explanation of how the Nordic countries have succeeded in protecting their basic values during and after the economic crisis of recent decades and how they have all succeeded in minimising unemployment. (Simon Sturn 2013. Are corporatist labour markets different? Labour market regimes and unemployment in OECD countries. International Labour Review. Vol. 152. Bls. 237). When discussing labour-market models and the implementation of EU legal acts, however, it should be taken into consideration that the Nordic EEA states (Iceland and Norway) hold a special position as regards the implementation of EU legal acts. Judgments in the Icelandic and Norwegian Supreme Courts clearly show that the courts of EEA states have the possibility - and permission - to assume broader 
authority in protecting their labour-market models than is the case in the other Nordic countries when it comes to EU legislation (see Chapter 2).

This is the backdrop against which an account is given below of the step-by-step implementation of Directive No. 96/71/EC in Iceland.

\subsection{EEA law and national legislation}

The interaction between Icelandic legislation and EEA legal acts is basically different from the interaction between EU law and the national legislation of EU Member States.

The main rule in EEA legislation on this matter is to be found in protocol 35 of the EEA Agreement, which states: "For cases of possible conflicts between implemented EEA rules and other statutory provisions, the EFTA States undertake to introduce, if necessary, a statutory provision to the effect that EEA rules prevail in these cases." The EEA Court has interpreted the protocol to mean that an EEA rule which has been incorporated into national legislation takes priority over a conflicting provision in national legislation (cf., for example, case E-1/07).

The protocol was incorporated into Icelandic law as a rule of law interpretation; however, Article 3 of Act No. 2/1993 states the following: "Wherever relevant, laws and rules must be interpreted in accordance with the EEA Agreement and the rules based on said Agreement." In some cases, the Icelandic Supreme Court has addressed this law provision. The first time this was done was in 2003 (HRD 477/2002), when the Supreme Court stated that the rule of the EEA Agreement on a ban against specific taxation should be deemed a special rule taking precedence over an older law provision which was in conflict with the special rule. In subsequent judgments, the Icelandic Supreme Court approached the subject differently; a judgment from January 2013 (HRD 10/2013) specifies the following:

\footnotetext{
"Article 3 of Act No. 2/1993 states that, to the extent relevant, laws and rules should be interpreted in accordance with the EEA Agreement and the rules based on said Agreement. The Supreme Court judgment of 9th December 2010, in case no. 79/2010, states that, in the nature of things, the interpretation of law, cf. Article 3 of Act No. 1/1993, is also a matter of the language of Icelandic laws reflecting as much a possible the significance given in and as much as possible corresponding to the joint
} 
rules to apply within the European Economic Area. However, this kind of law interpretation cannot lead to disregarding the working of Icelandic law, as it says in the judgment" [my emphasis].

This means, quite simply, that EEA rules do not take precedence over Icelandic law and it also means that, when implementing EEA law, Iceland reserves the right to have more flexibility than EU Member States.

The Norwegian Supreme Court has taken a similar view to this. A case from 2000, (HR-2000-49-B) dealt with the provisions of Norwegian road traffic legislation on damages; however, in an advisory statement from the EEA Court, these provisions were deemed to partially infringe EEA law as well as three specific EU Directives, which Norway felt it had implemented. In its conclusion, the Norwegian Supreme Court stated that:

“.... Norwegian law is governed by a so-called presumption principle, which means that an Act should be interpreted in line with our international law obligations to the extent possible, thereby also in line with the three EEA Directives. In this case, the provision concerned could hardly be understood in different ways. If the provision were to be disregarded, this would mean going beyond a reasonable interpretation of the provision; this would in practice mean that the non-implemented Directives would be given direct effect with priority over formal law. It would constitute a problem for legal persons if they could not act on the basis of Norwegian law."

This is the same conclusion arrived at by the Icelandic Supreme Court, i.e. that EEA law does not have priority over national legislation.

In a subsequent judgment from March 2013 (HR-2013-0469-A), the Norwegian Supreme Court dealt "with the significance of what the judgment refers to as 'the Norwegian working life model'", and whether this model and specific parts of it (the erga omnes effect of labour-market agreements in accordance with a specific decision) were protected under the provisions of Article 3.10 of Directive No. 96/71/EC on the posting of workers. The mentioned Article deals with exceptions from the rules of the Directive on the basis of the provisions of basic principles of law (public policy provision) and states the following: "This Directive shall not preclude the application by Member States, in compliance with the Treaty, to national undertakings and to the undertakings of other States, on a basis of equality of treatment, of terms and conditions of employment on matters other than those referred to in the first subparagraph of para- 
graph 1 in the case of public policy provisions." The Norwegian Supreme Court concluded that this could be the case, and the judgment states the following (item 161): "The question is whether provisions of significance to stability of such a basic structure of society can be deemed to concern 'public policy' in the sense of the Directive. Based on the statement given by the Department in proposition No. 88 (2008-2009) to the Odelsting, the answer to this question is largely affirmative in my view."

In the same judgment, the Norwegian Supreme Court also utilised its latitude to deviate from the advisory statements of the EEA Court, but the judgment states the following (item 94):

".... that the Supreme Court shall not take the statement from the EFTA Court as a basis without review, but has the authority and duty to independently decide whether and to which extent this should be done. Against this background, I cannot see that the Supreme Court would formally be deprived of the right to base its decision on a different viewpoint."

This relation between EEA law and the national legislation of the individual country, reflected in the judgments from the Supreme Courts of Iceland and Norway, is completely different from the relation between EU law and the legislation of the individual Member State, and thus also from the rules that apply in Denmark, Sweden and Finland by virtue of their membership of the EU. The European Court of Justice made it clear long ago that EU law takes priority over Member State legislation (Costa v. ENEL, Case No. 6/64), and that EU rules may have direct legal effect in national legislation without having been implemented. Furthermore, it cannot be disregarded that the EU's competence in the social field was markedly enhanced through the Amsterdam Treaty in 1997 (which is not binding on the EEA countries), nor should the development in EU law be disregarded which means that, because of the principle of harmonisation, EU Directives may gain an "indirect horizontal effect".

It is thus my conclusion that both Iceland and Norway have more latitude than the other Nordic countries when it comes to protecting their various labour-market models, and thus the Nordic labour-market model, in light of the development of EU law, which the EEA countries see as a threat to their labour-market models. This view does not involve a position on whether Iceland's situation is better outside the EU than it would 
be inside. This is an open question, which will not be answered until the question can be clarified in the membership negotiations with the EU which have presently been put on hold.

\subsection{Implementation of Directive 96/71/EC in Iceland}

\subsubsection{Original implementation through Act No. 54/2001}

Work was carried out in 1999 and 2000 on the coming into effect of the Directive; the Icelandic Trade Union Congress (ASÍ) participated in all stages of this preparation. When a Parliamentary Bill on the posting of workers was introduced in 2001, ASÍ criticised the contents of the Bill for not making a sufficient effort to protect the Icelandic labour market. ASI's statement on the Bill includes the following:

\footnotetext{
"In this country, the main rule is that agreed wages and other working conditions for wage-earners according to labour-market agreements are minimum conditions which the individual wage-earner cannot renounce. As will be known, this is specified in Article 1 of Act No. 55/1980. This Act applies to all wage-earners working in Iceland, no matter whether the wage payer is Icelandic or foreign and whether the person belongs in Iceland, in the EEA, or elsewhere."
}

Against this background, ASÍ proposed that all provisions of Icelandic labour-market agreements apply to wages and other conditions to the extent they have an erga omnes effect in accordance with Act No. 55/1980, and in light of the fact that there is a ban on treating people differently because of nationality, posted workers must be paid the same wages as others in the Icelandic labour market, i.e. the market wages in force at any given time. This view did not prevail, and relatively simple legislation on posted workers was adopted, where the only reference was to the most important statutory rules on minimum conditions, working environment, etc. 


\subsubsection{Agreement on foreigners in the Icelandic labour market, 2004}

In the years that followed, a large number of foreign workers came to Iceland, mainly in connection with large CHP plants and expansion in the building sector. A number of cases on infringement of foreign workers' rights came up, including cases on posted workers. As a result, in 2004 ASÍ and the Central Employer Federation (SA) adopted an agreement on foreign workers in the Icelandic labour market (http://www.asi.is/ \%C3\%BEinn-rettur/foreign-workers/english/). In this agreement, the social partners declared their joint project to be the preservation of the existing arrangements in the labour market, and stated that they intend to jointly work to ensure that enterprises using foreign labour for production or services pay wages and comply with working conditions that are in accordance with applicable labour-market agreements and laws in Iceland. The agreement contains provisions concerning information for trade union representatives and a consultation committee of the two parties to the agreement, the task of which would be to resolve conflicts in individual cases. Subsequently, the authorities amended Act No. 55/1980 on wageearners' working conditions to ensure that agreements between the social partners on the handling of conflicts in regard to wage-earners' wages and conditions of employment in the Icelandic labour market are in accordance with the provisions of the Act and that labour-market agreements would have the same validity as agreements on wages and working conditions, i.e. they would have the same erga omnes effect for the whole labour market as collective agreements.

\subsubsection{Preparation and adoption of Act No. 45/2007.}

The lessons learned from the implementation of the agreement in 2004, as well as growing pressure on the Icelandic labour-market model in subsequent years, prompted the Minister for Social Affairs to establish a working group with the social partners to review the situation for foreigners in the Icelandic labour market. Among the proposals from the working group was a revision of Act No. 54/2001, which had originally implemented Directive No. 96/71/EC. The working group felt it was important to strengthen the basis of the existing labour-market system as regards for- 
eign companies posting their employees temporarily in Iceland in connection with the performance of services on the basis of the EEA Agreement. Subsequently, new package legislation was passed in the form of Act No. $45 / 2007$, which contained a number of basic changes.

The new legislation assumes that foreign companies domiciled in another country within the EEA and wishing to perform services in Iceland on the basis of the EEA Agreement for more than ten working days within a period of twelve months are to submit specific information to the Labour Directorate (Vinnumálastofnun) concerning their activities in Iceland not later than eight days after the commencement of each service provision period. Companies posting their employees in the country to perform services for four weeks or less within a twelve-month period form an exception to the above-mentioned notification obligation, provided that the service consists of specialised assembly and set-up, inspection or repair of equipment. Furthermore, companies which normally have six or more employees posted in Iceland, performing services for more than four weeks within a twelvemonth period, are to have a local, dedicated contact person who represents the company vis-à-vis the authorities and social partners. In addition, companies which receive services are obliged to ensure that the foreign companies with which they have concluded contracts have submitted the basic information required by law to the Labour Directorate (Vinnumálastofnun). This information includes the company's name, information about its domicile in its home country showing the name of the company's representative, the address in the home country, the nature of the services to be provided, their VAT number or other similar documentation of the company's activities in its home country, documenting that the company operates lawfully in its home country within the line of business concerned in accordance with that country's national legislation, and, finally, the name of the company receiving the service and the central business registration number of that company or similar identification. Furthermore, a list of all employees who will be working on the company's behalf in Iceland must be submitted, stating their name, date of birth, home address, citizenship, documentation of the persons' social security in their home country (E-101), place of residence in Iceland and the planned length of stay, as well as a work certificate as required. If an employee is not a resident of the EEA, a valid work permit from the home country must be submitted together with conformation that 
the employees in Iceland have accident insurance, as defined in legislation. The Act also contains clear provisions on the right of posted workers to fixed pay in accordance with an employment contract (not minimum pay in accordance with a labour-market agreement) in case of illness or accident, i.e. provisions which reflect the basic rights incorporated into labourmarket agreements on the private labour market. The Act also contains provisions on the inspection to be carried out by the Labour Directorate (Vinnumálastofnun), as well as on the notification obligation which is incumbent on both the company delivering and the company receiving the service concerned towards the Directorate, which includes the duty to submit contracts of employment, and, finally, a provision on authority to stop the work if compliance with the Act is not ensured.

In the preparation of the Act, ASÍ had substantial influence on the contents of the Act and accepted the ultimate outcome.

\subsubsection{ESA's and Iceland's reactions}

After the new Act was adopted, ESA, the EFTA Surveillance Authority, reviewed it and concluded in a reasoned statement that certain provisions infringe Article 36 of the EEA Agreement and Directive No. 96/71/EC, one of the reasons being that the Act contains requirements which are comparable to a prior authorisation requirement for being allowed to start up an enterprise in the country. The following detailed comments were made:

- A service provider must submit information to the Labour Directorate (Vinnumálastofnun) eight days before commencing the performance of the services concerned.

- The Labour Directive must confirm in writing its receipt of the documents which the service provider is obliged to submit to the receiving company before provision of the service may start.

- A company is not authorised to perform services in Iceland if it fails to inform the Labour Directive of its representative or replacement of the said representative.

- The provisions of the Act on an employee's right to wages during illness and in case of an accident and on accident insurance in case of a fatality, permanent injury or temporary loss of working capacity, are 
not part of the working conditions assumed by the European Parliament and the Council's Directive No. 96/71/EC on the work of posted workers in connection with services, cf. Article 3(3)(a)-(g) of the Directive.

Following consultation with the social partners, the Icelandic Parliament, Altinget, decided to accommodate some of ESA's comments. Act No. $45 / 2007$ was subsequently amended; it is thus constitutes sufficient information for companies posting workers in Iceland on the basis of Directive No. 96/71/EC to submit information the same day as the work commences in Iceland. The information rule on conformation of social security in the home country was simplified in that proof other than form E-101 may qualify and in that the Labour Directive is now obliged to confirm receipt of the documentation within two days. The obligation for companies was changed correspondingly. A special provision was added to the Act on per diem fines if companies do not rectify deficiencies as requested by Vinnumálastofnun. The primary reason given for these changes was a reference to the general rules on proportionality in the central administration, cf. Article 12 of the Public Administration Act, Act No. $37 / 1993$.

Amendments to the provisions of the Act on workers' rights in connection with illness and accident - as requested by ESA, cf. item 4 above were not adopted. A report on the proposed amendments to the Act contains the following comment:

\footnotetext{
"According to [ESA], these provisions constitute an obstacle to the free exchange of services on the basis of Article 36 in the Agreement on the European Economic Area, since the contents of said provisions do not form part of the working conditions assumed by European Parliament and Council Directive No. 96/71/EC on posted workers in connection with services, $\mathrm{cf}$. Article 3(3)(a)-(g) of the Directive. However, it must be assumed that the mentioned provisions of the Act result in labour-market agreement rights in the Icelandic labour market which form part of wage-earners' minimum conditions, which means that these provisions provide important protection of wage-earners working in this country. With the purpose of guaranteeing that foreign workers enjoy the minimum rights and conditions which apply in the Iceland labour market in the same way as others who work here, it has thus been considered important to maintain these provisions in legislation [my emphasis]. Furthermore, it is also deemed important that the contents
} 
of these provisions apply, unless the employee has achieved more favourable conditions in his or her employment contract with the company concerned, through a labour-market agreement or by virtue of legislation in the state where the person normally works."

In other words, Altinget has reserved the right for Iceland to protect an important part of the Icelandic labour-market model; consequently, all wage-earners in Iceland must enjoy the same minimum rights, of which rights during illness and accident form an integral part. ESA's reaction was to file a case against Iceland before the EEA Court.

\subsubsection{Judgment in case E-12/10 and Iceland's reaction}

ESA based its lawsuit basically on the argument that the provision on the right to benefits during illness and in case of accident was outside the minimum-wage concept defined in Article 3(1) of the Directive and was not part of the total listing. Instead, it should form part of the provision on social security in Regulation No. 1408/71. Iceland based its defence primarily on the argument that provisions on wages during illness and in case of accident come under the minimum wage concept defined in Article 3(1) of the Directive and that provisions on accident insurance come under the provisions of national legislation on compensation and insurance; these provisions are not covered by the Directive and were thus warranted. Furthermore, the defence was based on the argument that both parts can be justified with reference to the exception in Article 3(10) of the Directive on basic principles of law (public policy). The EFTA Court found that Article 3(1) of Directive 1 contained an exhaustive list of the working and employment conditions which an EEA state may insist that companies domiciled in another EEA state must respect, when they post workers to work in its territory. The listing included "minimum wage and overtime pay". The Court found that the payment of wages in case of illness and accident according to Icelandic legislation would not come under the concept of minimum wage in the sense of the Directive, since the Directive assumes that wages in case of illness and accident are based on fixed pay, but not the minimum wage. Furthermore, the Court found that the provisions of the Act on compulsory accident insurance concern working conditions, but not national legislation regarding compensation and accident 
insurance, and that, consequently, the provisions were not covered by the total listing made in Article 3(1) of the Directive. Finally, the Court concluded that the Icelandic rules on workers' right to wages in case of illness or accident could not be justified on the basis of general principles of law, since Iceland had not demonstrated that such rules were necessary in order to meet a real, current threat to basic interests of Icelandic society.

Following close consultations with the social partners, Altinget decided to accept the judgment and its conclusion concerning compulsory accident insurance and thus removed the relevant provisions from Act No. 45/2007. The adaptation of the Act in regard to wages during illness and accident was minimised in the sense that reference is now made to labour-market agreement wages instead of fixed wages, which is in accordance with the provisions of Article 1 of Act No. 55/1980.

\subsection{Conclusion}

Based on the EEA agreement, it has been argued that Iceland and Norway are better able to oppose EU legislation than can be expected from the Nordic countries which are members of the EU. This could mean that Iceland's and Norway's position is better than that of the other Nordic countries when it comes to protecting the Nordic model - a model, which involves integrated interaction between the labour-market and welfare models built up in these countries in recent decades.

It is in this light the Icelandic approach from the outset should be seen, which was that Directive No. 96/71/EC should be implemented in a relatively independent way and endeavours should be made to ensure that such implementation had the least possible influence on the legal and communicative rules in force in the Icelandic labour market. In line with the Nordic tradition, the social partners were key players in the process and had a close, strong relation to the authorities when things became heated. In this process, the level of accommodation was always as low as possible when it came to accommodating what was seen to be a clear, complete listing in Article 3 of the Directive, as well as to reasoned statements from ESA and the judgment of the EEA Court. Throughout the process, ASÍ's purpose was to ensure in the best way possible that conditions 
for workers posted in Iceland are the same as those generally in force in the Icelandic labour market. The process succeeded in making minimum implementation of the Directive in the national legislation that ranks higher than EEA rules. In the light of the lessons learned, implementation was subsequently resumed and recommendations were made regarding important obligations for the companies which post workers to Iceland, just as inspection was introduced to ensure the workers' rights are protected in accordance with Icelandic legislation and the labour-market agreements which also constitute the minimum conditions for all wageearners in Iceland. 



\section{Does EU legislation Enable Airlines to Discard the Nordic Labour-Market Model?}

Christen Horn Johannessen ${ }^{19}$

\subsection{The Nordic labour-market model is sustainable and defensible}

Norwegian air transport has faced some new challenges in recent years. If the other Nordic countries have not run into them yet, I assume they soon will.

There are two circumstances that are particularly challenging to the Nordic model, the first being that traditional Norwegian aviation is being moved to wholly owned subsidiaries or companies outside of the Nordic region while continuing to serve the same air traffic routes and the same passengers. The second circumstance is related to foreign companies establishing new operations in Norway to compete in our market.

In the first example, the Norwegian parent company can try to "cannibalise" their own Norwegian operations by replacing them with operations formally located outside of the Nordic model. In the second example, the Nordic model is challenged by external companies that are based on a wholly different corporate culture and regulations than those comprising our model. The question is whether EU legislation impedes the defence of the Nordic model. 
In both examples developments result in unionised, permanentlyemployed labour being replaced by non-unionised temporary or agency workers. Meanwhile, a number of the new companies actively obstruct the exercise of the right to organise, which undermines a pillar of the Norwegian labour-market model as described in the Norwegian Ministry of Labour and Social Affairs' Report to the Storting no. 29 (2010-2011):

\footnotetext{
"Strong organisations, universal welfare schemes and comprehensive tripartite cooperation are often emphasised as preconditions for the good results we have achieved, including a smoothly functioning world of work, a sound working environment, high labour-market participation, low unemployment rates and high productivity."
}

Airlines that wish to exploit the passenger market created by this model, while simultaneously not being part of the same model, will undermine and erode it. The greater the extent of such "freeloading", the faster the erosion. For this reason, it is vital that such abuse of the Nordic labourmarket model be stemmed.

"The competitive edge" that employers can gain by disregarding the Nordic model for cooperation is short-sighted and not very well thought through. The value of loyal, satisfied, stable and competent workers is a far bigger competitive advantage than the short-sighted cost-efficiency to be obtained by not entering into formal industrial relations.

Norwegian Air Shuttle is a company that has proved its ability to establish itself in a highly competitive market precisely through its respect for and cooperation with trade unions. Furthermore, the company's success is based on a passenger market resulting from the Nordic model. Its possibilities for further success within the same model depend on fair conditions for competition.

It should not be necessary nor possible for any company to compete in this market without respecting the Norwegian system and Norwegian rules and regulations. Collective agreements and Norwegian international private law can be used to defend the Nordic labour-market model, even in the light of EU law and the four freedoms. 


\subsection{It is possible to use industrial action to preserve operations that are the basis for the collective agreement}

\subsubsection{The position of collective agreements and their effect under Norwegian law}

Collective agreements have a strong position in Norway and regulate, in principle, all wage and working conditions. Entering into a collective agreement also imposes a fundamental duty to act loyally and in good faith on both parties.

The collective agreement and the duty of loyalty that come with it continue to apply after the agreement has formally expired and the parties sit down to re-negotiate. In Norway, this is known as the ultra-activity of collective agreements and its legal basis is Section 8(3) of the Industrial Disputes Act. Such extension the validity of collective agreements is also recognised by other European countries, cf. the decision handed down by the Court of Justice of the European Union (CJEU) in September 2014, C$328 / 13$, on the safeguarding of employees' rights in the event of transfers of undertakings.

A collective agreement is normally restricted to a category of workers and is based on the activity or "business" the employer uses these workers to carry out. In the context of labour legislation, this activity is called a "business" (it takes a business to run a business). This business is the very basis of the collective agreement, without which the collective agreement would erode so that both the agreement and the individual employment relationship in the end would cease to exist. For this reason, the basis of the collective agreement and the employer's good faith in interpreting and executing its provisions are decisive, precisely to avoid it being circumvented through formal moves under company law.

During the validity of collective agreements, the basic obligation under Section 8(1) of the Labour Disputes Act to keep industrial peace will prevent trade unions from resorting to strike. During the period of validity of a collective agreement, any breach of the agreement or the duty of loyalty on the part of the employer must thus be met with legal action, as in any other legal dispute. However, for this very reason it has become necessary 
for Norwegian trade unions in civil aviation to enter into one-year or short-term agreements in order for this type of breach to be addressed relatively quickly or during the re-negotiation of agreements, during which time the duty to keep industrial peace does not apply.

In trade disputes - "dispute between a trade union and an employer or employers' association concerning the organisation of future employment and wage terms or other working conditions that are not subject to a collective agreement or will replace a previous collective agreement," cf. Section 1(j) of the Labour Disputes Act - the governing principle in Norwegian law is that the use of industrial action is not subject to the proportionality principle or the principle of reasonableness. Accordingly, in Norway, trade unions can, in principle, call a strike to advance any claim that the union deems to be in its interest.

If a Norwegian airline wishes to "move" wholly or in part its business that is based on the Norwegian passenger market to establishments outside of Norway, the question arises of whether this basic right to take collective action is as unrestricted, cf. the issue of the cross-border element and EU law. The question is not whether the right to take collective action is protected under such circumstances but how much it will be restricted in the light of the requirement under EU law of legitimate purpose and proportionality.

\subsubsection{EU and EEA law obviously apply to the parties to the collective agreements but so do the fundamental human rights of which the right to take industrial action is a part}

In the situation described above, the four EU freedoms must be considered in the light of Viking Line (C-438/05) and Laval (C-341/05) doctrine.

In the Viking Line case, two fundamental rights were simultaneously recognised and juxtaposed, i.e. the right to take collective action and the freedom of establishment. In the grounds for its judgement (77) the CJEU acknowledges the right to take collective action as a possible restriction on the freedom of establishment. In paragraph 79, the Court states that economic and social and labour purposes must, in case of conflict, be specifically "balanced" on a case-by-case basis. The use of collective action as 
a measure to advance one's interests can, in other words, be judged to have grounds, even when it entails a restriction of the freedom of establishment. Where this line is drawn depends on the assessment of the possible gravity of the threat to jobs represented by the establishment, and what other less invasive means organisations have at their disposal, cf. the proportionality principle.

In 2008, British Airways (BA) wanted to set up a subsidiary in France without any collective agreement with the trade union, BALPA. BALPA wanted to stop BA and served a notice to strike. BA countered by threatening to file a substantial claim for damages, arguing that the walk-out would violate its freedom of establishment. BALPA abandoned its planned action in the light of the two above-mentioned CJEU rulings and in fear of liability running into the millions.

After the Viking and Laval judgments, the European Court of Human Rights (ECtHR) handed down a decision that bolsters the position of the right to collective bargaining and thus also the right to industrial action pursuant to Article 11 of the ECHR. The ruling in Demir and Baykara v Tyrkia (2008 ECtHR 1345) has been called a watershed in this context, cf. paragraphs 145 and 154:

Consequently, the Court considers that, having regard to the developments in labour law, both international and national, and to the practice of Contracting States in such matters, the right to bargain collectively with the employer has, in principle, become one of the essential elements of the "right to form and to join trade unions for the protection of [one's] interests" set forth in Article 11 of the Convention, it being understood that States remain free to organise their system so as, if appropriate, to grant special status to representative trade unions.

The outcome of a future balancing by the CJEU of the relevant considerations is, as a result of this ruling, considerably less certain than what appeared to be the case in the wake of Viking/Laval. 


\subsubsection{Legitimate purpose and within the principle of proportionality in relation to the freedom of establishment}

An airline established in Norway is of course free to establish new business outside of Norway and outside of the provisions and scope of the collective agreement. Nevertheless, it is a breach of the fundamental principle of loyalty in industrial relations if the company reverses its production to start passenger transport from another base and with the support of establishments outside of Norway. It would also be in breach of the duty of loyalty if it continues to convey passengers from the same base in Norway but through a subsidiary incorporated in another country. In both cases the company is "cannibalising" its own production already established and under a collective agreement.

Under these conditions, unions should be able to defend the basis of their collective agreement - the business on which the collective agreement is based - without entering into conflict with the four EU freedoms. Collective action to prevent the erosion and circumvention of collective agreements would therefore be defensible. There is ample reason to believe that a reorganisation of business with no other purpose than circumventing the collective agreement should yield to the fundamental right to collective action on which the Nordic model of industrial relations is based, cf. the corresponding substance-over-form principle in the context of taxation. (E-3/13 and E-20/13 paragraphs 164 and 165).

As pointed out by the EFTA Court in E-3/13 and E-20/13 paragraphs 96 and 97, the concept of "establishment" is wide and covers any entity "that carries on real and genuine economic activities ... for an indefinite period." This is a functional approach that fits nicely with the approach to the concept of "business" in item 1.2 above. When the real economic activities remain identical, despite formal changes, we are not faced with any real new establishment of the kind that EEA Article 31 and the free flow are meant to protect.

Mirroring this, a trade union should, according to the circumstances, also be able to organise the employees of a foreign company that set up business based in Norway and demand the execution of a Norwegian collective agreement. The exercise of collective rights towards this employer would not constitute a restriction of the freedom of establishment as such 
demands represent a fundamental right within all free-market states. The company could thus risk being met with similar demands in all of the countries in which it is established in this way, cf. no discrimination or arrangement special to Norway. This is how the freedom of establishment is safeguarded, cf. "national treatment in the host state".

\subsubsection{The significance of workers' and businesses' links to Norway}

Cases in which workers linked to the business in question must be deemed to still have Norway as the centre of their activities differ fundamentally from those in which the business relocates in the traditional sense, as in relocating production to a low-cost country in such a way that operations are moved there. This also differs from workers being temporarily posted to finalise work under an international contract. For people working in the aviation business, the relevant service or operation will necessarily have to be carried out in Norway, no matter where the employer is domiciled.

Workers' access to the exercise of fundamental rights, including the right to demand collective bargaining and to launch collective action as described in item 1.2, will also be affected by the question of which country the relevant employment relationships of the business are most closely connected to. Whether or not the workers of a company must be deemed to actually work in or from a base in Norway could be decisive for the court's decision when weighing the facts. This brings us to the other main issue, linked to the choice of law and of legal venue, i.e. the country on whose legislation and courts the aircrew's contractual relationship is based. This could prove decisive when assessing the question that heads this article. 


\subsection{The "Flying Dutchmen of labour law" - cause for deep concern}

In recent years, Ryanair has challenged incumbent airlines in Norway, and since 2010 particularly on flights to and from Moss (Rygge). Its establishment has pressured the way in which Norwegian airlines run their business. It is therefore important - also for ensuring a "level playing field" that companies setting up within the Nordic model relate to the society in which they wish to operate and make money.

Ryanair dominates Rygge airport. The company has tried to run this base by completely ignoring Norwegian law and the Nordic industrial relations model. Ryanair claims that the four freedoms and other principles allow them to establish and run this type of business in Norway so long as they observe Irish law and the Irish system. Its main argument is that it is an Irish company, their workers are hired on Irish contracts by an Irish contractual counterpart, they are taxed by Ireland, have their social rights there, and they carry out their work on planes registered in Ireland. All instructions and all influence over working and employment conditions originate from Ireland and regulations on the posting of workers and free flow impede their being subject to Norwegian law and Norwegian courts.

The problem with the system Ryanair wants to impose is that very few of those living and working in Norway for Ryanair have any real possibility of enjoying the rights and advantages that follow from Irish law and the Irish system. As there is no connection between the individual employment relationship and the system that aims to protect workers, the crews become the "flying Dutchmen of labour law, condemned to fly without any jurisdiction in which they can seek redress", as described by Lord Hoffmann in a case heard by the House of Lords, cf. Marie Nesvik's article, "Where do airline crews work?" in LoR nr. 7 for 2013.

The Norwegian trade union movement spotted the problems created by the Ryanair model early on and started organising many of those who work for Ryanair in Norway. Their affiliation and the work of trade unions have given Ryanair considerable opposition and the company has been dragged through two rounds in Norwegian courts. This opposition is indispensable to the exercise of fundamental rights and to the functioning of 
regulations and the system as assumed by the legislator. This would not have been possible without the trade unions, which provide individuals with the necessary professional and financial support to endure these protracted court proceedings.

\subsubsection{EU regulations on social protection}

On 22nd May 2012, the EU adopted special regulations (EU No 465/2012) to strengthen flight crews' social rights. The essence of the amendments is clearly stated in paragraph 4 of the preamble, which reads that social security should be based on "a special rule whereby the concept of «home base becomes the criterion for determining the applicable legislation for flight crew members." Through this amendment, the EU has ensured, in this particular field, that the country of the home base - i.e. where you turn up for work and start and finish your period of work - is also where you have your social protection. This not only plugs one of the gaps in the system, it is also one of several elements pointing towards the general choice of law and jurisdiction being the country in which flight crews have their place of work.

So far, the Nordic countries have not agreed on how to interpret the regulation, as expressed, inter alia, by a letter of 11th November 2014 from the Danish Ministry for Equality in relation to social protection for cabin crews employed by Norwegian. Upon the change of employer, confusion arose as to where the flight crews were socially protected. The Ministry stated in this context that this was due to "unequal application of the choice of law in connection with social protection."

\subsubsection{EU law on choice of court and applicable law}

Norway is bound by the Lugano Convention on jurisdiction and the enforcement of judgments. Article 19(2)(a) corresponds to Article 21(b)(i) of the Brussels I regulation (in force 10th January 2015) and should be interpreted in the same way. Both provisions should be understood to mean that a worker may institute civil proceedings "in the courts for the place where or from where the employee habitually carries out his work or in the courts for the last place where he did so; ...". The amendment 
simply codifies the jurisprudence of the CJEU so there is no new provision that enters into force in January 2015.

The questions of choice of law and courts are, in principle, two different issues that are determined on the basis of two separate regulations. Norway has no specific, written provisions on the choice of applicable law but recent jurisprudence, cf. Rt. 2011 page 531 paragraph (46), found that Norway, in consideration of the need for a unified system of law, should adhere to the Community's established and predictable regulations on applicable law. These follow from the Rome I Regulation (CE), cf. Article $8(2)$, which states that the employment contract "shall be governed by the law of the country in which or, failing that, from which the employee habitually carries out his/her work in performance of the contract" (my underlining). Article 8 is a further development of the former Article 6, which lacked the words "from which". The Commission said as follows about the amendment:

\begin{abstract}
"This change will make it possible to apply the rule to personnel working on board aircraft, if there is a fixed base from which work is organised and where the personnel perform other obligations in relation to the employer (registration, safety checks)."
\end{abstract}

\title{
5.3.3 The Ryanair I and Ryanair II cases in Norway
}

Two legal actions have been filed against Ryanair on behalf of Rygge airport staff. In both cases, Ryanair lost on the issue of choice of jurisdiction.

In the Ryanair II case, the question of choice of jurisdiction was twice appealed to the Supreme Court. In its rulings, the Supreme Court (Rt. 2013 p. 1589) twice refuted a number of Ryanair's main arguments. In the first instance, the Supreme Court in paragraph (43) disproves the argument of it being decisive that all in-flight work take place in the territory of the country of registration, cf. the Chicago Convention:

Ryanair has submitted that the Court of Appeals was in error in setting aside the fact that A carried out most of his work on board planes that are registered in Ireland, and that, pursuant to the Chicago Convention, Irish planes are Irish territory. The Committee does not find that the Court was in error in setting aside this fact, which to the employees must appear to be a mere formality. Attaching importance to this fact would entail a considera- 
ble weakening of the workers' protection under Article $19^{*}(2)(a),{ }^{20}$ whereby one would need clear grounds in sources of law on which to base the judgment [my emphasis].

Secondly, the Supreme Court in paragraph (44) refutes Ryanair's line of argument that Ryanair's staff serving in Norway could be moved at any point in time to other bases and that, consequently, as employees of an Irish company, they should be considered as posted workers:

The Committee does not find for the submission that the interpretation of the Court of Appeals is in breach of the Posting Directive or that it entails a restriction on the free movement of services. The Committee will here limit itself to establishing that the applicable provisions have been applied in keeping with the concept of law on which the CJEU has based the parallel provision.

The litigant parties had made reference to the two transport cases Koelzsch in C-29/10 and Voogsgeerd C-384/10, on choice of applicable law and it was these two cases that the Supreme Court referred to.

In addition, Ryanair has consistently argued strongly in relation to both choice of law and venue that the clauses in the individual employment contract on Irish law and Irish jurisdiction should be decisive. The Supreme Court did comment on these issues. In its preliminary ruling of 5th March 2014, the Court of Appeals attached scant importance, on a general basis, to such formalities, as "It is, to a large extent, a matter of a more formal character in which employees probably have little possibility of influencing the choice of solutions."

In the wake of the above, the Court of Appeals has made reference to the Schlecker case, C-64/12, in which a narrow exemption was applicable as all links other than the workplace itself pointed to the workers' country of origin and residence. In Schlecker, the Court adopted the Advocate-General's opinion. The Advocate-General emphasised that social links, and not the formal ties unilaterally imposed by the employer, should be determining.

20 https://www.lovdata.no/pro/\#reference/lov/2005-06-17-90/lk/a19 
Community regulations on applicable law are in themselves an effective protection against workers being forced in this manner to apply law other than that which follows from the connection criteria, cf. Rome I Regulation Article 8 (1), second sentence:

\footnotetext{
"Such a choice of law may not, however, have the result of depriving the employee of the protection afforded to him by provisions that cannot be derogated from by agreement under the law that, in the absence of choice, would have been applicable pursuant to paragraphs 2, 3 and 4 of this Article."
}

As to the question of choice of law in Ryanair, the District Court ruled that "the case is most closely connected to Norway and that Norwegian law is thus applicable to the litigation proceedings." This matter was not even appealed by Ryanair and the case was subsequently settled out of court.

In Ryanair II, the District Court ruled that the dispute be resolved according to Norwegian law but the judgment is not final and enforceable, and we expect that it will also have to find its final solution in the Supreme Court.

In parallel with these proceedings against Ryanair, the Norwegian Data Protection Authority has discussed Ryanair's use of CCTV, in respect of which the Civil Aviation Authority Norway carried out two inspections of its operations in Norway, and the Norwegian tax authorities have also shown an interest in employees who, pursuant to their individual employment contracts, have committed to living within one hour from the airport. Civil Aviation Authority Norway referred in their report of 11th July 2013 to the fact that:

"The Ministry of Labour and the Ministry of Transport and Communication have jointly stated that aircrew are covered by this act when they start and end their roster in Norway, without regard to where the main activity is taking place or where the airline have its principal place of business."

\subsubsection{What will be the consequences of the Ryanair case?}

The court has now finally decided that Ryanair is under the obligation of appearing in a Norwegian court. The company runs its business in Norway from a labour-law perspective and it employ workers in this context. Ryanair is also under an obligation to respect important public aspects of the Nordic model. Its workers have social rights in Norway and the company 
must respect public law provisions on inspection and taxation. Workers may affiliate with Norwegian trade unions and said trade unions may demand collective agreements that cover operations in Norway.

Despite the fact that Supreme Court still has not taken any position on the choice of law in respect of the affected workers in the Ryanair II case, it is now clear that Ryanair, where relevant, will have to observe Norwegian law and submit to the jurisdiction of Norwegian courts.

\subsection{EU law does not protect fair competition and fundamental rights}

It is important to firmly place Ryanair as an establishment operating in Norway because this will protect the people who work for them and also because it means that everyone established in this country will have to play by the same rules. The purpose of the internal market is not to erode the basis of that market, but to facilitate healthy competition. It would also be contrary to EU law to facilitate employment relationships in which people have to work and live in a social environment whose benefits are denied to them, and to set aside fundamental mechanisms for collective bargaining and agreements that are ensured by the ECHR and the ECtHR. By upholding the Nordic labour-market model, airlines are relieved of the need to compete at the expense of the system and the welfare that their business is based upon. It also safeguards workers' right to work, live and develop a social life in the place where they actually work.

The answer to the question that heads this article should therefore be a resounding "NO". 



\section{Collective Bargaining, Freedom of Association and the Impact of the EEA Agreement on Icelandic Labour Law}

Hrafnhildur Stefánsdóttir ${ }^{21}$

\subsection{Collective bargaining in Iceland and cooperation between the social partners}

Collective agreements concluded between trade unions and their federations and employers, i.e. the social partners, have had a decisive impact on the development of the Icelandic labour market since 1938, when the Act on Trade Unions and Industrial Dispute came into force. The Act, which is still in force, concerns trade unions, their competence, collective bargaining, industrial action and the Labour Court, and is primarily based on the Nordic model. A basic agreement has never been concluded, however. Trade unions are a legal contracting party in collective bargaining regarding the establishment of members' minimum wages and working conditions. Individual trade-union members are at the same time bound by the trade union's statutes and agreements. Moreover, only the trade unions have the right to take industrial action according to the Act. As regards 
public sector workers, there is special legislation for their collective agreements, which largely corresponds with the 1938 Act.

Collective agreements have had general applicability (erga omnes) according to the law since 1974. The 1974 Act on Working Terms of Wage Earners was adopted because the judgments of the Supreme Court had changed earlier assumptions that collective agreements entered into pursuant to the 1938 Act were binding for all employers and employees regardless of membership of trade unions that concluded the agreements. The view was that this created an uncertainty that might lead to a deterioration of worker conditions as well as the competitiveness of organised employers. Therefore, there was consensus regarding the legislation.

The Act on the Working Terms of Wage Earners in force stipulates that pay and other working conditions that are determined by the social partners in collective agreements are minimum conditions - regardless of gender, nationality or length of employment - for all employees in each respective sector covered by the collective agreement. Agreements between individual employees and their employers on conditions inferior to those stipulated in the general collective agreements are invalid. General collective agreements are agreements that a trade union or trade-union federation concludes with an employer organisation. These are generally applicable in the area covered by the collective agreement. On the other hand, collective agreements that only cover one or several specific companies are not generally applicable since the scope of the collective agreement is limited to the specific companies.

In addition, the social partners have been cooperating on different social issues for some time. The most important issue is the pension system established by the collective agreements in 1969, which is still governed by the social partners, cf. the Act on Mandatory Pension Insurance and on Activities of Pension Funds from 1997. The Work Rehabilitation Fund was founded in the collective agreements of 2008 with the aim of facilitating a return to working life after illness or accident, cf. the Work Rehabilitation Fund Act from 2012. The social partners also cooperate on education and training and there are fixed-term collaboration projects on job placement and counselling, for example.

Moreover, the trade unions also run special sick-leave benefit funds for their members. These are funded through an employer's contribution of 
$1 \%$, as stipulated in the collective agreements. According to the statutes of the Icelandic Confederation of Labour, the main rule is that when a member is sick or has been involved in an accident, it is the affiliate's sick-leave funds that must pay the member at least $80 \%$ of his/her wages for 120 days after the right to sick-leave benefits paid by the employer has expired. Apart from that, the rules of the funds may differ. The white-collar workers' fund, for example, makes payments for up to 270 days. The sickleave funds also make payments for seriously ill children and spouses as well as different benefits. Sick-leave benefits are not paid by the Social Insurance Administration. Hence, union membership is important for individual workers.

The level of affiliation is $85 \%$, which can be explained by the benefits mentioned above and the priority clauses in the collective agreements.

\subsection{Freedom of association and priority clauses in collective agreements}

Priority clauses that oblige employers to allow workers who are full members of the relevant trade union to have "priority to all general work when this is demanded and union members, who are fully capable of doing the work involved, are available" are included in most collective agreements in the private labour market in Iceland. These clauses existed already before the Act on Trade Unions and Industrial Disputes came into force in 1938 and are regarded as complying with the provisions of the law. Moreover, the employer shall, in accordance with collective agreements and the law, collect trade-union dues of the workers and transfer these to the trade union as long as they are members of a trade union, cf. the Supreme Court 390/2010.

According to the Icelandic Confederation of Labour, the main aim of priority clauses in the collective agreements is to promote unionisation. Regardless of whether priority clauses lead to an increase in membership, the Confederation does not believe that workers are excluded from work. This is firstly because the trade unions are obliged by law to grant membership to the workers an employer wishes to employ. And secondly because priority is limited by the access to skilled workers who are full 
members. Thus, unionised workers do not take automatic precedence over non-unionised workers. Therefore, the view of the Confederation is that priority clauses have an impact on the organisation of labour and are intended to facilitate an enhanced social discipline and increased cohesion regarding terms and conditions in the sector in question.

The legality of the priority clauses became the subject of discussion when the Constitution of Iceland was amended in 1995, since there was a dispute as to whether priority clauses were compatible with the new freedom of association provision in Article 74.2 of the Constitution which reads as follows:

"No one may be obliged to be a member of any association. Membership of an association may, however, be made obligatory by law if this is necessary for enabling an association to discharge its functions in the public interest or on account of the rights of others."

The preparatory works refer to the fact that, according to the judgment of the European Court of Human Rights in the Sigurjonsson case from 30th June 1993, Iceland was in breach of its obligations in accordance with Article 11 of the European Convention by obliging taxi drivers to be members of a trade union. In the preparatory work, an amendment was made stipulating that Article 74.2 in the Constitution on the right not to be a member includes the main rule that no one may be obliged to become a member of an association and that the rule can only be disregarded if so warranted by the circumstances described in the Article.

This amendment to the Constitution prompted serious criticism from the trade-union movement during the passage of the bill through Althing (the Icelandic Parliament). Accordingly, the Parliamentary Committee on the Constitution pointed out that it had emerged that priority clauses included in most collective agreements had not been mentioned at all in the preparatory work. Consequently, the legal situation could have proven to be rather precarious.

Furthermore, the Parliamentary Committee on the Constitution pointed out that, according to the wording of Article 74.2, no one may be obliged to be a member of an association through a law or decision by an authority. Therefore, what you are obliged to do according to freely concluded agreements, including collective agreements, is considered not to be regulated. As regards trade unions and membership thereof, the Com- 
mittee also pointed out that workers are not obliged to be a member of a trade union according to current legislation. Hence, the circumstances concerning trade unions are not mentioned in Article 74.2 and thus no amendments to the rules on membership of such organisations have been proposed. It was considered that there were special grounds to mention that the priority clauses in collective agreements do not lead to an obligation to be a member as provided in Article 74.2.

This led the Parliamentary Committee on the Constitution to consider that an approval of the provisions in Article 74.2 did not entail any change to the legal situation in the labour market regarding priority clauses and the employers' obligations to pay fees to trade unions as stipulated in collective agreements. The report was unanimous without reservation.

The Labour Court has relied on the above-mentioned report in later judgments. In case $7 / 2006$, the Court notes that the legislature has assumed, when introducing the amendment in question to the Constitution, that priority clauses in the labour market remained unchanged. This emerged after the European Convention was transposed into Icelandic law in 1994. According to the Court, it cannot be assumed that the judgment of the European Court of Human Rights from 11th January 2006, in the case of Sørensen and Rasmussen vs. Denmark has led to any changes regarding the interpretation since in that particular case it was the importance of the obligation to be a member that was tested by the Court, and thus the background is not comparable.

Here the Labour Court refers to the difference between the previou sly mentioned priority clauses and exclusive agreements according to which all employees who are covered by the agreement are obliged to be a member of a trade union. In conjunction with the amendment of the Constitution discussed above, a line was drawn between the two. According to the explanation given by the Parliamentary Committee on the Constitution, priority clauses were compatible with the new provisions on the freedom of association in the Constitution while the exclusive agreements that were still included in certain collective agreements were regarded as unlawful. The Icelandic Confederation of Labour consequently amended its statutes and banned exclusive clauses in the statutes of the member organisations. 
At the same time, the Labour Court's view has been that priority applies, not only when a worker is being employed but also when he or she is being dismissed, cf. 2/2002 and 7/2006. Thus, the Court rejected the view that priority clauses should be interpreted taking Article 74.2 of the Constitution into consideration and saw the dismissal of members in each relevant trade union while keeping on members of other trade unions as a breach of the collective agreements, even if their employment was not in breach of the priority provision in the collective agreements. Bearing the discussion above in mind, this interpretation is extremely dubious. As regards the judgment of the European Court of Human Rights in the Sørensen and Rasmussen case, Elín Blöndal (Icelandic Law Journal 2.2006) mentions that in Iceland, provisions on the obligation to be a member of an association in a collective agreement and priority clauses have been differentiated while, in the judgment in the Sørensen and Rasmussen case, you can read that that differentiation bears no importance according to Article 11 of the European Convention.

It should be noted that in all legal cases, it is employers that have based their action on the rules of freedom of association in Article 74.2 of the Constitution and the European Convention. The freedom of association of employees does not seem to have been a controversial political issue in recent years.

Priority clauses in collective agreements also have a certain stabilising function on Icelandic labour law since they entail the fact that the employer is in reality bound to recognise only one trade union as party to collective bargaining, cf. the judgment of the Labour Court 9/2009. The background is that trade union $B$ brought an action against company and trade union $\mathrm{A}$ and demanded recognition as a party to collective bargaining on behalf of its members vis-à-vis the company. The grounds for the judgment refer to the fact that trade union $\mathrm{A}$ had concluded a collective agreement on behalf of its members at the company for the same work that trade union B was demanding an agreement for. According to the collective agreement, the company was bound by the priority of the members of trade union A. Due to the priority clause, the company was in fact bound to recognise only one trade union within each industry in each respective area covered by the trade union. The main rule in the private labour market is thus that one and the same trade union has the mandate 
to be party to collective bargaining for each industry in the area covered by the agreement.

These rules are used in such a way as to limit the number of contracting parties in the private labour market. Collective Agreements for Public Sector Employees Act, on the other hand, stipulate certain formal requirements that trade unions must fulfil in order to have the right to negotiate vis-à-vis public employers.

\subsection{Influence of the EEA Agreement and the implementation of Labour Law Directives}

EEA membership has had a considerable influence on Icelandic labour law, primarily employment law. Until now, this had not resulted in any major changes to basic principles, because EEA rules have mostly consisted of amendments to legislation already in force. Formal information and consultation processes were, for example, not common nor had trade unions made any demands that they be introduced. Moreover, the Working Time Directive brought with it other foreign additions, particularly as regards the rules on maximum number of working hours per week, which were previously considered to be sufficiently covered by the rules on daily rest periods. The rules on the transfer of undertakings were also new and alien to Iceland, as well as the rest of the Nordic Area.

A special committee was appointed in 1993 with the aim of considering the implementation of the EEA rules in the area of labour law. The committee had an advisory capacity regarding the government's drafting of proposals on the implementation of new EEA rules. Apart from the delegates from the Ministries of Welfare, Finance and Foreign Affairs, there were also representatives from the social partners on the committee, i.e. from the Icelandic Confederation of Labour, the Federation of State and Municipal Employees (BSRB) and the Confederation of Icelandic Employers (now SA Business Iceland), Through the committee and subsequently countless tripartite meetings with the Ministries on the implementation of each Directive, the social partners exerted considerable influence on the implementation of the Labour Law Directives, despite the fact that the cooperation has not been particularly formal. The option of implementing the Directives 
through collective agreements has also been used when the parties have so wished and been able to come to an agreement.

The Directives on collective redundancies were implemented through legislation from the beginning. A new law on collective redundancies was adopted in 2000, due to the implementation of Directive 98/59/EC, without any other amendments than those required by the Directive. The same procedure was applied to the implementation of Directive 2001/23/EC, relating to the safeguarding of employees' rights in the event of transfers of undertakings, which was also implemented through legislation. The subject content of both these Directives was new to Icelandic labour law, despite the fact that employers had previously been obliged to notify the authorities of collective redundancies. Even if the information and consultation process was regarded as alien by employers, few cases regarding collective redundancies have been brought before the courts. This might be partly due to the fact that companies have voluntarily corrected their mistakes. The Act on Transfer of Undertakings proved to be more difficult which led to about ten cases being heard by the Supreme Court between 2001 and 2006. Most of the disputes dealt with whether an undertaking had been transferred according to the law.

The implementation of Directive 2002/14/EC, establishing a general framework for informing and consulting employees, proved to be more difficult. As already mentioned, there was no tradition of formal information and consultation processes, apart from the relatively new rules on collective redundancies. Since 1938, employees had had the possibility of having a shop steward at the workplace with the task of receiving complaints from employees and conveying wishes about improvements if the complaints were considered fair. With the Acts on Collective Redundancies, Transfer of Undertakings and not least on Information and Consultation in Undertakings, the shop stewards were given a new and different role in conjunction with redundancies and changes to the company's operations that they did not have before. At the same time the employers are now required to implement the statutory information and consultation process.

Direct contact between trade unions and employers regarding HR issues without the shop steward as an intermediary, has, however, been common for a long time. In addition, shop stewards are not bound by confidentiality beyond what is included in the collective agreements and the 
Acts on Collective Redundancies, and Information and Consultations. As stipulated in the Act on Collective Redundancies, shop stewards shall treat the information they receive in accordance with the law as confidential. As regards the Act on Information and Consultation, the employer can demand that the information provided shall remain confidential based on the legitimate interests of the company.

Initially, the Consultation Committee wished the Directive on information and consultation to be implemented through collective agreements. This proved not to be possible as the social partners were unable to reach an agreement. Since businesses did not have the same tradition regarding information and consultation as in neighbouring countries, the Act was mainly based on the text of the Directive. At the same time, the Act is partially semi-compulsory since it is possible to conclude an agreement on the information and consultation process in the company with each respective trade union or the employees' representatives. Thus, the Confederation of Labour and Business Iceland concluded a collective agreement on the establishment of information and consultation processes in companies in 2008. Despite the attention received and lengthy discussions between the social partners in conjunction with the implementation of the Directive, the Act has aroused little interest. There have been no apparent breaches of the obligation to provide information and consultation. Breaches of the Act on Information and Consultation can lead to fines.

As regards the Directive on the approximation of the law of the Member States relating to the protection of employees in the event of the insolvency of their employer, now 2008/94/EC, it was presumed that the legislation already in force was sufficient. This proved not to be the case as regards demands from certain relatives of the representatives of the undertakings, according to the EFTA Court, E-9/97. Moreover, the EFTA Court confirmed the basic rule about the liability of the state being a part of the EEA Agreement and that the parties to the EEA Agreement shall ensure that compensation is paid to an individual for damage incurred because a state has not fully implemented provisions in a Directive that form a part of the EEA Agreement. Consequently, in its interpretation of the provisions of the EEA Agreement, the Icelandic Supreme Court has consequently established that the advisory statement by the EFTA Court should be taken into account unless something emerges that gives reason to deviate from it. In accord- 
ance with the Constitution, however, it is the Icelandic courts that shall determine whether liability for compensation has sufficient support in the law in accordance with Icelandic law, cf. H236/1999.

The Working Time Directive 93/104/EC was implemented in collective agreements in 1996 and the rules became subsequently statutory since they entailed amendments to the rules on working hours in both the collective agreements and the Act on the Working Environment. The Consultation Committee had previously tried to assess the impact of the Working Time Directive and recommended that the social partners were given the opportunity to come to an agreement and to try to adapt the rules of the Directive to the conditions in the Icelandic labour market.

The organisation of working hours is generally based on collective agreements, which also include provisions on minimum rest periods. In accordance with the Act on the Working Environment, the more detailed determination of the provisions on working hours within the framework of the law has been transferred to the social partners, and it is assumed that they have a great deal of room in which to manoeuvre to conclude agreements within the framework stipulated in the Working Time Directive. The possible exemptions in the Working Time Directive have been used in agreements. The partners agreed on lower reference periods for the calculation of average working hours and permission to shorten the period of rest under special circumstances conditional on the granting of corresponding rest. The limitations regarding the number of working hours permitted per week was new and was not received positively by either employers or employees, at least not to begin with. The reference period for the calculation of the average working hours per week is in accordance with the six months in the collective agreements with the option of being extended to twelve months, provided that such a decision is based on special objective circumstances and is approved by the national confederation of the labour organisation in question. The so-called opt-out provision in the Directive has not been used.

The rules in the Directive on the protection of young people at work, EEC 94/33, were introduced into the Act on the Working Environment. The holiday provisions were already covered by the Holiday Allowance Act and the collective agreements. The rules in the collective agreements on compensatory holidays due to illness abroad has since been changed 
due to comments from the ESA, EFTA's supervisory body. The social partners concluded a collective agreement in 1996 on the employers' obligation to draw up written employment contracts or a written confirmation of employment for the implementation of Directive 91/533/EC. The ESA later remarked on the implementation since there were no provisions on sanctions. This led to provisions on the compensatory responsibility of employers being introduced in the collective agreements in 2013. Moreover, the social partners in the private labour market concluded collective agreements for the implementation of the Directive on part-time work in 2002. The public employees did not manage to reach an agreement with their employers, however, which led to the Directive on part-time work being implemented in law instead.

The other Directives have been implemented in Icelandic law with new legislation. Moreover, the agreements between the social partners at European level, which have been concluded within the framework of the social dialogue without being transformed into Directives, are the responsibility of the contracting parties. Their member organisations shall implement the agreements in accordance with the practice that prevails between employees and employers in each respective country. In Iceland, the Confederation of Labour and Business Iceland comprises the organisations concerned.

The Framework Agreement on Telework was the first collective agreement of this type. The agreement was concluded in Iceland in 2006 through collective bargaining between the Confederation of Labour and Business Iceland. Like other Icelandic collective agreements, it includes binding minimum rules on the rights and obligations of the employees. Other European agreements have been concluded under the same conditions. 



\section{Last in, First out? The Agency Work Directive and the Swedish Staffing Industry as Part of the Swedish Labour- Market Model}

Gabriella Sebardt ${ }^{22}$

\subsection{Introduction}

The Agency Work Directive - Directive 2008/104/EC of the European Parliament and of the Council of 19th November 2008 on temporary agency work - has been described as a dream Directive for legal experts, particularly for those in the northern parts of the Union. As the final product of a process and negotiations that have taken decades, the Directive is full of the ambiguities and inconsistencies so loved by that profession. Moreover, in the Nordic Area, there are few things that excite people as much as when labour-market regulation is not managed by the social partners. The issue of posted workers has clearly shown what happens when the legislative development of the EU clashes with national interests and traditions. Since

\footnotetext{
22 Employer policy and public affairs expert at Almega (former head of secretariat and legal counsel at the Swedish Staffing Agencies, one of seven service sector federations in Almega, the trade and employer organisation for the service sector).
} 
there are far more agency workers than posted workers, there is now a huge risk that we will see much of the same happening.

In fact, this article aims to analyse a case where a national labourmarket regulation model clashes with that of the EU. The Swedish staffing industry will serve as the epicentre in this discussion for the forces released by the Agency Work Directive. This contribution is worded as a question: Will the Swedish staffing industry, as a consequence of the Directive, be subjected to the "last in, first out" principle, which is well known in labour law; in other words, will it be the relative newcomer who is also the first to leave the Swedish labour-market model?

The text is set up as follows. This introduction is followed by a presentation of the Swedish staffing industry as it has been integrated into the Swedish model in Section 1.2 The Staffing Industry in the Swedish Model. Thereafter, Section 1.3 The Implementation of the Agency Work Directive in Sweden deals with the difficulties that implementation has entailed. Section 1.4 Threats and Opportunities, analyses the potential courses of development that the Directive may give rise to. Finally, Section 1.5 Concluding Remarks summarises the discussion while trying to look ahead to the future, always so hard to envisage. As emerges below, this is being written at a time when several potentially game-changing events are just around the corner.

\subsection{The Staffing Industry in the Swedish Model}

The Swedish staffing industry's entry into the Swedish model began as early as the late 1970s, when the first collective agreements were concluded for staff working at the offices of staffing agencies, or stationary staff. As concerns itinerant staff, i.e. employees who worked for the user undertakings, they had to wait until 1988, although this was in fact three years before the phenomenon was legalised.

The fact of the matter was that for about forty years the authorities had fought, albeit sporadically, against the women who, through their writing agencies, had laid the foundations of the industry in Sweden from the 1950s onwards (Johnson 2010). Since agency work in Sweden became part of the employment service concept in a distinctly Swedish fashion, 
and since the main idea for most of the 20th century was to have a public employment service monopoly, the operations of these pioneers did not fit into the picture at all. For almost 50 years there was also a ban against agency work, the breach of which could lead to either a fine or a prison sentence. It was, however, never a matter of the latter, although the women mentioned above were fined on a number of occasions. Therefore, the development of the industry stands out in a description of the development of labour market policy during the last century in a rather interesting way.

When legalisation was followed by deregulation in the early 1990s, there was room for the agency sector to grow and establish itself as an industry. Until the turn of the century, trade and employer issues were pursued separately, but in 2003 a trade and employer federation was set up, Bemanningsföretagen - the Swedish Staffing Agencies (www.bemanningsforetagen.se). Three years earlier, a collective agreement had been concluded with all the LO (the Swedish Trade Union Confederation) unions, which meant that the industry was also starting to develop outside the white-collar sector. Until then, the latter had been the dominant sector due to the origins of the industry in the above-mentioned writing agencies.

Today, the vast majority of Swedish agency workers are employed by one of the approximately 500 member companies of the trade and employer federation. The federation has five central collective agreements and thus thirty-odd labour organisations as counterparts, presumably a record in the Swedish labour market. Consequently, collective-agreement coverage in the Swedish staffing industry is much more extensive than for the Swedish labour market as a whole.

An additional driving force behind this high level of affiliation is the authorisation of the Swedish Staffing Agencies (www.tryggbemanning.se), which has developed into a hallmark of serious business in the area. This is a bipartite set-up where both companies and trade unions are represented on the Authorisation Board which drafts decisions that are subsequently finally approved or rejected by the Board of the Swedish Staffing Agencies. The system was established in 2004 and means that the companies providing the staffing services are members of the Federation and that they meet certain requirements. Authorisation has been compulsory for membership of the Swedish Staffing Agencies since 2009, and only 
start-ups can be members without authorisation during their establishment phase. All members, however, must have collective agreements for the areas in which they operate. Moreover, they must comply with certain fundamental membership conditions which are applicable to all. One of the most important conditions is to be financially sound.

It is therefore no exaggeration to say that the Swedish staffing industry has been fully integrated into the Swedish labour-market model. The conditions of employment and work in the industry thus also comply with the norms that apply in general to the Swedish labour market, including both the types of employment and remuneration principles. Open-ended employment is the norm in the Swedish staffing industry and wages are in line either with the average earnings at the user undertaking (the LO sector) or are differentiated and individual (the fundamental principle in the white-collar sector in Sweden). What mainly distinguishes the staffing industry's collective agreements from those in other sectors is the need for rules for the placement of employees at user undertakings as well as wages between assignments, unless a set monthly salary has been agreed (which is possible in the white-collar sector).

As regards wages between assignments, "guarantee pay", the main idea is that the staffing agency as an employer must not transfer the cost of non-booked time to society as unemployment benefits. Therefore, the length of the employment contract does not follow the length of the assignment unless allowed for this by rules in the collective agreement (i.e. there are grounds for fixed-term employment), as is the case for most other sectors in the Swedish labour market. Consequently, Swedish staffing agencies have also been given the chance to develop their operations on a commercial basis, in the same way as other undertakings. This means that they have also been given the preconditions to take full responsibility as employers, just like any other company. This is sometimes referred to as the Swedish staffing agency model where it has been possible to conclude long-term business contracts, which have in turn created a situation where long-term employment contracts have been possible, and temporary worker agencies are regarded as independent businesses with their own salaries and conditions.

In contrast, the staffing industry in many other EU countries consists instead of a short-term employment sector, which fully complies with the 
terms and conditions of employment at the user undertakings, amongst other things because long-term placements at user undertakings are not actually permitted. When agency work was legalised in Sweden in 1991, there were also grounds for the use of agency work and time caps on assignments at user undertakings, which created a less than ideal situation in relation to the business contracts. However, this was done away with the following year and the amount of special legislation for agency work has also been limited since then, at least until recently.

\subsection{The Implementation of the Agency Work Directive in Sweden}

The implementation of the Agency Work Directive in Sweden has led to a number of difficulties for the parties concerned. On the one hand, because it is designed in such a way so that it does not fit in with the Swedish labourmarket model, and on the other, because there has been no political majority to ensure a smooth ride through parliament. This is discussed below.

\subsubsection{The Design of the Directive}

As has already been mentioned, it took a long time before the Agency Work Directive was adopted in the EU. The path was lined with different attempts at regulation and thus the Directive developed in such a way as to make the final product difficult to access. For example, those labourmarket models that are worst suited for the accepted principles - German, Scandinavian and British - have been exempted from the application of certain parts of the Directive. Since these exemptions have been introduced at different points in time, they are not easy to interpret, particularly if read together. As a direct consequence of this, the impact of the Directive has varied enormously between the different Member States.

History has also provided the Directive with two aims: firstly, the protection of agency workers and later also the recognition of staffing agencies as legitimate employers contributing to job creation and a wellfunctioning labour market. The keys are Articles 5 and 4 of the Directive which deal with the tools for this: the equal treatment of agency workers 
based on the conditions that would apply to direct employment at the user undertaking, and a review of the restrictions and prohibitions which may have been imposed on agency work, i.e. the conditions for the use of agency work. The logic in this is that many restrictions on agency work have been introduced to protect the worker group in question, and they thus become redundant when a general protection rule - the principle of equal treatment - becomes the main rule in the EU. Only restrictions that are justifiable on the grounds of general interest are still acceptable. Exactly what is included in the latter concept and what effects it will have has become to some extent a demarcation line. More about that below.

When, after almost thirty years, the Agency Work Directive was finally adopted by the Council in June 2008, the month after a tripartite agreement had been reached in the British labour market, the Swedish staffing industry had already noted that the regulation was rather superfluous. As described above, at that stage, the industry had been fully integrated into the Swedish model with well-established systems for both the protection of agency workers, i.e. comparable employment and working conditions, and for the recognition of staffing agencies as legitimate employers. The creation of an alternative regulation, which was, moreover, based on different grounds, was thus regarded as a real threat and the strategy was therefore damage control. A report was ordered and seminars were held with the interested parties (Malmberg, 2009). The industry's concern about the risk of damage to the Swedish (staffing) model was, however, not shared by the other camps, not even in areas where there should have been consensus: the fact that in Sweden "German" derogation would primarily impact non-organised companies and should therefore not be used. On the employee side, the adoption of the Directive seems mainly to have been a question of solidarity vis-à-vis employees in the former eastern bloc countries.

\subsubsection{Commission of Inquiry into the Implementation}

As is always the case, a Commission of Inquiry was initiated when the Directive was going to be implemented in Sweden, and Professor Birgitta Nyström was appointed to lead it. A reference group with representatives from the social partners was set up to assist the Inquiry. After a year and a 
half and two extensions, a comprehensive proposal was submitted in the normal Swedish legislative tradition regarding the supplementary legislation that was deemed necessary, here in the shape of a new Act on Temporary Agency Work (the Agency Work Act).

However, the work of the Inquiry was not uncomplicated, partly because of the issues at stake, partly also because of the attitude of certain central parties towards the staffing industry. As regards the former, it concerned, amongst other things, the status of the existing collective agreements but also workers posted to Sweden and their need for reinforced protection and the possibility to take industrial action to influence this. In the wake of the Laval judgement, this particular nut was not an easy one to crack and there was widespread disagreement regarding whether there were formal grounds to regulate the issue, and whether it should be done at all, because a complex Swedish act on posted workers risked becoming ever more complex and would lead to disputes with unexpected consequences for the Swedish labour-market model.

As regards the latter complication in the work of the Inquiry (the attitude of a central party), a representative from the reference group put forward the view that agency work should only be allowed to meet temporary needs in the user undertakings. When the Inquiry Chair declined to agree to this but instead claimed that the issue lay outside the remit of the Inquiry, the same party requested instead that the terms of reference for the Inquiry be supplemented, albeit still without success. In a letter to the Minister for Employment, the grounds for the request were stated as being a question of the Swedish model "being in essence based on workers actually physically working at the company or authority where they are employed." Therefore the request entailed the introduction of a similar restriction in the shape of a semi-compulsory rule which would transfer the staffing issue from the employer's prerogative to the negotiation table. Not unexpectedly the staffing industry perceived this as a frontal attack, and collective bargaining, which had been paralleling this, had to be postponed.

Moreover, a deficient translation has contributed to certain issues keeling over in the Swedish discussion on the implementation of the Directive. This applies above all to the exemplification of the general interest and the grounds for restrictions and prohibitions. In the Swedish version of the Directive, the word "agency" has been omitted - in all other language ver- 
sions the first example is specified as "the protection of agency workers". The focus has thus shifted from the group the Directive is supposed to protect, the agency workers, and instead is on all the other groups in the labour market. However, even the provision on access to the amenities or collective facilities, a novelty, but with a limited practical impact in Sweden, has been incorrectly translated in the Swedish version. Here the word "benefits" has crept into the text, with no basis in the other language versions and initially risked giving this provision an entirely different scope than intended. However, an adjustment has been made here.

\subsubsection{A Review of Restrictions and Prohibitions}

The trickiest problem for the staffing industry has been the significance and status of Article 4, however, and this is in fact still the case (see the following section). Even if the examples of restrictions on the use of agency work, which were submitted to the Ministry of Employment about a month after the Directive was adopted, were also processed and examined by the Inquiry, it made no effort to make its own review. This was regrettable for two reasons. Firstly, because the period during which agency work was banned led to many different applications which still curtail the possibility of using agency work in different ways. Secondly, because a review by the Inquiry would have illustrated the need for a blocking rule to ensure that unjustified restrictions were not introduced in the new Agency Work Act. The view of the Inquiry Chair, however, was that it was unclear whether the provision was of both material and procedural significance. In any case, she did not wish to pre-empt the European Commission's review of the implementation of the Directive in the Member States. The Government subsequently agreed.

The industry would have preferred a blocking rule to be included in the new Agency Work Act, both to make it easier to question current restrictions but also to prevent the emergence of new ones. The industry also wanted the same clarity concerning the right to a reasonable level of recompense for services rendered to the user undertakings for the assignment, recruitment and training of temporary agency workers, which is also included in the Directive. Here, however, the wording in the preparatory work was better with respect to Article 4 . 
Regarding the restrictions subjected to review by the Inquiry, two gained support. The first concerned the quarantine rule contained in the Act on Private Employment Services to protect employers against workers obtaining better conditions by joining a staffing agency, a rule that was important primarily for dominant employers like the County Councils (i.e. monopsonies). This rule was abolished due to the Directive. The second restriction concerned the right to unemployment benefits, which had not been fully recognised for agency workers in part-time or fixed-term employment. The Inquiry Chair noted that the law was now clear but that the application of the unemployment insurance funds had not kept up with developments. Both restrictions have affected the conditions for the use of agency work in that they have limited the supply of candidates by reducing their desire to seek employment with staffing agencies.

As concerns restrictions and prohibitions in collective agreements, the review was left up to the social partners. A systematic inventory with subsequent analysis was conducted by the Confederation of Swedish Enterprise. In contrast, according to the $\mathrm{LO}$ and the TCO, there were no unjustifiable restrictions, although they did not specify this in more detail. The other organisations said that there were no restrictions in the areas covered by their collective agreements.

The Inquiry Chair submitted her report in January 2011, and that was the end of it. Following the general election in 2010, the Alliance parties constituted a minority government and they encountered opposition above all in the Committee on the Labour Market. It proved difficult to steer the implementation of the Directive further through the legislative process.

\subsubsection{Complaints to the European Commission}

For businesses, a lack of predictability is one of the most difficult problems to deal with, which is why the industry brought this up when no progress was made during the remainder of 2011 or the first half of 2012. This was done by repeatedly contacting the Government Offices and also by submitting an initial complaint to the European Commission in March 2012, at the request of officials at the European Commission following a meeting with them in Brussels during the same period of time. Thereafter, the Commission sent a letter of formal notice to the Kingdom of Sweden 
about the lack of implementation and information about this process. Until then, the Council on Legislation, to which proposed bills are referred before being submitted to the Parliament, had been the industry's sole source of information regarding the constantly postponed plans of the Government Offices concerning a new Agency Work Act.

It was only after further pressure from the European Commission, this time as a reasoned opinion dated 22nd June 2012, that the Alliance Government reached an agreement with the Green Party regarding implementation. However, a residual matter remained after the agreement had been concluded: a second Commission of Inquiry, but this time to examine whether agency workers are used to evade rules on employment protection. There had been lively discussions on alleged abuse, particularly in Parliament and the media. When the very existence of the industry was being discussed, further aspects were thus added to the course of events.

Two years later, Professor Eskil Wadensjö, the Inquiry Chair, stated that the use of agency workers in situations where workers, who had previously been made redundant, had a priority right to re-employment occurred extremely rarely (SOU 2014:55). Instead, agency work was used to manage variations and resolve organisational problems. It was also presumed that the rules on the use of agency workers and priority rights for re-employment, which had been introduced in collective agreements in the LO sector in 2010, had had some impact, even if the Inquiry Chair also noted that these had basically never been applied. Paradoxically, the issue of the introduction of restrictions on the use of agency workers came up during the collective bargaining round in 2010, i.e. at the same time as the other Inquiry was reviewing the very same kind of restrictions.

On 5th July 2012, a proposed bill was referred to the Council on Legislation, which had been first announced almost a year earlier. In September, the Government decided on a bill and at the end of November it was adopted by Parliament to enter into force at the New Year, in other words over a year late.

When the industry noted that the bill had not provided Article 4 with a material content either, it decided to follow up with a further complaint in November 2012. During the legislative process, the strategy had been to try to influence the end product, but now the tactics were changed to try to get 
the issue reviewed by a court, either through infringement proceedings or a lawsuit, which would ultimately determine the scope of the provision.

The complaint concerned the impact of not having a material prohibition rule to invoke against restrictions and prohibitions on the use of agency work. Two additional complaints illustrating the problem were submitted in 2013. One concerned the quarantine rule that had been included in the Act on Private Employment Services and, despite having been abolished, was still used to a much greater extent and on more categories of workers than had applied according to the rescinded statutory rule. The second concerned the absolute obligation to negotiate before using agency work in Section 38(2) of the Act on Co-determination, which not only disfavours the industry unjustifiably but which has also proved to serve as a platform for agreements at primarily the local level regarding all types of restrictions on the use of agency work. In this context, the industry easily becomes small change in exchange for something else.

\subsubsection{The Legal Development via Court Proceedings}

Even if the European Commission at an earlier stage had recognised the inexpedient way in which Sweden had handled the Agency Work Directive, the continuation did not seem to be straightforward for the Commission. Everyone who has followed the process of the implementation of the Directive closely has been able to note the ambivalent stance of the Commission vis-à-vis Article 4, where different Directorates have established different perspectives on the question. Formally, this has manifested itself in the very late arrival of the implementation report and in the contradictory stance in the Finnish case C-533/13, which is being processed by the Court of Justice of the European Union (CJEU). Nor has a reply to the Swedish Staffing Agencies' complaints been submitted; instead the Commission has notified the Federation that it is awaiting the implementation report and the legal developments.

Preparations were made to have the issue reviewed by a Swedish court, with the possibility of referring the case to Luxemburg. But before this was put into effect, the Finnish Labour Court decided in October 2013 to request a preliminary ruling on a dispute about the scope of the Agency Work Directive. The Finnish case concerns restrictions in collective 
agreements on the use of agency work, both grounds for the use of agency work and the length of assignments, and the questions posed concern Article 4 and its possible direct effect, the admissibility of the current collective-agreement provisions and the role of national courts in realising the goals of the Directive.

The Advocate-General recently submitted his opinion, which is both pleasing and gives rise to concern. It is pleasing in that Article 4 is presented as a material prohibition against unjustified restrictions, valid vis-à-vis both statutory rules and collective agreements. Moreover, the dual goals of the Directive and the role of the industry in ensuring a well-functioning labour market are recognised. It gives rise to concern because the restrictions in question are considered justified since direct employment is always preferable, something which seems, however, to build on the assumption that employment in the staffing industry is always fixed-term, i.e. temporary. Moreover, the opinion claims that this type of work is not suitable in all circumstances, in particular when the need for labour is permanent. It is also noted that the Member States have been given a great deal of discretion when assessing the situations where the use of agency work is justifiable. At the same time, it is noted that sectoral bans or quotas cannot be justified as a measure to prevent abuse (a general interest) without any other objective goal.

It is worth noting that the Court decided to hear the case in the Grand Chamber, i.e. with the maximum number of 15 presiding judges. One lawyer has described this as preparing to "drop a bomb". The question arises as to what might constitute such a bomb. The questions in the plenary mainly concerned the legal basis of the Directive and its importance for the interpretation of the Directive. Certain parties have claimed that it excludes the possibility of interpreting Article 4 as a prohibition of unjustified restrictions. As the Advocate-General also points out in his opinion, this line of reasoning would lead to an invalidation of the Article even though he himself does not accept this, as, in his view, the Directive has, and can have, a dual objective. The threat of invalidation is naturally terrible since it would jeopardise many of the aspirations of the industry. Perhaps there is still reason to expect the unexpected. In the meantime, however, a case regarding the admissibility of quarantine rules in public procurement has sailed up on the Swedish horizon. Perhaps taking this to the CJEU would provide a more nuanced picture in the long term. 


\subsection{Threats and Opportunities}

An accepted standpoint is that it is above all the absence of two features in the Swedish labour market model that makes the implementation of EU Directives in the area of the labour market complicated: generally applicable collective agreements and minimum-wage legislation. It has been presumed that an exemption was granted for the non-comprehensive nature of Swedish collective agreements when Sweden joined the Union, but CJEU case law has stood this on its head. Instead, the need for supplementary legislation has come to the fore, but the consequences are still difficult to predict. One simple conclusion is that this is a clash of different legal traditions. This is particularly true of the Agency Work Directive. Below is a description of certain threats and opportunities that have been identified.

The implementation has entailed a whiff of something exotic in the Swedish model and there is a risk that this will upset the balance in the model in the long term. Firstly, through the Swedish Agency Work Act, the staffing industry has been given an alternative to regulation through collective agreements, affecting both conditions and wages. Secondly, because the principle of equal treatment points at what applies in the user undertaking, which normally still has a collective agreement as a basis, the user undertaking's collective agreement is given an applicability outside the circle of the initiated: a type of indirect general applicability. Thirdly, the dependence of the compliance mechanism on the established partners is revealed. Outside the unionised segment of the labour market, the individual is once again alone in invoking his/her rights. Fourthly, if the Advocate-General's opinion stands, the boundaries for the social partners' right to collective bargaining will be defined further.

Even supplementary legislation, the Agency Work Act, is difficult in many parts. Exemptions from equal treatment are made for the Swedish model, i.e. regulation through collective agreements can replace it. At the same time, equal treatment in the Directive constitutes a yardstick and potentially opens the way for attacks on collective agreements which are perceived as not living up to this standard. And, since the principle of equal treatment does not include more than basic working and employment conditions, there is a risk that conditions in the same areas covered by collective agreements, but which have been introduced through give 
and take in other areas, will also be torn up, the consequence being that the original counter offering is re-evaluated. This in turn creates an imbalance in the bargaining relationship and in the long term negotiations may fail. One example of this is holiday leave, where there are distinct differences between the public and private sectors. The fact is the public sector is where discussions regarding the level of the social partners' agreements have arisen, even if they have not yet led to disputes or litigation.

Certain parts of the Agency Work Act also apply to posted agency workers. If equal treatment is preferable to the hard core of the Posting of Workers Act, however, action from the labour organisations is required: the so-called reinforced protection. This means that Swedish trade unions can, under the threat of industrial action, demand the equal treatment of agency workers posted to Sweden unless the foreign staffing agency can show that it provides the corresponding level. This is seemingly a less cumbersome process than making equal treatment applicable to all. At the same time, there are labour organisations that refrain from using that right since it enables them to point out to the user undertaking that the foreign staffing agency lacks a Swedish collective agreement. This is an unanticipated but probably effective way to limit the supply of labour.

Regarding the awaited ruling from the CJEU, one decisive question is the extent to which other parties are allowed to determine the conditions for the hiring of labour. This issue has a negative impact on the staffing industry in two ways. Firstly, it has a negative impact on its development and secondly, its existence. These aspects are illustrated in the said order in the figures below.

As has already been discussed and as is shown in box D in Figure 1, the Swedish staffing industry has been able to offer its workers long employment contracts because these companies have been allowed to take on assignments on a commercial basis, i.e. long-term business (D). That type of quality strategy is, however, difficult to maintain if the assignments with the user undertaking are limited in time or in any other way that is not related to the preconditions or needs of the user undertaking. In countries with such restrictions, the staffing industry is an undeveloped temporary work sector with many short employment contracts as a consequence (A). In Sweden, such a development would lead to the current quality strategy being replaced with a quantity strategy. As is also illus- 
trated, other combinations are difficult to manage for trade unions (B) and agencies (C) respectively.

Figure 1

\begin{tabular}{|c|c|c|c|}
\hline \multirow[b]{3}{*}{ Employment } & & \multicolumn{2}{|c|}{ Business Strategy } \\
\hline & & Short Term & Long Term \\
\hline & $\begin{array}{l}\text { Short } \\
\text { Term }\end{array}$ & $\begin{array}{l}\text { A. } \\
\text { Short business contracts } \\
\text { Short employment contracts } \\
\text { = Quantity strategy }\end{array}$ & $\begin{array}{l}\text { B. } \\
\text { Long business contracts } \\
\text { Short employment contracts } \\
\text { = Difficult for TUs }\end{array}$ \\
\hline strategy & $\begin{array}{l}\text { Long } \\
\text { Term }\end{array}$ & $\begin{array}{l}\text { C. } \\
\text { Short business contracts } \\
\text { Long employment contracts } \\
\text { = Difficult for agencies }\end{array}$ & $\begin{array}{l}\text { D. } \\
\text { Long business contracts } \\
\text { Long employment contracts } \\
\text { = Quality strategy }\end{array}$ \\
\hline
\end{tabular}

An equally serious threat, which is also a consequence of others regulating the use of agency work, is that the staffing industry as a joint force for companies whose mission is agency work may be dissolved. This is illustrated in Figure 2

\section{Figure 2}

\begin{tabular}{|c|l|l|}
\hline \multicolumn{1}{|c|}{ External } & \multicolumn{2}{c|}{ Regulation } \\
\cline { 2 - 3 } & $\begin{array}{l}\text { A. } \\
\text { Other actors organise } \\
\text { Other actors regulate } \\
=\text { No staffing industry }\end{array}$ & $\begin{array}{l}\text { B. } \\
\text { Other actors organise } \\
\text { Self-regulation }\end{array}$ \\
\hline Organisation & $\begin{array}{l}\text { C. } \\
\text { Self-organisation } \\
\text { Other actors regulate }\end{array}$ & $\begin{array}{l}\text { D. } \\
\text { Self-organisation } \\
\text { Self-regulation } \\
\text { = Bona fide staffing industry }\end{array}$ \\
\hline
\end{tabular}


In order to prevent the introduction of restrictions, more staffing agencies will move towards those sectors where their business conditions are determined, going from $\mathrm{D}$ to $\mathrm{A}$. When the companies in the industry have spread out, there will be no organisation with clear responsibility for developments or for monitoring them. To sum up, this is when the staffing industry will leave the Swedish labour market model.

\subsection{Concluding Remarks}

A well-functioning labour market is largely a critical issue for Europe. Apart from the fact that companies and authorities will have trouble developing if the mismatch between the supply of and demand for labour becomes too great, it will create tensions in society and poor conditions under which to finance existing welfare models. Seen as a part of the labour force, the staffing industry is not substantial in any of the Member States. Nonetheless, if adequately regulated, it can help more companies to develop and more workers to find a place for themselves in the labour market.

The trend towards more specialised operations has been ongoing for a long period of time and the need for different services concerning the supply of talent and skills is the consequence. For labour organisations, agency work should, moreover, be the most attractive alternative when companies decide to outsource their operations. Conditions are either regulated by collective agreements or the Agency Work Act. The corresponding option does not exist for outsourcing, and even less so for offshoring, alternatives which take the labour force further and further away from trade-union control.

In Sweden, the staffing industry is resilient and it will probably also survive the challenges described above in one shape or other. Presumably there are even stronger forces that risk having a greater negative impact on the Swedish labour market model than a clash between legal traditions. The decline in the level of affiliation on the labour side is one such issue that risks undermining the situation, creating a need for parallel solutions. The difference in levels of affiliation between the social partners in the private sector has increased to $16 \%$ since the 1990s (Kjellberg 2014). This is naturally a problem in itself. It becomes, however, particularly visible in 
the staffing industry where there are many young people. The level of affiliation in the 17-29 age group is now at an average level of $47 \%$. In other words, it is in the staffing industry that this gap is exposed. The question is whether regulatory instruments like the Agency Work Directive will contribute to widening it further. The risk is then that it will be filled with something else as there are always strategies and solutions, and alternatives will always emerge. The question is, however, whether they will be equally palatable.

\subsection{Bibliography}

Anders Johnson (2010). Hyrt går hem: historien om den svenska bemanningsbranschen. Stockholm: Informationsförlaget.

Anders Kjellberg (2014). Kollektivavtalens täckningsgrad samt organisationsgraden hos arbetsgivarförbund och fackförbund. Lund: Sociologiska institutionen, Lunds universitet.

Jonas Malmberg (2009). Hur ska bemanningsdirektivet genomföras i Sverige? Uppsala: Juridiska fakulteten, Uppsala universitet.

SOU (2001). 2011:5 Bemanningsdirektivets genomförande i Sverige. Stockholm:

Fritzes offentliga publikationer.

SOU (2014). 2014:55 Inhyrning och företrädesrätt till återanställning. Stockholm:

Fritzes offentliga publikationer.

www.bemanningsforetagen.se

www.tryggbemanning.se 



\section{The Role of the Implementation Committee in Denmark with focus on the Temporary Agency Work Directive Ane}

Kristine Lorentzen ${ }^{23}$

8.1 Basis for the implementation of Directives in the field of labour law in Denmark

\subsubsection{The legislator's wish to implement Directives within the framework of the Danish collective- bargaining system}

The Maastricht Treaty, which came into force on 1st November 1993, made it possible - via the special social protocol for the EU countries, including Denmark - to adopt labour-law directives with a qualified majority. Subsequently, the social protocol was integrated into the TEU. Early on, the European Court of Justice accepted labour-market agreements as instruments of implementation; however, each state must at all times be able to secure the desired outcomes of the Directive. 
While it has been agreed that the EU can adopt rules to an increasing extent in the field of labour law, it has been important for Denmark to maintain its collective-bargaining system as the hub for determining wages and working conditions.

This is reflected in adoptions by Folketinget, the Danish Parliament, back in 1993, as well as in the method which has been and is still used for the implementation of labour-law directives in Denmark.

The basis for the implementation of labour-market directives in Denmark was also incumbent on Folketinget's motion on the order of business of 30th November 1993, when Folketinget gave its support to maintaining the Danish model in EU cooperation, thereby allowing the social partners in Denmark to carry out implementation within the framework of the collective-bargaining system, including the use of collective agreements or other labour-market agreements.

The text adopted in 1993 was as follows:

"Folketinget calls upon the government to work actively to implement the social dimension with a view to creating a socially balanced community.

Folketinget finds that in EU cooperation in the field of the labour market it is in Denmark's interest to maintain the Danish model, based primarily on collective bargaining, not legislation, and calls upon the government to cooperate with the social partners on processing motions for Community Directives and, in labour-market discussions in the EU, to work consistently to ensure.

- that Community measures allow latitude for national traditions and decisions;

- that the social partners in Denmark be given the possibility to implement such measures within the framework of the collective bargaining system, including collective agreements and/or other labour market agreements."

\subsubsection{LO/DA agreement on a Directive-implementation procedure in the field of labour law}

This approach has been further developed in Denmark, also on the basis of encouragement from LO (the Danish Confederation of Trade Unions) and DA (the Confederation of Danish Employers). In 1996, LO and DA concluded an agreement for an implementation procedure in connection 
with the implementation of EU Directives, cf. the LO/DA agreement of 1st July 1996.

The following was written about the basis for the LO/DA agreement:

\begin{abstract}
"It is essential for LO and DA that the adaptation on the Danish labour market to the decisions made in the EU is carried out in a way that allows the social partners to continue the self-administration which has been the standard of the Danish labour market throughout this century. In particular, it is deemed important to maintain the industrial-disputes system as well as the respect for agreements concluded locally by the parties to collective agreements. Against this background and with a view to ensuring adequate implementation of EU Directives via agreements, DA and LO have adopted this implementation procedure...."
\end{abstract}

The procedural recommendation to the Minister for Employment states that as soon as a Directive has been adopted in the area of labour policy, a period should be granted in which the possibilities of implementing the Directive via the collective-agreement system are reviewed, without introducing competing legislative bills at the same time.

It is also recommended that, after negotiations between the social partners have been completed, the Ministry of Employment and the umbrella organisations of the social partners take stock of the possible scope of implementation through collective agreements. Based on this, it should be decided which supplementary measures are required to meet the requirements concerning timely and adequate implementation of the Directive. Furthermore, the agreement specifies the shared view of LO and DA, i.e. that in supplementary implementation it should be ensured that concluded agreements on implementation are not amended, provided that these agreements comply with the minimum requirements of the Directive.

LO and DA propose that a committee of representatives of the social partners be established as an advisory body to the Minister in the implementation process to ensure that the above-mentioned considerations are taken. 


\subsubsection{Establishment of the Implementation Committee in Denmark}

Since 1993 and in connection with the work on implementation of Directives in the field of labour law in subsequent years, a practice has developed in Denmark which is in line with the wishes expressed in the LO/DA agreement as regards the actual implementation process as well as with the wish to have collective agreements respected as the primary implementation instrument.

However, the government wanted the practice that had been developed to be put into a more rigid framework, so it established the so-called Implementation Committee in December 1999. The Committee was established by the Minister for Employment as an advisory body for the implementation of labour-market Directives. The Implementation Committee was established with the participation of representatives of the social partners from the public and private sectors. The terms of reference for the Committee consisted of a reference to a decision of Folketinget in 1993 to carry out implementation within the framework of the collectivebargaining system, as well as the wish to ensure appropriate and full implementation of EU Directives. The terms of reference describe the process to be formalised in connection with the work of the Committee.

A process has been established in the Implementation Committee according to which the social partners, after adoption of a directive, inform the Ministry of whether the Committee supports full or partial implementation of the Directive through collective agreements. A meeting of the Committee is to be held to organise the implementation procedure, including agreements on joint implementation deadlines. At this stage in the process, the social partners are usually given a time frame within which to implement the Directive through collective agreements, while keeping the Committee regularly informed on the implementation status at the same time. Naturally, this does not apply in cases where the Directive does not allow any possibility of implementation through labour-market agreements. In such instances, the Implementation Committee immediately starts to prepare implementation through legislation. Specifically, this is often done whereby the Implementation Committee establishes a working group under the Implementation Committee with the participation of the 
social partners, so that a specific proposal for implementation through legislation may be prepared.

In situations where implementation through a collective agreement is possible, supplementary legislation will usually have to be introduced to ensure that all wage-earners, i.e. groups not comprised by implementation through collective agreements, are granted the rights of the Directive through legislation. In Denmark, collective agreements apply only to the parties which enter into the agreements, typically through membership of relevant employers' association or via a trade-union adoption agreement.

Once the social partners have carried out the implementation possible through labour-market agreements, or when otherwise deemed necessary to start up the process of supplementary implementation through legislation, the difficult part of the work of the Committee or working group begins, which is to transpose the provisions of the Directive into legislation while respecting the agreements made between the social partners. Incidentally, it is assumed that the implementation carried out through labour-market agreements is not affected by the supplementary implementation through legislation, always provided that the implementation through labour-market agreements complies with the provisions of the Directive. In addition, work is done to ensure that the implementation through legislation adheres closely to the labour-market agreements entered into by the social partners to implement the Directive. This implementation process applies not only to the implementation of Directives in Denmark. The Implementation Committee plays a correspondingly large role in the now rather frequent situations in which decisions by the European Court of Justice necessitate changes to Danish collective agreements and/or legislation. For example, the Implementation Committee played a decisive role in the change of practice and legislation resulting from the European Court of Justice decision in the Lavel case, C-341/05. Similarly, the Implementation Committee carried out work on a proposal to change the provisions of the Danish Salaried Employees Act on severance pay for employees with high seniority, resulting from the European Court of Justice decision in the Ole Andersen case, C-499/08. A proposal has now been put forward to amend the Act on the basis of a joint proposal of the Implementation Committee from LO and DA. 
Summing up, the work of the Implementation Committee is characterised by mutual understanding of the principles of the Danish model, as well as the basic assumption that labour-law rules should be regulated through collective agreements. However, the work of the Implementation Committee also reflects the fact that, in areas regulated by the EU, the government has an independent obligation to ensure adequate implementation.

Seen from the point of view of the LO and probably from the point of view of several parties in the Danish labour market, it is essential that the implementation of Directives in Denmark is strongly rooted in collective agreements - both as the primary implementation instrument and in relation to the legislation that covers the remaining groups. This could also be expressed by saying that the Danish model basically does not support the concept of extensive labour-law regulation through legislation; however, when such legislation is necessary or appropriate, e.g. due to workers crossing borders or in relation to disadvantaged groups, it is essential that the implementation models of the social partners be used as a basis for laying down rules.

\subsection{The Temporary Agency Work Directive as a concrete example of Directive implementation in Denmark}

A description of the overall principles for implementation of EU Directives in the field of labour law in Denmark is provided above. However, it should be added that there has been some variation from one Directive to the next as regards the specific mode of implementation and the significance of collective agreements in this regard. This is particularly linked to the fact that some Directives, especially from before 2000, do not allow for actual implementation through labour market agreements. In some cases, this is linked to the fact that the obligations resulting from the Directive are not suitable for implementation through collective agreements, or the Directive may not formally allow implementation through collective agreements. As regards some implementation of Directives in Denmark through legislation, subsequent statutory changes have, however, given 
formal first priority to provisions in collective agreements that are on a par with the Directive.

Subsequent Directives have to a greater extent been worded so as to allow the social partners and collective agreements to be more of a regular fixture as regards implementation.

\subsubsection{Implementation of a semi-dispositive Directive - the Temporary Agency Work Directive}

The Temporary Agency Work Directive was adopted on 19th November 2008, with an implementation deadline of 5th December 2011. The Directive took a long time to be adopted; back in the spring of 2000, the social partners at European level stated that they wanted to start up an agreement process, but this was abandoned in 2001, following which the Commission presented its first proposal in 2002.

The purpose of the Directive is to protect agency workers; to improve the quality of agency work by ensuring that the principle of equal treatment also applies to agency workers; to recognise agencies as employers; and to establish a suitable framework for agency workers with a view to creating employment and flexible types of work.

The Directive was not implemented in Denmark until an Act was adopted which was to come into effect on 1st July 2013, i.e. more than eighteen months after the implementation deadline. The implementation of this Directive was rather difficult in Denmark, which is also reflected in the fact that implementation occurred so much later. Naturally, there may be different assessments of the reason why, but some possible reasons will be outlined in the following.

As mentioned above, the Temporary Agency Work Directive is a socalled semi-dispositive Directive, i.e. a Directive which in certain respects and under certain conditions allows downward deviations from the Directive in collective agreements. Specifically, it is possible to deviate from the bearing principle of equal treatment in different situations listed in the Directive. One of these situations is specified in Article 5(3) of the Directive:

\footnotetext{
"Member States may, after consulting the social partners, give them, at the appropriate level and subject to the conditions laid down by the Member States, the option of upholding or concluding collective agreements which,
} 
while respecting the overall protection of temporary agency workers, may establish arrangements concerning the working and employment conditions of temporary agency workers which may differ from those referred to in paragraph 1."

In Denmark, there has been intense focus in recent years on the use of temp agencies, particularly in areas covered by LO. In many areas, the use of agency workers is seen by trade unions as a way for companies to avoid general and local collective agreements. This approach is still widespread for the most part, but it deserves mentioning that many agencies today are covered by collective agreements, just as agency workers may be covered by the collective agreement in force at the user enterprise. However, the regulation of agency workers in collective agreements is characterised by great variation and relatively widespread legal uncertainty. Basically, as regards employees of Danish temp agencies, both the agency worker and the agency may interrupt the person's employment without notice, unless otherwise agreed in a collective or individual agreement. However, even agency workers covered by a collective agreement rarely achieve longer termination notices, since this is not provided for in the agreement, or since the agency workers do not attain the seniority required on the job. In Denmark, agency work is thus characterised by short-term employment and a poor guarantee of longer term employment.

Some labour market agreements - such as the Collective Agreement of the Manufacturing Industry - are basically not agreements directed at agency workers. Even so, the mentioned agreement contains a few provisions concerning agency workers and includes a principle of equal treatment with the regular employees of the user enterprise.

The entry attached to the Manufacturing Industry Agreement specifies that the agreement "applies to employees provided by temp agencies to work at a member enterprise within the trade-union areas covered by LO for the time period of the agency contract. The Manufacturing Industry Agreement includes local agreements and customs which apply to the work functions carried out by the agency worker."

Similar provisions apply to a number of collective agreements in the construction industry, although the principle has not necessarily been entered in the agreement, but follows from the nature of the agreement as sector agreements. This arrangement means that user enterprises covered 
by agreements are obliged to verify that agency workers receive wages, etc., in accordance with the collective agreement and any local agreements in force. In these areas, the principle of equal treatment corresponds in many ways to the principles of equal treatment contained in the Temporary Agency Work Directive. However, a number of other areas covered by labour-market agreements in Denmark have a somewhat different arrangement. Most Danish temp agencies are now covered by collective agreements which specifically regulate the wages and employment conditions of agency workers. One case in point would be the National Agreement on Agency Workers between the Danish Chamber of Commerce and the $3 \mathrm{~F}$ trade union; this agreement defines a number of conditions which apply regardless of the conditions in the user enterprise. The agreement applies to the issue of termination notices, for example. According to the collective agreement, a person is only entitled to a termination notice if the person has had more than 1,924 hours of paid employment within a period of 15 months, following which the only notice, the maximum, is 14 days' notice by the employer. The agreement also contains separate provisions on pensions, holiday leave, pay on national holidays, days off in lieu of holidays, wages during illness, parental leave, etc.

On the other hand, the actual wages and working hours are regulated so that the same conditions apply as those specified in the relevant collective agreement covering the user enterprise. If the user enterprise is not covered by a collective agreement, specific, selected, leading collective agreements in 3F's area will apply to wages and working hours.

Furthermore, it is worth noting that many collective agreements in force in Denmark (and applicable to user enterprises) do not contain any provisions on the use of agency workers, or provide no clarity as to any obligations involved when using agency workers.

This mixed picture of conditions under collective agreements for agency workers in Denmark forms the basis for the upcoming work on the implementation of the Temporary Agency Work Directive in Denmark.

After the Directive had been adopted, the Implementation Committee decided to let the social partners conclude agreements or present models for implementation through collective agreements. After about two years, however, it became clear that no agreements had been concluded and no proposals for models involving the social partners were submitted, which 
meant that negotiations continued under the auspices of the Implementation Committee.

Why was it difficult to reach a common understanding?

Firstly, it turned out that there was considerable disagreement on whether to utilise the possibilities offered by the Directive when it came to deviating from the equal treatment principle laid down. Naturally, the parties focused on the opt-out possibility contained in Article 5(3) on the right to deviate in collective agreements; however, the labour viewpoint was that deviation from equal-treatment principles through collective agreement could only become relevant if the parties to the individual agreements could agree on this. Many trade unions were and are of the view that a number of collective agreements are not really suited to handle agency-worker situations and that the equal treatment principle of the Temporary Agency Work Directive was the most suitable solution, unless other arrangements could be negotiated within the field of the individual collective agreement. Conversely, the employer viewpoint - stated most clearly by some temp agencies which are members of employer organisations - expressed dissatisfaction with precisely this principle of the Directive, the equal treatment principle. These temp agencies did not want to have a complete equal-treatment principle imposed on them, as specified in the provisions of the Temporary Agency Work Directive.

It is worth mentioning that, as described, there was and is considerable legal uncertainty in Denmark about the legal position of agency workers - in relation to legislation and labour-market agreements - to which must be added the complication which comes from the fact that an agency-worker situation is tripartite, so it does not fit into the usual agreement model between an employer on the one hand and a wage-earner on the other.

Finally, it should be mentioned that the labour viewpoint focuses on the growing use of foreign agency workers in Denmark and the social dumping associated with this.

Undoubtedly, these matters played a role in protracting the process in light of the difficult job of finding a common solution. 


\subsubsection{The Danish Temporary Agency Workers Act}

As the situation developed, the summer of 2011 saw relatively high consensus on the Implementation Committee about the provisions for implementing all the provisions of the Directive, apart from the rather significant possibility for the national state to introduce provisions on access deviating from the equal-treatment principle of the Directive in collective agreements. However, the deadlocked situation did not stop the social partners in the manufacturing industry from concluding an implementation agreement in the Manufacturing Industry Collective Agreement. It is worth noting, however, that, as mentioned above, the Manufacturing industry Agreement already included a clause on agency workers with an equal-treatment principle stipulated in writing.

The implementation agreement between the social partners in the manufacturing industry largely states that the existing equal-treatment principle of the collective agreement would be upheld, with some necessary adjustments resulting from the Directive.

In other parts of the labour market where an equal-treatment principle does not apply or only applies to a limited extent, there was, however, great resistance from employers to introducing a general equal-treatment principle, so there was no basis for a common solution, which was also the case in connection with the collective bargaining on the private labour market in the spring of 2012. Since no solution had been found by early 2013, the social partners in the manufacturing industry approached LO, DA and the Minister for Employment and proposed a solution model which ended up becoming the model used in the Danish Implementation Act.

In Denmark, the solution has thus become implemented quite close to the Directive with access to deviating from the equal-treatment principle of the Act in collective agreements. The Danish Temporary Agency Workers Act has the following provision in Section 3(5):

\footnotetext{
"Subsections 1-4 [including the equal treatment principle] shall not apply if the temporary worker agency is covered by or has acceded to a collective agreement which has been concluded by the most representative social partners in Denmark and which applies to all of the Danish area, whereby the general protection of agency workers is respected."
} 
Overall, the model has the advantage of recognising the Danish labourmarket agreements and includes a guideline for decent wages and conditions of employment, thereby also ensuring that agency work is carried out based on Danish conditions. This largely prevents the occurrence of social dumping when using foreign workers.

On the other hand, it could be argued that agency workers are a particularly vulnerable group and constitute a labour resource that could undermine the significance of the collective agreements in force in user enterprises and undermine the negotiating position of employees of these enterprises, which is why special agreements are required. It should be added that the overall problem, which is that many Danish labour-market agreements are not suitable for handling agency workers, and the fact that the model does not ensure that local agreements in user enterprises are applied to agency workers means that in reality there may be considerable wage differences between agency workers and comparable employees of user enterprises.

In summary it may be argued that, as regards the implementation of the Temporary Agency Workers Directive, no common understanding was reached between the social partners, even if the model is based on applicable collective agreements. Danish collective agreements handle the use of agency workers quite differently, which is why genuine protection for agency workers varies greatly from one collective agreement to the next. Finally, the process for the implementation of the Temporary Agency Workers Directive was obviously not ideal, given that the Danish Temporary Agency Workers Act was not implemented until eighteen months after the implementation deadline. 


\section{Finnish TSN-YTN Case with Some National, Nordic and European Reflections}

Jari Hellsten ${ }^{24}$

\subsection{Introduction}

The Court of Justice of the European Union (CJEU) handed down its ruling in the joined Finnish Cases C-512/11 TSN and C-513/11 YTN on 13th February 2014. The two Finnish trade unions, TSN (trade union in the health and social sector, "TSN") and YTN (senior officials' trade union, "YTN"), argued the cases before the national Labour Court. Both cases concerned the right to remuneration during a new maternity leave under the respective national collective agreements. The female workers concerned switched over to the new maternity leave from unpaid parental leave and their employers refused to pay maternity remuneration included in the respective collective agreements. The clauses concerning this remuneration in both collective agreements had been interpreted and applied by the employers to mean that the mother had to have returned to work before starting on the new maternity leave in order to be entitled to the maternity-leaver remuneration. The CJEU found such a condition incompatible with the Parental Leave Directive 96/34. Thus, the trade unions won their cases, which also merit being discussed from the point of view of social dialogue and collective agreements in national, Nordic and

${ }^{24}$ Lawyer at SAK, the Central Organisation of Finnish Trade Unions. 
European contexts. In so doing, the interaction between the law and collective agreements is accordingly important. In addition, the elastic nature of the preliminary ruling procedure and the interpretative effect of EU law is also found in these cases.

\subsection{Essence of the collective agreements and national proceedings}

The sectorial collective agreements concerned those for salaried employees in the healthcare services sector (the TSN case) and for senior officials in the technology industries (the YTN case) have since the 1990s granted certain maternity-leave remuneration. For salaried employees, this covers a period of 72 weekdays with full salary, provided that the mother has been employed for at least three consecutive months before taking the leave. For the senior officials concerned, the clause in the collective agreement stipulates as follows: "During the maternity leave, full pay is paid for three months, provided that the [mother's] employment relationship has continued without interruption for at least six months before the confinement."

In both cases the mothers became entitled to maternity leave during an unpaid parental education/childcare leave. Their employers refused to pay any maternity-leave remuneration because the mothers did not become entitled to it from work or paid leave. Both trade unions therefore filed legal action with the Labour Court (sole national instance) due to an alleged breach of the respective collective agreements. The respective employer organisations were parties to the collective agreements and, therefore, law-based respondents in the legal action. The employer organisations supported their member employers.

In the pecuniary sense, the lawsuits covered the difference between the maternity allowance stipulated by law and the full salary for the respective 72 weekdays' and three-month period. Both employers naturally accepted the taking of the maternity leave, but objected to having to pay remuneration.

The lawsuits were based on the allegedly incorrect interpretation of the collective agreements as such, i.e. their wording and the need to pre- 
vent putting the mothers in a different position based on the number of pregnancies and the timing of the pregnancies. In terms of the law, the trade unions referred to national rules implementing the Pregnancy and Maternity Protection Directive 92/85, as well as to the Gender Equality Directive 2006/54. Further, both trade unions invoked the judgment in Case C-116/06 Kiiski (explained below in more detail) which referred, inter alia, to the sometimes unforeseeable nature of pregnancy.

In its substantively identical requests for a preliminary ruling, the Labour Court highlighted the interpretative weight of the manner of application (in this case negative for workers) of a clause in a collective agreement but - naturally - stated that compulsory law always takes precedence. On this basis, the Labour Court referred essentially the same question in both cases for a preliminary ruling, as follows:

\footnotetext{
“Do Directive 2006/54 ... and Council Directive 92/85 ... preclude national provisions of a collective agreement, or the interpretation of those provisions, under which a worker who transitions from unpaid leave (hoitovapaa) to maternity leave is not paid remuneration during maternity leave in accordance with the collective agreement?"
}

As the cited question shows, the case was in essence originally regarded as one case involving a discrimination dimension only, i.e. whether the weighty aspects of gender equality and maternity protection take precedence over the interpretation of the employer organisations' argument in these cases and lead to the payment of the maternity-leave remuneration.

\subsection{Question about the Parental Leave Directive: the Advocate-General's opinion}

Because the trade unions had invoked the judgment in Kiiski that dealt with the two successive leaves, namely those for longer term child-care and maternity, it is understandable on this basis, too, that the Court addressed to the parties in summer 2012 a written question about the very effect of the Parental Leave Directive 96/34 (its present version, directive $2010 / 18$, didn't apply at the material time. The trade unions naturally 
invoked this to support their claims and the employer organisations argued the opposite viewpoint.

The Advocate-General discussed the possible effect of the Parental Leave Directive in answering the question referred for a preliminary ruling (paras 66 to 84 of the opinion). Before reaching this conclusion, the Advocate-General first found that it was not justified to compare the situation of women who took maternity leave directly from work (i.e. paid leave) with those who switched from child-care leave to a new maternity leave (paras 79 and 80). The Advocate-General then highlighted the submission of the defendants' agents that the "return-to-work" condition on maternity-leave remuneration at issue was meant to create an incentive to return to work before a new child-related leave came into effect (para 81). The Advocate-General further found such an incentive consistent with the framework agreement (and thereby with the Directive) which itself refers in its fifth recital of the General Considerations to the importance of returning to working life (para 82). Finally, she found that the requirement of returning to work before a new and paid maternity leave is both necessary and proportionate; she relied here on the sixth recital that states how the requirements of undertakings and employees are alike (para 83).

\subsection{Court's reasoning}

The Court started its reasoning by citing established case law, according to which it is not bound only by the EU law provisions mentioned in the question referred for preliminary ruling (paras 32 to 34 of the judgment). In so doing, the Court introduced Directive 96/34 and reformulated the question referred: does this directive preclude the agreement-based national requirement of moving to remunerated maternity leave only from work - instead of from unpaid leave (para 35)?

The Court then noted the crucial angle, one of the two objectives in the European social partners' framework agreement that was the basis for Directive 96/34, as follows: 
"38.... TT] he framework agreement constitutes an undertaking by management and labour to introduce, through minimum requirements, measures to promote equal opportunities and treatment between men and women, by offering them an opportunity to reconcile their work responsibilities with family obligations (Case C-116/08 Meerts [...], paragraph 35, and Case C-149/10 Chatzi [...])."[Emphasis added]

Also, the Court naturally noted how, in its clause 2.5 , the framework agreement guaranteed the parental leave regime by requiring the return to work be on the same conditions as those applicable when the parental leave was taken (para 39, with reference to Case C-7/12 Riežniece). In para 41 the Court presented this agreement boldly as "European Union law". It further found that one type of leave under EU law, such as parental leave, should not affect the rights linked to another type of leave under that law, in this case maternity leave (paras 42 to 48). It then stated how the Finnish "return-to-work" requirement at issue meant renouncing in advance the right to paid maternity leave due to new pregnancy during the parental leave, and pregnancy is not always foreseeable (paras 49 to 51). The conclusion was that such a requirement dissuaded the worker from deciding to exercise her right to parental leave which, accordingly, undermined the effectiveness of Directive 96/34 (para 52). The conclusion was that the Finnish "return-to-work" requirement was incompatible with Directive 96/34 and, as a factual consequence, the workers must be paid maternity leaves, up to 72 days and three months, respectively. I explain below how the Finnish Labour Court for its part reasoned this outcome.

\subsection{Some case-related assessment in context}

Thus, the EU Court naturally based its analysis on an exploration and interpretation of the European social partners' framework agreement as a commitment and regime created by the social partners. In this sense, the CJEU acted as a Labour Court in interpreting a collective agreement. It is no surprise that the purpose of the agreement played a prominent role in the reasoning. On the contrary, the agreement's application practice was a minor issue because this was ultimately the first case of its type, i.e. a case 
concerning remuneration during a new maternity leave that starts during a period of parental leave.

The difference between the reasoning of the Advocate-General and that of the Judges is salient in this case. The Advocate-General found, inter alia, that a comparison between women transitioning to maternity leave from work (or paid leave) and those transitioning to it from unpaid leave was not justified. Perhaps the most radical difference appears in the Advocate-General's position - after having accepted the incentive argument of the defendants on return to work - that the requirement of returning to work as a precondition for the new remunerated maternity leave was even necessary (para 83 of the Opinion). In fact, this implied putting a ceiling on the regulatory competence of management and labour concerning the remuneration during maternity leave. Such an approach could be criticised heavily and at length but some remarks suffice here.

Hence, the regulatory competence - and a right to collective bargaining and agreements - of management and labour is based on freedom of association, enshrined in ILO Conventions No 87 and 98, as well as in the European Human Rights Convention (ECHR), not to mention the Charter of Fundamental Rights of the EU itself. In order to be legitimate, limiting the regulatory competence must be, inter alia, "necessary in a democratic society" (see under the ECHR, particularly judgment Demir, application 34503/97, paras 154 to 170). Besides, such a ceiling would manifestly contradict the minimum nature of the Maternity Protection Directive 92/85.

The analysis of the Judges was completely different from that of the Advocate-General. It was based on the question of whether Directive 96/34, with the framework agreement as its integral part, thus, "European Union law" (para 41) permitted the Finnish collective agreements' "return-to-work" condition at issue. This also implied the question of whether Directive 96/34 was intended to create rights for individuals, naturally rights ultimately obtained through national law or collective agreements.

The outcome of the Judges' analysis certainly meant that rights were created for individuals in a normative pattern comprising parental and maternity leaves. However, this was not excessive judicial activism, because the judgment's starting point (paras 38 and 39) in the two objectives was the social partners' framework agreement: (i) their commitment to use the framework agreement to create an actual parental-leave regime 
(ii) that would not undermine the working conditions (cf. in this case the maternity-leave conditions) of a worker taking parental leave.

Still, the Judges' reasoning was anchored in the classical EU law concept of safeguarding the effectiveness (effet utile) of Directive 96/34, i.e. that the conditions of the maternity leave shall not dissuade female workers from taking the parental leave. Effet utile is so generally accepted and is in fact a general principle of EU law that no reference to any case law was necessary in para 52 of the judgment, hence not even in the field of the social partners' framework agreements turned into EU law with a directive. As for the decisive impact of effet utile (principle of effectiveness) in this particular respect, see e.g. joined Cases C-395/08 and 396/08 Bruno and Pettini, para 73, in the context of the framework agreement on part-time work (Directive 97/81). As such, it is established case law that in a situation where several interpretations of an EU norm are possible, the one retaining the norm's effectiveness must take precedence (see e.g. Case 187/87 Land de Sarre, para 19 and the case law cited).

By returning to the difference between the Advocate-General's analysis and that of the Judges, it is also worth noting how the former saw the Finnish maternity leave conditions at issue as a prolongation of and compatible with the fifth and sixth recitals in the general considerations of the framework agreement. First of all, the Judges noted the overall purpose of the parental leave regime, as set forth in the preamble to the framework agreement (and reflected in the judgment's para 38). It is essential, however, that the Judges completely disregarded those recitals and based their reasoning on the practical realisation of the parental-leave regime itself as created by the corpus text of the framework agreement, i.e. its clauses 1 and 2 with relevant paragraphs.

It is true that the reasoning in the judgment was based on the practical status, ultimately the rights, of the female workers instead of a vague formula of "taking into account the needs of both undertakings and workers," as the sixth recital of the general considerations substantively runs. The assessment of that practical status even covered the sometimes unforeseeable nature of pregnancy. Thus, the judgment achieved even a biological dimension; a "real life argument" was given weight.

In conclusion, the CJEU's judgment TSN-YTN is of the EU's true labour law. 


\subsection{Epilogue in the Finnish Labour Court}

In its two substantively identical judgments of 22nd August 2014, the Finnish Labour Court closed the judicial circle. The trade unions conducting the cases naturally invoked at this stage the preliminary ruling of the CJEU and, thus, Directive 96/34.

It is notable, firstly, at this post-CJEU stage, that the employer organisations arguments before the Labour Court was that it should dismiss the lawsuits for procedural reasons, namely that the Finnish Code of Judicial Procedure includes a prohibition of amending the lawsuit. On this basis, the employer organisations stated that the workers could not rely on Directive 96/34. The Labour Court disagreed and reasoned that the claims in the lawsuits were not amended but just given a new line of reasoning, which happened during the preliminary phase of the case. The preliminary ruling procedure took place during that phase.

Secondly, the substantive reasoning of the Labour Court merits some remarks. It first noted that Directive 96/34 precluded a collectiveagreement provision requiring returning to work as a condition for paying the maternity-leave remuneration, as defined in the respective collective agreements at issue. However, the Court did not follow a "direct" interpretative route regarding the provisions in those collective agreements (see below). It took a safe route via national law.

Thus, the Labour Court noted the interpretative effect of EU law at national level, relying expressly on the classical judgments Wagner Miret (C334/92, para 20) and Pfeiffer et al. (C-397/01 - C-403/01, para 113). The former cites a complete implementation of EU law as the presumption for interpreting and applying national implementation law. The latter specifies the obligation to interpret and apply national implementation law as far as possible in accordance with the wording and purpose of an EU directive in order to reach its goals. Thus, this EU law reasoning was the Court's bridge to national law implementing Directive 96/34, i.e. to the application of the respective mandatory rules (rights) in the Employment Contracts Act. The Court laconically stated how those rules had to be applied as far as possible in accordance with the contents and goal of the Directive.

The rest of the Court's reasoning was accordingly succinct. The interpretation of the provision in the collective agreement on maternity-leave 
remuneration, as proposed by the employer organisations, would endanger the full realisation of the mandatory rights enshrined in the Employment Contracts Acts, for the reasons stated in the CJEU's judgment TSNYTN. Therefore the interpretation of the collective agreement proposed by the employer organisations, i.e. returning to work as a condition for paying the remuneration during a new maternity leave, would be contrary to the mandatory rules of the Employment Contracts Act.

As a conclusion in both cases, the respective maternity-leave remuneration was ordered payable, but the trade unions' claims of a breach of the collective agreement - usually resulting, if the breach is established, under the Collective Agreements Act [in] the payment of a separate compensation to the trade union - were dismissed because the issue was "open to various interpretations". Each party had to pay its own legal costs. The two judgments were unanimous.

Following the Labour Court's judgments, identical out-of-court settlements concerning various collective agreements have been reached.

\subsection{Some national, Nordic and European reflections}

The Finnish labour-law audience, at least among employers, was somewhat astonished by the CJEU's TSN-YTN judgment. The traditional thinking in Finland had been framed by the idea that whereas neither national law nor Directive 92/85 laid down an obligation for employers to pay any salary during maternity leave, only non-discrimination rules have limited social partners' competence to conclude agreements thereupon. In Finland, the state pays the maternity allowance (equivalent to sickness allowance) as part of social security benefits. However, as early as the CJEU's judgment Kiiski in 2007, a pay element (covered expressly by the third question referred for preliminary ruling and by "rights attached to that maternity leave" in the end of the statement of judgment) was included but without any "return-to-work" condition in the collective agreement or its practical application. Further, Kiiski included the idea that the use of one type of leave should not adversely affect another type. These aspects prompted new thinking by trade unions, leading to the salary cases before the Labour Court. In addition, the Labour Court also referred to Kiiski in the grounds of 
its request for a preliminary ruling. Even so, the Labour Court was unconvinced that a Kiiski a rule of law applied to the TSN-YTN case.

However, it was the first time the Finnish labour-law parties had experienced a Finnish labour-law case in which the CJEU's powers - established case law as such - settled the issue in a preliminary ruling with EU norms beyond the national court's question. Accordingly, Directive 96/34 applied to these cases in full on the initiative of the CJEU. The preliminary ruling process is elastic - a kind of a judicial question-and-answer game and supersedes traditional national civil-law procedure. Accordingly, the TSN-YTN judgment shows how the interpretation and impact of EU law can result from a combined reading of various legal instruments and principles. As such, the combined reading - sometimes even the reading of a "normative complex" - can in principle start with the Treaties and fundamental and human rights instruments, and then, via general principles of EU law and the directives, result in a framework agreement between management and labour.

However, in the TSN-YTN case, the interpretative reasoning covered "only" two minimum Directives. The crucial element was that the national maternity-leave provisions in a collective agreement, higher as such than the minimum required by the Maternity Protection Directive 92/85, must not undermine the effectiveness of the Parental Leave Directive 96/34 (and the respective framework agreement). This way, the minimum nature of the regime established by the latter took effect at a higher level than the minimum level established by the former.

At the same time legal circles in both Finland and even the Nordic countries in general - I dare to say - received a concrete lesson of the consequences of raising the European social partners' framework agreement up to the European Union law (TSN-YTN, para 41). As such, [in] the Greek Case C-149/10 Chatzi the CJEU had already shown how a framework agreement (on parental leave in Chatzi, too) is an integral part of the implementing directive and therefore subject to the general interpretation principles in EU law. Thereby the principle of effectiveness (effet utile) of that law in TSN$Y T N$ became to guarantee the framework agreement, too, as substantively effective. On this basis, one can note that, if the TSN-YTN judgment is criticised by employer organisations in Finland or other Nordic countries, they should file a complaint with UNICE/BusinessEurope and CEEP. 


\section{A European Minimum Wage}

Jens Kragh ${ }^{25}$

\subsection{Introduction}

"Emphatically no!!!" This has been - and still is - the brief, but clear, response of Nordic trade union confederations whenever a great many other confederations in the European Trade Union Confederation (ETUC) have proposed a European minimum wage policy.

Does the EU have competences as regards wages and, if so, how does the EU use these competences? Which kinds of minimum wage are there in the EU and how widespread are they? What is the background for and contents of the years of discussion in the ETUC on minimum wage? These are some of the questions that are sought to be answered in the following.

\subsection{Does the EU have competences as regards wages?}

Article 153 of the Lisbon Treaty lists a number of areas in which the EU supports and supplements the efforts of Member States, e.g. in regard to working conditions. However, Article 153(5) specifies that "The provisions of this Article shall not apply to pay." In the ongoing discussions of the EU's competences as regards wages, this is the very article to which reference is made when it is claimed - often bombastically - that the EU has no competence as regards wages.

${ }^{25}$ General secretary of FTF, the Confederation of Professionals in Denmark. 
The contents of Article 153(5) are explained in more detail in grounds 123-125 of the EU judgment of 15/4/2008 in C-268/06 (Impact), which specify that the determination of wage levels is a national matter, and "in those circumstances, in the present state of Community law, it was considered appropriate to exclude determination of the level of wages from harmonisation."

Furthermore, it is specified that the exception of Article 153(5) "must therefore be interpreted as covering measures - such as the equivalence of all or some of the constituent parts of pay and/or the level of pay in the Member States, or the setting of a minimum guaranteed Community wage - which amount to direct interference by Community law in the determination of pay within the Community." However, it is also specified that "it cannot be extended to any question involving any sort of link with pay."

Consequently, according to the Treaty, the EU cannot interfere directly in the wage levels of individual Member States, just as the EU cannot harmonise these levels or introduce an EU minimum wage.

In order to understand the EU's competences as regards wages, it is, however, not enough to focus only on Article 153(5), because the Treaty covers other significant - and in this context relevant - competences as regards free movement within the Internal Market, as well as social and labour market policies. Via these competences, the EU does actually, to a varying extent, influence wage conditions, e.g. for migrating workers, posted workers, part-time workers, fixed-term workers, as well as temporary workers. Gender equality directives and the Working Time Directive are other significant directives relating to wage conditions.

However, one important focus area is the EU's competences related to the economy and employment.

\subsection{The crisis changed the legal basis}

In Articles 145-149 of the Treaty, the EU is given a number of important tasks relating to the economy and employment. For example, the Council may issue recommendations to individual Member States on labourmarket reforms. However, it must be stressed that the EU does not have the competence to harmonise Member State rules in this field. 
The economic crisis put enormous pressure on the EU, making it necessary to introduce a number of noteworthy, sometimes drastic, agreements and interventions to keep the EU together, not least as regards the euro zone.

The decisive elements were the Europe 2020 strategy from 2010 and a number of intergovernmental agreements concluded subsequently, since these have considerably changed the economic management and coordination of the EU - also with possible consequences for wage formation in the individual countries. At institutional level, the period has seen the strengthening of the European level in relation to the national level, and the European Council and European Commission have been strengthened in this field in relation to the European Parliament.

The purposes of the Euro Plus Pact, adopted in March 2011, include a strengthening of competitiveness. Each country is responsible for the specific measures taken to ensure competitiveness, but special attention is paid to ensuring that cost development does not outpace productivity development, just as an assessment is made of wage-determination systems, the degree of centralisation of the negotiation process, as well as indexation mechanisms.

The Six-Pack, adopted in November 2011, is intended to strengthen budgetary discipline, coordinate economic policies and monitor macroeconomic imbalances. As a part of the follow-up on the Six-Pack, "scoreboards" of economic indicators are to be prepared, including wage-related indicators, such as percentage changes of unit wage costs.

The Fiscal Compact - also called the pact for the euro - on economic coordination and budgetary discipline is the latest addition to what is called "New Economic Governance". The Fiscal Compact was adopted in January 2012. It encouraged even stricter management of Member-State fiscal policies, thus also covering possible influence on collective bargaining.

With these intergovernmental agreements, the strength of the EU's competences relating to the economic policy of Member States, including negotiation and pay systems, has been strongly enhanced. The most important tools are the Troika and the European Semester. 


\subsection{The Troika sets a new agenda}

In 2010, the economic crisis was about to bring down severely debtridden Greece, and questions were asked as to whether Greece could continue as a member of the euro zone. Some even questioned whether the euro zone could be maintained in the long term.

It was in this atmosphere that in May 2010, the heads of state and government within the euro zone decided to offer Greece financial support and establish the so-called Troika, consisting of the European Commission, the International Monetary Fund and the European Central Bank.

The Commission's authority for its work in the Troika comes from the euro-country treaty on the European stability mechanism for debt-ridden euro countries, not from the EU Treaty. One consequence of this is that the democratic control, etc., normally exercised by the European Parliament over the Commission does not apply to the Commission's work in the Troika. Incidentally, the Parliament recently criticised the lack of transparency of the Troika's decision-making processes.

The Troika signified a new political and economic reality, since, as a "European" institution, it gained direct influence on national policies in certain countries - also relating to negotiations and wages. In the years that followed, the Troika made extensive requirements from the so-called programme countries (Greece, Portugal, Cyprus, Ireland and, partially, Spain) as regards privatisation and deregulation of public welfare services, as well as the reduction of public expenditure for pensions, health and education, etc. In terms of negotiations and wages, the Troika has focused on the following:

- Decentralisation of collective bargaining, e.g. abolishment of certain national agreements, restricting the contents of sector agreements, company agreements rather than sector agreements, and the possibility of non-union-members concluding company agreements.

- More restrictive criteria for making labour-market agreements generally applicable.

- Reducing/freezing of minimum wages.

- Reducing/freezing of public-sector wages, and pensions in particular.

- Management of wage trends related to productivity developments. 
In a number of countries, the Troika's tough demands have triggered serious social and political unrest. As regards labour-market agreements, one consequence of the dramatic interventions has been a considerable decline in labour-market contract coverage.

Naturally, the ETUC has strongly criticised the Troika's policy. This has included pointing out that, with its actions in the Troika, the Commission is in breach of basic principles of the Treaty, including Article 153(5), and that the ECB does not have the mandate, competence or expertise to be a full member of the Troika.

It should also be noted, however, that the Troika's strict demand to reduce the minimum wage in Greece has been criticised, e.g. by the expert committee of the Council of Europe, which finds that these reductions are incompatible with Article 4 of the Social Charter, which states that everyone has the right to fair remuneration.

\subsection{Softer management through the European Semester}

As part of the Europe 2020 strategy and economic management in general, the European Semester was introduced to integrate the various elements of cooperation of Member-State economic policies. This coordination covers the so-called stability and convergence programmes submitted by Member States to the Commission, and the National Reform Programmes and reports under the Euro Plus Pact. The whole process ends with the adoption of country-specific recommendations.

In the annual growth statement which starts the European Semester, the Commission presents more specific statements on topics such as wages and productivity; however, it is through the country-specific recommendations in particular that the EU influences the negotiation and wage structures of the individual countries. These recommendations, which are intended to support reforms in Member States, are not legally binding, but since they have been approved by the heads of state and government, it goes without saying that countries cannot just ignore them. Since there is a dialogue in the process between the Commission and the individual government, it is not impossible that some of the recommendations are 
more or less based on wishes expressed by the national government, so they are welcomed. These recommendations must be seen as a relatively soft type of management and are often accompanied by a comment to the effect that countries should implement them "in consultation with the social partners and in accordance with national practice."

In 2014, the country-specific recommendations in the field of negotiations and wages covered thirteen countries, including the programme countries involved with the Troika. The recommendations focused mainly on the following items:

- Wage indexation systems should be reformed to ensure that wages do not grow more than productivity.

- The minimum wage should develop to promote employment and competitiveness.

- Labour-market bargaining should be decentralised, i.e. from sector to company level, and companies should be offered an "opt-out" from sector agreements; in addition, differentiated wage increases should be promoted.

- Labour-market bargaining should lead to moderate wage increases.

As is evident, there is a high degree of concordance between the mindset of the Troika's demands and the country-specific recommendations. It should also be noted that the recommendations largely concern elements about which the EU is not able to make binding decisions in the light of Article 153(5) of the Treaty, but where the EU is able to use its other competences in the Treaty and the intergovernmental agreements.

2014 saw no recommendations to Denmark, Finland or Sweden regarding their negotiation and wage systems; however, in 2013, Denmark and Finland received recommendations also covering the question of a more moderate wage development. In 2012, Finland was advised to continue its effort to match productivity development with wage development, while Sweden received a recommendation to strengthen wage flexibility at the lower end of the wage scale.

There are naturally many reasons why Denmark has only received one recommendation regarding negotiation and wage systems. Some of them have to do with the fact that, before the millennium, Denmark changed its 
negotiation systems quite markedly, particularly in the private labour market, to strengthen competitiveness. The indexation system (the net price indexation scheme) was suspended in 1983 and ultimately abolished in 1987, while in subsequent decades negotiations were simplified by becoming widely decentralised to be carried out at company level. The regulation scheme, which intends to ensure balanced wage development within the public and private sectors, has meant that a responsible financial approach in the private sector has been consequential for wage trends in the public sector.

In the discussions about a European minimum wage, it has been pointed out, via the country-specific recommendations, that the $\mathrm{EU}$ is able to promote a common European minimum wage practice if the EU so desires. Some even think that this could mark the beginning of directives being introduced in this field. For this to happen, however, the Treaty would have to be amended.

This is an unlikely scenario for many years to come, but it is noteworthy that the many wage-related recommendations in recent years have common features. These are not recommendations to harmonise wages, but rather soft harmonisation of wage-formation principles.

\subsection{Minimum wages in European countries are highly diverse}

In some cases, the arguments in favour of a reasonable minimum wage as a social right are based on the UN Human Rights Declaration or the ILO Constitution. More commonly, reference is made to the Council of Europe's Social Charter of 1961 and the EU's 1989 Community Charter on the fundamental labour market and social rights of workers, which both state that everyone has the right to fair remuneration.

However, the basic arguments for a European minimum-wage policy have been expanded over the years. Since the EU opened up to central and eastern European countries in 2004, the argument for a minimum wage as a tool to fight social dumping has become more prominent; in recent years, not least the ETUC - but also the Commission, vaguely formulated - 
have argued in favour of increasing the minimum wage to promote consumption and employment and combat deflationary trends.

A number of events have made the question of a European minimum wage policy more topical.

Firstly, a couple of national events have furthered this discussion: Germany's introduction of a statutory minimum wage from 1st January 2015 and the Italian government's proposal to introduce a minimum wage as part of a labour market reform. However, events at EU level have also furthered this discussion. Up to the elections for the European Parliament in the spring of 2014, the S\&D Group in the Parliament proposed a European framework agreement for the gradual introduction of minimum wages, either through legislation or collective bargaining.

What is equally noteworthy is that, in connection with his appointment, the new President of the Commission, Jean-Claude Juncker, stated that he is in favour of all Member States introducing a minimum wage adapted to the national negotiation traditions and economic conditions. Whether the Commission will take initiatives in this field is yet to be seen, but many see this statement merely as a necessary political statement for the benefit of the Parliament, since the Parliament backed him as new President of the Commission in the new procedural structure for election to that office.

There are three different models in Europe for determining minimum wages: a statutory minimum wage, generalisation of labour-market agreements (which may contain statutory elements) and an agreementbased minimum wage. The most common structure is to have both a statutory minimum wage and generalisation. Only Denmark, Sweden and Italy do not have a statutory minimum wage or generalisation; however, as mentioned, it is being discussed in Italy right now whether a statutory minimum wage should be introduced. None of the Nordic countries has a statutory minimum wage, but Finland (as well as Iceland and Norway outside the EU) have generalisation.

In the autumn of 2014, Denmark had some discussion of a statutory minimum wage or generalisation of labour-market agreements. Some of the reasons have been that, as mentioned, Denmark is one out of just three EU countries with an agreement-based minimum wage only; the fact that EU politicians are increasingly discussing a minimum wage in Europe; and 
the fact that there are currently problems with social dumping. Given this situation, it has been suggested that trade unions should discuss whether it would be appropriate to introduce a generalisation model as it exists in Norway. However, leading employer organisations and trade unions strongly resist discussing this sensitive issue, because it is felt that the Danish model will be able to handle the challenges of social dumping and because it is feared that a statutory minimum wage or generalisation of labour-market agreements would weaken the incentive to join a trade union, which would undermine the Danish model.

A statutory minimum wage is common in the EU, since only five countries (Denmark, Finland, Sweden, Italy and Austria) out of the $28 \mathrm{EU}$ countries do not have a statutory minimum wage. In 2014, the statutory minimum wage varied from EUR 11.00 in Luxembourg to EUR 1.00 in Bulgaria. In most countries, the statutory minimum wage is around EUR 4.50 or less per working hour. In 2012, statutory minimum wages ranged from 36 to $62 \%$ of median pay and 30 to $50 \%$ of the average pay in the individual countries.

In countries where the minimum wage is based on labour-market agreements only, it is difficult to ascertain the size of the normal minimum wage, since the minimum wage varies from one area to the next. Generally, Nordic agreement-based minimum wages are considerably higher than statutory minimum wages in other EU countries, and the Nordic countries have far fewer "working poor" than other EU countries.

Naturally, there is an ongoing discussion of what is a reasonable minimum wage or fair remuneration. For years, the ETUC has used the Council of Europe's definition of "fair remuneration", which has as its objective at least $60 \%$ of the average net wage and certainly not less than $50 \%$. Since this definition includes both taxes and social services and is thus complex to put into operation, the ETUC has recently referred to the OECD's definition of a low-pay limit, which is two-thirds of the national median wage. However, the ETUC is also trying to implement a "living wage", i.e. a wage that enables the individual wage-earner to live a decent life. 


\subsection{The ETUC is divided on the need for a European minimum-wage policy}

Since Socialist Jacques Delors was President of the Commission, the political leaders of ETUC have spoken in favour of a European minimum-wage policy and have tried to win acceptance of this approach. However, this has resulted in major upheavals.

At the ETUC congress in Seville in 2007, there was a lively discussion of the challenges of social dumping and a European minimum wage; however, since opinions were highly divided, the congress manifest only ended up stating that the ETUC would "campaign for increasing the minimum wages and real pay increases for European workers."

The next congress was held in Athens in 2011, while the crisis was raging in Europe in general and in Greece in particular. The discussion from Seville was back on the agenda, but attitudes were sharper. Again, the congress had to give up on finding a compromise and postponed the question to a chairmanship meeting in Copenhagen in February 2012. Strong solidarity and active lobbying enabled the Nordic organisations to win the day for a compromise, which was then also put into words in the ETUC proposal from June 2012 for "A Social Compact for Europe". This wording includes the following:

\footnotetext{
"Wage-setting to remain a national matter and to be dealt with according to national practices and industrial relation systems. Negotiations between social partners at the relevant level are the best tool to secure good wages and working conditions; the statutory minimum wage, in those countries where trade unions consider it necessary, should be increased substantially. In any event, all wage floors should respect Council of Europe standards on fair wages."
}

In the years that followed, the Nordic organisations tried to maintain this compromise. This was done most recently in connection with the preparation of the ETUC congress in Paris in 2015, where the first draft manifest for the congress stated that the EU should adopt a clear and ambitious social agenda with initiatives and/or standards including fair wages for all workers.

The Nordic organisations took a strong stance against this wording and insisted that the 2012 compromise be maintained, and they seem like to succeed. 
Efforts are currently being made in the ETUC to formulate a more nuanced wage policy, also based on the assumption that a joint European minimum wage stated in euros is not realistic, since the current minimum wages in the EU countries vary considerably, as minimum wages in the individual countries must be seen in relation to price levels in the countries, and as the institutional set-up for determining a minimum wage varies considerably from one country to the next.

The basic view of the Nordic organisations over the years has been that the EU should not interfere with the Nordic countries' agreement models and wage determination. These are national competences. In this connection they have stressed that wages in the Nordic countries are determined through collective bargaining and that the government's interference is limited. They have stressed that the Nordic countries are not without minimum wages, but that they are based on labour-market agreements, not legislation.

The Nordic organisations have found it important not only to defend, but also to explain, the Nordic models, including the more than 100-yearold tradition of collective bargaining and wage determinations, as well as a high percentage of trade-union membership and labour-market agreement cover. Furthermore, they have also tried to state clearly and unequivocally that, in their view, the Nordic negotiation and wage models will not be suitable in all other EU countries, where historical and current conditions are essentially different from those of the Nordic countries.

The Nordic organisations have faced a wide variety of organisations with entirely different traditions and preconditions. For example, the organisations in eastern Europe only have rather short traditions of free wage bargaining, and the will of politicians and employers in those countries to strengthen such negotiations is often limited. It should be added that both the eastern European organisations and a number of organisations in central and southern Europe have relatively modest trade-union membership percentages, and labour-market agreement cover is poor, although in a few countries generalisation is widely used.

Incidentally, the countries concerned are typically economically weak in that they have been hard hit economically and in terms of employment and otherwise by the economic crisis. For example, in many cases wage developments have been unable to keep pace with price or productivity 
developments, and social inequality has worsened dramatically. The trade unions in those countries would like for the EU - and the ETUC - to work to improve wages and working conditions, preferably through the determination of a European standard for fair remuneration.

\subsection{Conclusion}

As stated, there is no basis for bombastic statements to the effect that the EU has no competences in regard to wages. The EU may influence wage formation in Member States, not only by virtue of the Treaty, but also via intergovernmental agreements concluded during the economic crisis.

As mentioned, the Treaty does not allow the EU to intervene directly in the setting of wage levels in individual countries, just as the EU cannot harmonise these levels or introduce an EU minimum wage. However, via the European Semester, the EU may make significant recommendations which are not legally binding, but politically difficult to disregard. Furthermore, with its special competences, the Troika may make direct demands for changes of the negotiation and wage systems, which the Troika has also done to a great extent.

The extent to which the negotiation and wage systems of the Nordic countries will be affected by recommendations under the European Semester will depend, not least, on the economic development in these countries, including their sovereign debt, competitiveness, employment, etc. In this connection, the Nordic countries will not be "spared" merely because wage formation is achieved through collective bargaining.

One special dimension consists of discussions of the level and content of national, statutory minimum wages. The levels and content of minimum wage schemes vary widely from one country to the next, and the set-up for determining minimum wages also varies markedly. Consequently, for legal as well as political reasons, actual determination of a minimum wage by the EU does not seem realistic within a foreseeable future.

In recent years, the EU has undoubtedly taken greater interest in the wage formation of Member States, including aspects relating to a minimum wage. Also, the Nordic models are undoubtedly and increasingly becoming the exception in Europe. In this situation, the question is 
whether Nordic interests are best served by maintaining that the EU has no wage-related competences, or whether Nordic trade unions should instead get involved in European discussions of wage formation, including minimum wages. We have certainly not seen the end of this matter.

\subsection{References}

Eldring, L. \& Alsos, K. (2014). Lovfestet minstelønn: Norden og Europa - en opdatering. Fafo .Memo for NFS.

ETUC. Various internal material items regarding the winter school for presidents in 2012, the summer school in Collective Bargaining Coordination Committee 2014, and the draft congress resolution from the 2015 congress.

ETUC (2014). The functioning of the Troika: A report from ETUC.

Kristiansen, J (2013). Aftalemodellen og dens europæiske udfordringer. Jurist- og Økonomforbundets Forlag.

Müller, T. (2014). The king is dead - long live the king: what follows after the Troika, ETUI.

Schulten, T. (2014). Contours of a European Minimum Wage Policy, Friedrich Ebert Stiftung.

Schulten, T. \& Müller, T. (2014): European economic governance and its intervention into national wage developments and collective bargaining.

Schulten, T. \& Müller, T. (2014). Back on the agenda: a European minimum wage standard. ETUI Policy Brief, no. 8. 



\section{The EU's Attempt to Regulate Wages in the Financial Sector}

Ella Sjödin26

\subsection{Introduction}

Major problems were revealed concerning North American mortgage bonds in 2007 and 2008. The balance sheets of a majority of the major US credit institutions imploded when the institutions were forced to write down assets to the tune of hundreds of billions of dollars. The consequence was an acute liquidity crisis, which spread across the world and which in turn led to a global financial crisis.

Hardest hit by the crisis were US and continental European financial institutions and British banks. The Nordic Area was not unaffected by the crisis. In both Denmark and Sweden, the state was forced to make money available to the banking systems to maintain trust in the financial system. The Swedish government, for example, expanded the deposit insurance in the autumn of 2008 to protect savers and to ensure that they continued to have faith in banks. In Denmark, different "bank packages" were set up with far-reaching state guarantees to safeguard financial stability. According to a report submitted to the Swedish Fiscal Policy Council by Claes Bergström, of the Stockholm School of Economics, a large number of banks in the Nordic Area were forced to write down assets. The greatest

${ }^{26}$ Head of EU affairs at the NFU, the Nordic Financial Unions. 
and most dramatic effects of the crisis hit Iceland where several of the country's biggest banks went bankrupt. The Nordic countries were dragged down by the global spiral of a lack of trust and liquidity problems.

Not only did the financial crisis have enormous consequences for society at large but also for employees in the Nordic financial sector. The direct impact was huge cutbacks in the financial sector which hit several of the Nordic countries hard as tens of thousands of employees lost their jobs. The working situation of these employees deteriorated as a consequence of redundancies and cost savings, creating a harsher working climate. Employees in the financial sector are increasingly vulnerable to stress caused by a fear of being made redundant combined with highperformance and sales goals as well as severe criticism against banks in the media, generally referred to as bank-bashing. In a report on bankbashing by the Financial Sector Union from 2013, it is possible to read how media coverage of and statements by politicians on the financial crisis have led to an increase in threats and criticism levelled by customers against bank employees.

The response of the EU to the financial crisis was to reform financialmarket regulations in Europe. The large number of new laws has created a complicated network of financial-market legislation and the consequences of this have yet to be investigated. The regulations that applied before the crisis were not sufficiently strict nor was compliance sufficiently followed up. The wave of new EU legislation resulting from the crisis deals with everything from supervision, capital requirements and consumer protection to financial stability. In addition, new European authorities for the supervision and compliance of regulations have been established, all to avoid another financial crisis of similar proportions.

In its quest to tighten up the financial sector, the European Commission has also intervened in areas where the social partners have an exclusive right to regulate through agreements. These interventions have without exception involved wage. Moreover, the NFU (Nordic Financial Unions) has noted how the EU's supervisory bodies in the financial sector the EBA, EIOPA and ESMA - have also encroached on the area of wages in their guidelines for the national interpretation of different directives.

The Commission's attempt to encroach on the social partners' right to free wage-setting has been a reality in the financial and insurance sectors 
for a number of years. The situation may be exceptional in the financial sector due to the financial crisis. However, if the EU is able to encroach unhindered on the area of remuneration in the financial sector, there is a risk that this will spread to other sectors.

In this perspective, the NFU's work to secure an exemption for the remuneration policies in the collective agreements from provisions in the Capital Requirements Directives (see below) may be decisive for how the EU acts in other sectors in the future. Moreover, the social partners' influence has tended to decrease in the past few years, for example, through a weakened social dialogue, most clearly illustrated in the stopping of the proposed occupational health and safety directive in the hairdressing sector (negotiated by the social partners in social dialogue), and by the fact that consultation in the labour-market area is no longer exclusively for the social partners at the European level but is open to the general public which reduces the impact of trade-union views since the views of several actors must be considered by the EU. These two factors mean that it is important for trade unions in Europe to clearly voice their opinion against the developments and in favour of their special status in wage setting and other issues that are the remit of the social partners.

\subsection{The Nordic model}

The Nordic model presupposes that it is the social partners who are best placed to set wages and working conditions for employees. In the Nordic Area, it is the social partners and trade unions which work with wage formation, through collective bargaining by the partners. The state does not participate in wage formation but creates the preconditions for the partners to do their job. Wage formation through collective agreements in free negotiations between the social partners is a fundamental cornerstone of the Nordic model.

The right to engage freely in collective bargaining has been under pressure at EU level for a long time now, as the regulation of wage formation and other central labour-market issues through collective agreements is uncommon outside the Nordic Area. In many other European countries, it is more common to regulate the labour market through legis- 
lation, and the EU's proposal regarding financial sector wages lies closer to the European tradition in this regard. This is despite the fact that the right to collective bargaining and wage formation between the social partners is enshrined in Article 153(5) of the Treaty on the functioning of the European Union (TFEU), which states that wage formation is a strict national competence in which the EU may not intervene.

\subsection{The financial crisis and the wish to regulate}

Before the financial crisis, the EU took a completely different approach to financial market regulation compared to today. The European Commission's White Paper on the Financial Services Policy (2005-2010) set out the central areas in the regulatory work. The point of departure was better legislation, which meant that only the most necessary rules should be implemented. Current regulations were to be reviewed and, if possible, simplified. Regulatory development in the area of financial services was to be governed by a user perspective to minimise the regulatory burden. Obstacles to cross-border consolidation were to be abolished, and the integration of financial markets in the EU was to be improved.

As already implied, the financial crisis fundamentally changed this view. Of the countless areas subjected to reinforced rules since 2008, the area of wages is key for the NFU. When the European Commission has tried to exert influence over national wage formation, the reason given has been that wage formation is strategically important for competiveness and employment. These arguments were put forward by the Commission to the Council's Advisory Committee on Employment and Social Affairs in 2013, but did not gain traction at that time due to strong opposition from the European social partners.

One factor that has been discussed as a contributory factor to the crisis was the bonus regimen in place in, primarily, British and US financial institutions. When the Commission started to target wage regulation in the financial sector, the legislators had seen the results of reckless risk-taking in the sector where it was possible for some to make huge profits. The bonus schemes created a culture of speculation that promoted short-term risk-taking with borrowed money, at the expense of a more long-term 
approach. The bonus schemes were performance-based and concerned mainly management and certain key people with an enormous impact on the risk profile of a company. Another reason why financial companies dared to take such huge risks was the fact that their operations were (and are) guaranteed by the state because of their special status in society as payment intermediaries and credit givers. ${ }^{27}$ In response to this, the European Commission wanted to identify risk-takers at financial institutions and prevent their risk-taking. It started by regulating the bonus schemes of the managements of banks but subsequently moved on to ordinary employees at banks and insurance companies.

\subsection{How the EU approaches wage regulation}

When the European Commission starts to draw up new legislation, it often opens up for companies, private individuals and stakeholders to participate in a consultation process to give their views of the proposal. For the $\mathrm{NFU}$, it soon became clear during the consultation processes that the issue of wage regulation in the financial services sector had gained traction after the financial crisis. Wages were now to be regulated through a number of proposed new regulations.

The NFU's opposition to the Commission's attempts to regulate wages has borne fruit, however. The NFU claims that, despite the fact that the EU lacks the competence to regulate wages, there is/has been a lack of knowledge about this and a lack of understanding for how the Nordic model works. The NFU has managed to gain support by underlining that wage formation through free negotiations between the social partners is a cornerstone of the economic model of the Nordic countries. There are now exemption clauses for the social partners in central regulations and the Commission is now, for example, targeting the incentives that wage systems in banks and insurance companies create rather than the scope and level.

\footnotetext{
${ }^{27}$ Att förebygga och hantera finansiella kriser (Preventing and Managing a Financial Crisis), Statens Offentliga Utredningar (Commission of Inquiry reports) 2013:16.
} 
Despite the fact that the Commission's knowledge about the Nordic model has been heightened, the NFU has noted how the EU's supervisory bodies in the financial sector (the EBA, EIOPA and ESMA) also encroach on the area of wages in their guidelines. One of the tasks of the European supervisory authorities is to interpret legislation in the area of financial services and subsequently produce more detailed and technical guidelines for implementation at national level. It has thus become clear to the NFU that the supervisory authorities play an important role in shaping EU legislation in the financial sector. If the European supervisory authorities make more far-reaching interpretations of the rules on incentive-creating remuneration systems than intended by the legislators, this might result in the EU regulations having an impact on national wage formation despite the influence of the NFU.

\subsection{Regulatory trend}

There are a large number of areas besides wages and remuneration that have been the post-crisis focus of the EU's legislative work concerning the financial sector. There are different assessments regarding the total number of rules, but an estimate is that the total number of pages of legal text that have been produced (including binding Recommendations and Guidelines) amount to over sixty thousand. According to Commission Communication COM (2014) 279, the aim of all new rules is to provide one uniform regulation for the financial markets in the EU. By and large, over forty different proposals in five main areas are grouped together: restoring and deepening the EU Internal Market in financial services; establishing a Banking Union; building a more resilient and stable financial system; enhancing transparency, responsibility and consumer protection to secure market integrity and restore consumer confidence; and improving the efficiency of the EU financial system.

Apart from the above-mentioned bonus schemes, the question of incentive structures in the sale of financial products and services as well as consultation in the same area has been discussed in several areas. The EU has wished to do something about the weak consumer protection in this area as well as rectify conflicts of interest that have arisen because em- 
ployees in the financial sector are measured, evaluated and awarded more on the basis of the number of products sold and services provided than on the customer getting the right product or service at the right price. The main concrete consequences for the NFU and its affiliated organisations of these reforms can be described in the following way. Below is an overview of the work of the NFU concerning the European regulations which include rules on wages in different ways.

\subsubsection{The Capital Requirements Directive 2013/36/EU}

The Capital Requirements Directive (CRD IV), which came into force in January 2014, includes most banking operations, including remuneration policy. Provisions regarding compensation policies are extensive in many areas in the Directive. The NFU worked intensively with the issue and has succeeded in obtaining one exemption (see below) from these provisions when the remuneration levels are determined by a collective agreement:

(69) The provisions on remuneration should be without prejudice to the full exercise of fundamental rights guaranteed by Article 153(5) TFEU, general principles of national contract and labour law, Union and national law regarding shareholders' rights and involvement and the general responsibilities of the management bodies of the institution concerned, and the rights, where applicable, of the social partners to conclude and enforce collective agreements, in accordance with national law and customs.

\subsubsection{Framework 2014/59/EU for the recovery and resolution of credit institutions}

Apart from the fact that initially the Commission completely overlooked bank employees and their considerations when drawing up the proposal, which was serious enough in itself bearing in mind that they constitute one of the core groups affected by the proposed measures, it bordered on what is acceptable in terms of wages. In its proposal, the Commission wished to give the resolution authority the right to approve wage levels at banks and the possibility of writing down the employees' variable wages. This is probably an example of the Commission's above-mentioned lack of knowledge about wages regulated in collective agreements. The NFU emphasised that a vast majority of bank employees have negotiated solutions 
regarding variable wages, which is why these should naturally also be included in the debts that should not be written down. Thanks to the efforts of the NFU, the final version of the Directive includes an exemption for wage levels regulated by collective agreements.

\subsubsection{Directive 2014/65/EU on markets in financial instruments}

In the revised Directive on markets in financial instruments (MiFID 2), rules are introduced to prevent conflicts of interest where the risk of wage incentives is recognised. The NFU claimed that exaggerated sales goals and excessive sales targets, not variable wages, are primarily responsible for increasing the risk of conflicts of interest among employees. A company providing financial services must now act in the best interests of the customer, and an employee may not recommend a certain product or service to a customer if another product or service suits the customer better.

\subsubsection{Revision of Directive 2012/360/2 on insurance mediation}

The revision of the Directive on insurance mediation (IMD 2) aims to enhance transparency and prevent conflicts of interests in order to improve consumer protection and instil trust in the sector. The legislature had not come to an agreement in November 2014 about the exact wording of IMD 2. However, as the proposal stood, it was fairly far-reaching regarding the information that customers would be provided about the insurance mediators' wages. Therefore, the NFU put forward the view that customers should be provided information about whether products are linked to variable wages, but not more detailed information about the individual sales person's salary or identity. In the NFU's view, consumer protection is not increased because a customer is given information on the exact figures for the variable wages of an employee. Instead, there is a risk that this has a detrimental effect and diverts the customer's attention from what should be the focus of a sale: the product's price and contents. Moreover, it is not permitted to violate the integrity of the employees. After all, how an employee is paid, through a fixed or variable salary, is a matter for the employer, the employee and the trade union. 
In the Nordic Area, where wages are regulated through collective agreements, similar rules risk undermining the legitimacy of collective bargaining. Thus, according to the NFU, conflicts of interest are most easily alleviated by dealing with the issue of unreasonable sales goals and stress, not by violating the personal integrity of individual insurance employees regarding their wages.

\subsection{Guidelines issued by the European supervisory authorities}

\subsubsection{CEBS wage guidelines}

The CEBS is now called the European Banking Authority (EBA) and is one of three supervisory bodies in the EU responsible for bank supervision. In 2010, draft guidelines on remuneration were published against the background of the proposed rules in CRD III (the predecessor of the abovementioned CRD IV), which aimed to reduce wage incentives for taking exaggerated risks in banks. Potentially large groups of employees were affected, including employees whose wages are regulated by a collective agreement. After the NFU strongly stressed its views, an exemption for the right of the social partners to regulate wages via collective agreements was included in the final version of the CEBS guidelines.

\subsubsection{The EBA's technical standards on criteria to identify categories of staff whose professional activities have a material impact on an institution's risk profile (EBA/RTS/2013/11)}

The EBA proposed that by giving a wage level in absolute terms, it should be possible to identify employees with an impact on the risk level of the company. During the consultation process, the NFU called attention to the fact that the use of absolute wage figures to identify risk-takers is not a suitable criterion, due to different wage levels in the EU. It would thus be possible to identify different categories of employees in different EU countries. Moreover, the NFU underlined that provisions on remuneration 
should not apply if a collective agreement has been concluded. The same exemption for collective agreements as in CRD IV should have been included in the technical standards of the EBA. With some revision after the consultation process, the final version includes quantitative criteria on wage levels to identify potential risk-takers.

\subsubsection{ESMA's guidelines on sound remuneration policies under the AIFMD (ESMA/2013/201)}

Like the EBA, the ESMA (European Securities and Markets Authority) presents wage levels as a possible way to identify staff who affect the risk profile of a company and who should thus be affected by these guidelines on remuneration policies under the AIFMD (Alternative Investment Fund Managers Directive). The NFU has not worked specifically with the AIFMD, but notes how the EMSA once again believes it has the right to issue guidelines on wage formation.

\subsubsection{ESMA guidelines on remuneration policies and practices (MiFID) (ESMA/2013/606)}

The ESMA was given the task of drawing up detailed guidelines on the basis of the above-mentioned Directive MiFID II which regulates the sale of financial instruments and products in the EU.

In guidelines on remuneration policies related to MiFID, the ESMA seems unaware of the fact that the proposals are a mortal blow to free wage formation. The guidelines include no exemptions for wages negotiated via a collective agreement, or for the fact that, according to Article 153(5) of the Lisbon Treaty, the EU may not create a remuneration policy. The guidelines dictate how remuneration policies should be designed. The NFU reacted forcefully to the proposal which was put forward already in the autumn of 2012 by pointing out the absolute right of the social partners to set wages via an agreement, and wished to impress upon the Commission that it cannot use EMSA's guidelines to encroach upon the statutory right of the social partners to conclude collective agreements. This has evidently been ignored by the EMSA. 


\subsubsection{EIOPA and the drawing up of guidelines on conflicts of interest}

In drawing up the technical guidelines for the implementation of the above-mentioned Insurance Mediation Directive, the EIOPA is also responsible for regulating the prevention and management of conflicts of interests. Apart from the comments put forward by the NFU on information about individual wages and the integrity of the employees, the NFU has also claimed that it is important to highlight systems of goals in general and excessive sales targets, rather than wages. There is a risk of only regulating wage-incentive schemes and not other incentives linked to sales goals that have an impact on the career options of staff.

The NFU's view is that the examples above illustrate a clear trend whereby the EU is becoming increasingly interested in remuneration in the financial sector. Legislation on absolute levels has been discussed, but so far the EU has been satisfied to regulate in different ways how variable wages should be set in relation to the sale of products and the prevention of risks. A few exemptions have been made for wages regulated by collective agreements, and the need for these exemptions indicates a clear change: that the EU has gradually expanded its competence in the area of wage formation and there is a continued threat that the Nordic model will be encroached upon, despite the fact that the right to free wage formation between the social partners is enshrined in the TFEU.

\subsection{What can we expect?}

In the autumn of 2014, the new European Commission under President Jean-Claude Juncker will start its term. What can we expect during the next five years and how will it differ from the previous five years?

The EU's legislative work for the financial sector has been intense since 2008. Everything points to a shift in the EU during the next mandate period, from producing new rules to implementing the ones already created. This is a rather heavy workload, and Jonathan Hill, the new Commissioner for Financial Stability, Financial Services and Capital Markets, judges that the EU's supervisory authorities will need to draw up rules for over 400 detailed areas. As mentioned above, the three supervisory authorities at 
EU level, the EBA, ESMA and EIOPA, have a great deal of power over how the scope of the rules in Directives and Regulations at Framework level (agreements between the Council and the European Parliament) should be understood and implemented in the Member States.

The next challenge can be discerned in relation to the transposition of all the new rules into national legislation. National parliaments and authorities will have to include rules and guidelines from the EU in national legislation. The risks entailed by these processes are considerable from a legal perspective. How, for example, can one ensure that the rules are worded in the same way in different languages and that the scope and thus the legislative preconditions are the same? The NFU has already seen examples of how the national interpretation and translation of new rules in certain cases differ from the intentions and exemptions for trade-union rights that the NFU has secured at EU level. Therefore, it will continue to be important for trade unions to closely follow this work at national level and contribute expert knowledge to ensure the continued freedom of the social partners to regulate wages through agreements. Accordingly, it remains to be seen how the regulatory trend will affect the financial sector, both regarding trade-union rights and the Nordic labour market in general.

Bearing in mind the sheer number of new rules (sixty thousand pages), the EU is also facing a considerable challenge if competitive neutrality and cohesion within the internal market in financial services are to be maintained and reinforced. 


\section{Sammenfatning}

Denne rapport belyser en række af de udfordringer, som de arbejdsretlige systemer i de nordiske lande står over for i mødet med EU, EØS og Den Europæiske Menneskerettighedskonvention. Rapporten fokuserer på de generelle tendenser i de europæiske påvirkninger og den måde, som de er blevet håndteret på i de nordiske lande.

I en generel analyse fremhæver professor, dr. jur. Jens Kristiansen, Københavns Universitet, at de europæiske påvirkninger varierer mellem landene, men at der også er tale om en række fællestræk ved de udfordringer, som de nordiske arbejdsretlige systemer står over for:

Det stadig mere komplekse europæiske retssystem: Alle de nordiske arbejdsretlige systemer indgår i et samspil med et stadig mere uoverskueligt europæisk retssystem. Den europæiske retsudvikling foregår i et kompliceret samspil mellem forskellige typer af retskilder, f.eks. generelle retsprincipper (traktater) og konkrete regler (direktiver). De europæiske regler varetager krydsende hensyn - f.eks. fremme at fri bevægelighed og sikring af faglige grundrettigheder - som de tre europæiske domstole ikke nødvendigvis vil have samme tilgang til. Den komplekse retsdannelse gør det ofte vanskeligt at foretage en præcis fastlæggelse af de europæiske forpligtelser.

Forskydning af den nationale balance mellem lovgivning og overenskomster: Lovgivning har fået en mere fremtrædende rolle i alle de nordiske lande som led i implementeringen af europæiske forpligtelser. Der har dog ikke været tale om grundlæggende forandringer i arbejdsdelingen mellem lovgivningsmagten og arbejdsmarkedets parter, og kollektive overenskomster spiller fortsat en vigtig rolle for fastlæggelsen af løn- og arbejdsvilkår i alle lande. Retten til fri serviceudveksling synes at stille de nordiske systemer over for særlige udfordringer og giver løbende anledning til både politisk debat og principielle retssager.

Domstolenes stigende betydning i det arbejdsretlige system: Domstolene har fået en mere fremtrædende rolle i forhold til både overenskomstpar- 
terne og lovgivningsmagten. Domstolene skal i videst muligt omfang fortolke national ret i overensstemmelse med de europæiske forpligtelser, herunder den dynamiske udvikling af generelle, vage retsprincipper. Domstolene kan også prøve, om nationale regler er forenelige med de europæiske forpligtelser, f.eks. om et lovindgreb i en arbejdskonflikt var "nødvendigt". Det vil løbende indsnævre den politiske handlefrihed og gøre det vanskeligere for arbejdsgivere og lønmodtagere at indrette sig $\mathrm{i}$ tillid til en bestemt forståelse af national ret.

I en række konkrete bidrag belyser praktikere fra arbejdsgiver- og lønmodtagerforeninger nogle af de udfordringer, som arbejdsmarkedets parter i de forskellige nordiske lande oplever i samspillet mellem de europæiske systemer og de nationale arbejdsretlige systemer. Bidragene kredser navnlig om temaer som udstationeret arbejdskraft, implementering af arbejdsretlige direktiver samt den stigende europæiske interesse for de nationale lønpolitikker. 
Nordic Council of Ministers

Ved Stranden 18

DK-1061 Copenhagen K

www.norden.org

\section{Europe and the Nordic Collective-Bargaining Model}

One of the special features of the Nordic countries is that the determination of wages and working conditions is largely left up to the negotiations between the social partners.

The purpose of this report is to illuminate a number of the challenges faced by the labour-law systems of the Nordic countries in the light of an increasingly well-developed European law system.

The first part of the report was prepared by Dr. Jur. Jens Kristiansen, the editor-in-chief, and focuses on a number of the general challenges facing the labour-law systems of the Nordic countries in the form of European rules and court decisions.

The second part of the report was prepared by various representatives of employer and employee organisations in the Nordic countries and illustrates some of the challenges faced by the social partners in their interaction with the European court system and the way in which these challenges have been addressed in the individual countries.

TemaNord 2015:541

ISBN 978-92-893-4177-6 (PRINT)

ISBN 978-92-893-4179-0 (PDF)

ISBN 978-92-893-4178-3 (EPUB)

ISSN 0908-6692

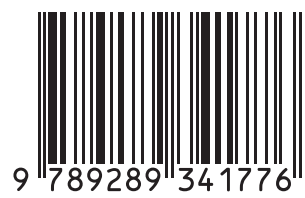

